\title{
Patient Reported Outcomes in Cirrhosis: A Scoping Review of the Literature
}

Elliot B. Tapper (1), Fasiha Kanwal (2-4), Sumeet K. Asrani (5), Chanda Ho (6), Nadia

Ovchinsky (7), John Poterucha (8), Avegail Flores (9), Judith E. Smith (10), Victor Ankoma-Sey

(11), Bruce Luxon (12), Michael Volk (13).

1. Division of Gastroenterology and Hepatology, University of Michigan

2. Section of Gastroenterology and Hepatology, Department of Medicine, Baylor College of Medicine, Houston, TX, USA.

3. Center for Innovations in Quality, Effectiveness and Safety, Michael E. DeBakey Veterans Affairs Medical Center, Houston, TX, USA.

4. Section of Health Services Research, Department of Medicine, Baylor College of Medicine, Houston, TX, USA

5. Division of Hepatology, Baylor University Medical Center, Dallas, TX

6. Division of Gastroenterology, California Pacific Medical Center

7. Division of Pediatric Gastroenterology, Children's Hospital at Montefiore, Bronx, NY

8. Division of Gastroenterology, Mayo School of Medicine

9. Division of Gastroenterology, Washington University School of Medicine, St. Louis, MO

10. Taubman Health Sciences Library, University of Michigan

11. Division of Gastroenterology, Houston Methodist

12. Department of Medicine, Georgetown University

13. Division of Gastroenterology and Transplantation Institute, Loma Linda University, Loma Linda CA

Keywords: Quality of life, Ascites, Hepatic Encephalopathy, Liver Disease, Muscle Cramps

Word count: 2,407

Emails: Tapper (etapper@umich.edu), Asrani (sumeet.asrani@bswhealth.org), Ho (hocc@sutterhealth.org), Kanwal (kanwal@bcm.edu), Volk (mvolk@ilu.edu), Flores (avegailf@gmail.com), Poterucha (poterucha.john@mayo.edu), Ovchinsky (novchinsky@yahoo.com), Luxon (bruce.a.luxon@gunet.georgetown.edu), Ankoma-Sey (akobot@aol.com), Smith (judsmith@umich.edu)

Corresponding author:

Michael L. Volk, MD, MSc

Division of Gastroenterology/Hepatology and Transplantation Institute

Loma Linda University Health, Loma Linda CA

mvolk@1lu.edu

Disclosure:

1. Roles

a. Concept: AASLD Practice Metrics Committee

b. Analysis: AASLD Practice Metrics Committee

c. Data acquisition: AASLD Practice Metrics Committee

This is the author manuscript accepted for publication and has undergone full peer review but has not been through the copyediting, typesetting, pagination and proofreading process, which may lead to differences between this version and the Version of record. Please cite this article as doi:10.1002/ hep.29756. 
d. Writing: Tapper, Kanwal, Volk

e. Critical revision: AASLD Practice Metrics Committee

2. Conflicts of interest: No author has any conflicts of interest to declare

3. Funding: Elliot Tapper receives funding from the National Institutes of Health through the Michigan Institute for Clinical and Health Research (KL2TR002241).

Abbreviations:

health related quality of life (HRQOL)

patient reported outcomes (PROs)
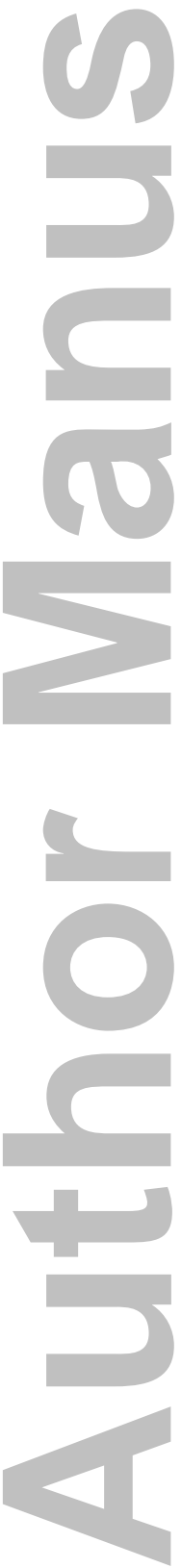


\section{Abstract}

Patients with cirrhosis seek improvement in their symptoms, functioning, quality of life, and satisfaction with the care they receive. However, these patient reported outcomes (PROs) are not routinely measured for clinical care, research, or quality improvement. The members of the American Association for the Study of Liver Disease Practice Metrics Committee, charged with developing quality indicators for clinical practice, performed a scoping review of PROs in cirrhosis. The aim is to synthesize a comprehensive set of PROs for inclusion into a standard patient-centered outcome set. We searched Medline, EMBASE, CINAHL, PsycINFO, and the Cochrane Trial Library since inception, with final searches run between 4/20/2017-6/1/2017. Studies were included if they reported the construction and/or validation of a PRO instrument for patients with cirrhosis or if they assessed the clinical (case mix) variables determining responses to established PRO scales.). Eleven studies were selected that yielded 259 items specific to patients with cirrhosis. After removing duplicates, 152 unique items were isolated. These items were consolidated into 7 domains: physical symptoms, physical function, mental health, general function, cognition, social life, and satisfaction with care. The 7 domains included 52 subdomains (e.g.,physical domain; abdominal pain subdomain). Twelve variables were identified that independently modified established PRO scales. These included clinical factors (severity of liver disease and its complications, medication burden, and comorbidities), specific PROs (cramps, pruritis), and surrogate outcome measures (falls, hospitalization).

Conclusion: This scoping review identified and categorized a large existing set of PRO concepts that matter to patients with cirrhosis. These outcomes may now be translated into usable measures for both the assessment of the quality of cirrhosis care in clinical practice and to perform research from the patient's perspective. 


\section{Introduction}

The prevalence of cirrhosis in the US has almost doubled in the last decade, resulting in a substantial rise in its associated morbidity and mortality. $(1,2)$ As many as half of patients with cirrhosis develop clinical complications, including variceal hemorrhage, ascites, hepatic encephalopathy (HE), and hepatocellular carcinoma. The health burden of cirrhosis is amplified by its dramatic impact on patients' health related quality of life (HRQOL), resulting from a range of physical, psychological, and social stressors engendered by cirrhosis and its treatment.

Ensuring that patients with serious illness receive patient-centered care is a fundamental goal of medical care. For this care to be patient-centered, it must be aligned with what matters to the patients. Despite the realization that patient-reported outcomes (PROs) are important to patients, current quality improvement efforts rarely assess PROs. One explanation underlying this disconnect is lack of standardized PROs that may serve as benchmarks for quality measurement and improvement in cirrhosis.

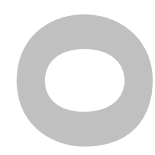

To address this gap, and under the auspices of the Practice Metrics Committee of the American Association for the Study of Liver Disease, we conducted a scoping review of PROs in cirrhosis. Our goal was to identify and summarize the PRO domains that may serve as candidates for a set of outcomes as part of quality improvement efforts in cirrhosis. 


\section{Methods}

We performed a scoping review. A scoping review is a variant of systematic review which aims to identify and map key concepts with a large body of evidence.(3) The scoping review methodology can be more appropriate than a systematic review when the body of literature is large, complex, heterogeneous and without a prior comprehensive review.(4) We hypothesized that the literature would already contain significant information about PROs relevant to cirrhosis, but the manuscripts may not be explicitly labeled as such.

\section{Search Strategy}

With the aid of an informationist with expertise in scoping reviews (JS) we searched six databases: Medline (OVID), Cumulative Index to Nursing and Allied Health Literature, Embase, PsycINFO, and Cochrane Library. No date restrictions were applied, and final searches were conducted between April 20, 2017 and June 1, 2017. The search strategy for each database is provided in a Technical Supplement. Searches combined a block of terms specific to disease (i.e., cirrhosis and its complications, as well as each liver disease enumerated) with terminology specific to PROs (e.g. patient reported measures, quality of life, and patient satisfaction) and with names of published PRO instruments used in liver disease (e.g., SF-36) abstracted from a prior systematic review.(5). Sentinel articles were used to validate the search strategy and provide additional references through looking at reference lists and conducting citation tracking searches through the database SCOPUS. Articles meeting inclusion criteria were also used to citation track using Scopus. 


\section{Study Selection}

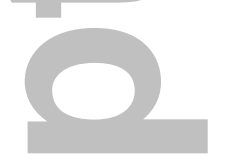

Studies were included if they reported the construction/validation of a PRO instrument for patients with cirrhosis or if they assessed the clinical variables that determined responses to established PRO scales and reported granular data specific domains/responses within the scales. As above, we defined PRO as patients' own assessment of their health status including symptoms, reports of daily functioning, quality of life and satisfaction with healthcare. For example, if a study on quality of life provided details on these domains it was included, but if it only reported summary scores from a previously developed instrument (such as Short Form-36; SF-36) then it was excluded.

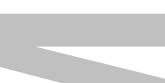

We only included English language publications. We excluded studies focusing on liver transplant, including those pertaining to patients awaiting liver transplant or recollecting their condition prior to transplantation. We also excluded studies of children, patients with acute liver failure, and non-cirrhotic chronic liver disease (including treatment for hepatitis C), hepatocellular carcinoma, and studies that focused on pre- or post-liver transplant experiences.



Seven reviewers independently screened titles and abstracts for eligibility. Each title was reviewed by at least 2 reviewers. The papers excluded by title, abstract and after full-text review were recorded. Each reviewer selected the full text studies they judged as relevant or unclear. These studies were included in a final grouping where selection conflicts between the two index 
reviewers were further adjudicated by two arbitrators (EBT and MV) where unresolved conflicts were settled by a third arbitrator (FK).

Data extraction and analysis

Included studies were summarized according to their population, aims, methods and key findings. All survey items and determinants of PRO responses were aggregated and categorized by two reviewers (authors EBT, MV). Verbatim duplicates were excluded. Discrepancies with respect to inclusion and categorization were adjudicated by a third review (author FK).
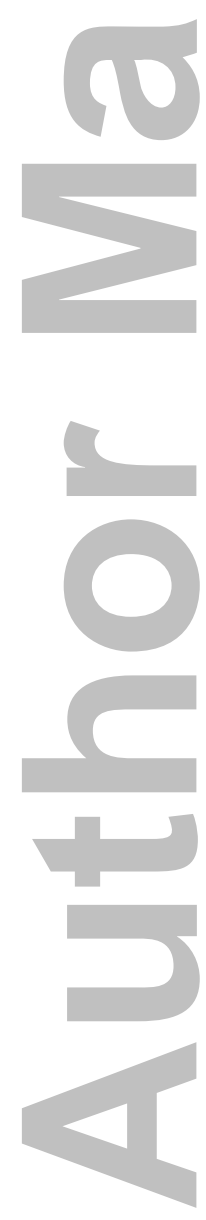


\section{Results \\ Population Characteristics in Included Studies}

Of 5,647 studies screened, 11 studies met our inclusion criteria (Figure 1). For a description of the included studies, see Table 1 . Of these 11 studies, 4 were from the US,(6-9) 2 from Denmark,(10,11) and 1 each from China, Taiwan, Japan, Spain, and Italy.(12-16) Overall, these studies enrolled 2,299 (range 11-544) patients. The stage of liver disease was available for 1,550 (67\%), of whom 586 (38\%) were Child A and 964 (62\%) were Child B-C. Granular details of cirrhosis etiology were available for 1,268 (55\%) patients, of whom $643(51 \%)$ had viral hepatitis and $360(28 \%)$ had alcoholic liver disease.

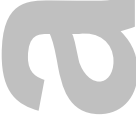

Description of Study Aims and Methods (Table 1)

Health-related quality of life (HRQOL) or PRO scale development:

Four studies - by Younossi, Gralnek, Onishi, and Zhang - aimed to create disease-specific scales. Three of these studies only included patients with cirrhosis. The fourth study included patients with as well as those without cirrhosis; however, the majority (66\%) had cirrhosis in this study.(7, 9, 14, 16) One study (Onishi(14)) focused exclusively on patients with ascites. Each study utilized a deliberate, stepwise approach to determine the pertinent domains and questions; these included semi-structured patient interviews to develop themes, separate interviews to narrow and refine the questions, and an evaluative cohort to demonstrate final results which included an assessment of responsiveness to therapy. 


\section{Qualitative analysis:}

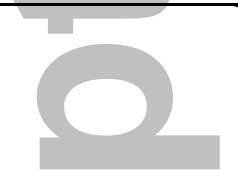

Four studies described the results of qualitative analyses where patients were asked open ended questions about their experiences. In 3 cases, these were performed in focus groups with semi-structured interviews. Tsai interviewed patients and asked them to rank-order the most important physical and psychological components of cirrhosis.(12) Over the course of two papers, $(10,11)$ Mikkelsen described the results of patient interviews focusing on the conditions that limit or support coping with physical and psychological problems before and after a grouptherapy intervention. Vaughn mailed surveys with questions and opportunities for free-text responses to capture the rate and impact of feelings of stigma.(8)

Impact of clinical variables on PRO domains:

Cross-sectional survey studies by Marchesini, Chatrath, and Roman evaluated the impact of clinical variables on domains of established PRO scales including the Chronic Liver Disease Questionnaire, Short Form-36 and Nottingham Health Profile, respectively.(6, 13, 15) Roman was specifically interested in the impact of falls and cognitive dysfunction and Chatrath focused exclusively on the impact of muscle cramps. Marchesini explored several clinical variables and used regression techniques to determine the factors independently associated with suboptimal PROs.

Categorized Study Findings 
Overall, the 11 studies yielded 259 items specific to patients with cirrhosis. After removing duplicates, 152 unique items were isolated (Supplementary Table). Each could be categorized into one of 7 broader domains (physical symptoms, physical function, mental health, general function, cognition, social life, and satisfaction with care) as well as 52 sub-

domains.(Figure 2) The physical health domain had the most sub-domains (e.g. abdominal pain, appearance, dizziness). Examples of the mental health domain included depression and alcohol abuse, the function domain included items regarding career and daily activities, the social life domain dealt with stigma and isolation, the satisfaction with care domain touched on items relating to medication side effect concerns and the quality of the patient-doctor relationship, and, finally, the cognition domain included items on concentration and forgetfulness among others In many cases, multiple items referred to the same sub-domain, e.g. multiple questions covered material pertinent to abdominal pain, bloating and sexual function. There were many ways of asking about, for example, the abdominal pain or itching sub-domains of physical health. In the Supplementary Table, we provide representative example items for each subdomain, e.g. "I was annoyed at abdominal pain and indigestion" (abdominal pain from Zhang et al(16)) or "How much have you been troubled by itching during the last two weeks?" (pruritis from Younossi et $\operatorname{al}(5))$.

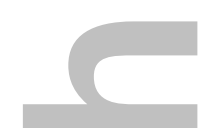

Multiple studies evaluated whether specific variables were associated with significant differences in the scores of PRO scales such as the SF-36, Nottingham Health Profile, and Chronic Liver Disease Questionnaire.(Table 3) Twelve variables were identified based on the review of these studies. These included clinical factors (etiology and severity of liver disease, 
cognitive dysfunction and hepatic encephalopathy, ascites, comorbidities, medication burden, loop diuretics, hospitalization), and patient reported symptoms (cramps, pruritis, falls)

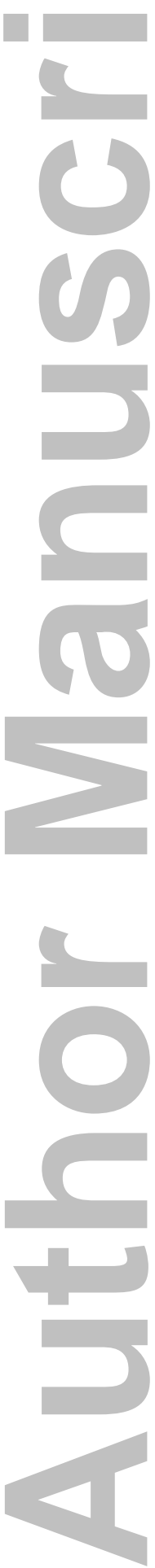

Hepatology

This article is protected by copyright. All rights reserved. 


\section{Discussion}

In this scoping review, we systematically identified 152 distinct PROs reported by patients with cirrhosis. We then distilled them into a set of 7 major domains and 52 subdomains. These data from 11 studies reflect the experiences of 2,299 patients from 7 countries across the spectrum of disease etiology and severity. Whereas any one study's results may not generalize to another context, this scoping review provides a comprehensive list of patient reported outcomes that are applicable to most patients with cirrhosis seen in different health care settings.



These data extend the literature on PROs in cirrhosis in 2 principle ways. First, our goal was to identify a broad range of PROs that matter to our patients. Many disease-specific HRQOL instruments (e.g. Chronic Liver Disease Questionnaire(9) and Liver Disease Quality of Life(7)) have already been developed for patients with cirrhosis. Other non-specific tools, such as the Patient-Reported Outcomes Measurement Information System, have been validated in cirrhotic populations.(17) Indeed (and not surprisingly) the broader domains that we identified map well with the domains in existing HRQOL instruments. Our review also found many additional items and sub-domains that were not included in previous HRQOL tools. Whereas HRQOL instruments reliably capture the patient's values, preferences, and response to therapeutic interventions, they do not necessarily speak to other PRO domains such as symptom status, function, satisfaction with care or adherence to medication.(18) Furthermore, in contrast to the development of psychometric indices, for the purpose of Quality Improvement it is important to identify measures that are sufficiently granular to inform specific therapeutic needs 
(i.e. as relates to frailty or sexual dysfunction) and are responsive to therapeutic interventions (such as control of ascites).

Second, our review also identified 12 variables that had statistically significant and clinically meaningful impact on established HRQOL scales. Although some of these factors were PROs (pruritis, cramps), most were clinician reported features of cirrhosis that significantly impacted PROs. The latter may either serve as surrogate outcome measures (such as falls, hospitalization) or variables for case-mix risk adjustment of PROs (such as the etiology of liver disease and the presence of comorbid conditions).

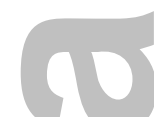

To build on this study, we suggest two next steps. One, these PROs can serve as important measures for clinical care that many physicians may want to explore with their patients. Answers to many questions that may often go unasked, about, for example, falls, pruritis, or sexual function each have the capacity to modify clinical management in meaningful ways. Two, these PROs will serve as potential candidates for outcome based quality measures. These items will serve as candidate outcome measures for an upcoming 2-round modified Delphi panel process for ranking and selection by a group of content experts. Thereafter, a specification process will follow to convert these findings into discrete measures with clear numerators, denominators, and denominator exclusions, that can be implemented into clinical care and followed longitudinally. A similar PRO identification process was recently employed by the International Consortium for Health Outcomes Measurement group.(19, 20) As this group has identified, new reporting standards may increase the demands for data collection on frontline 
providers. Implementation is an unresolved challenge for the growing experience with PRO sets. (19-21) In addition to the work of PRO identification, implementation efforts designed with sensitivity to clinician workflow are necessary. The optimal quality measure is clinically meaningful, standardized and easily measured while neither overburdening the frontline clinician (and patient) nor increasing the costs of healthcare delivery. Realizing the goal of integrating a set of PRO assessments in routine clinical practice will require designing items with responses that are easily abstracted from existing data and leveraging the functionality of electronic health records. In Figure 3, we summarize the work to date and outline the remaining steps needed to achieve our goals.

These data must be interpreted in the context of the study design. First, given the inclusion criteria for the selected studies, these data apply to pre-transplant adult patients with cirrhosis; generalizability to post-transplant or pediatric patients is unclear. Second, the list of 52 sub-domains may be reduced further if some factors are found to be duplicative or equivalent by patients. For example, the term "bleeding episodes" may suffice for hematemesis, melena, and epistaxis. Third, the relative importance of specific domains is certain to change with the patient's clinical context. The patient with Child A cirrhosis may benefit from surveys that focus on specific domains and sub-domains such as mental health (sexual function, alcohol, and stigma) whereas those with Child C may need to be asked different questions (such as adherence, isolation, and caregiver burden). 


\section{Conclusion}

The symptoms and preferences expressed by patients with cirrhosis are equal in importance to their clinical outcomes. Well defined quality indicators based on processes of care have been defined to facilitate improved clinical outcomes. Similar indicators are lacking for PROs. This scoping review identified a large existing set of PRO concepts, which may now be translated into usable measures to support quality improvement in cirrhosis.
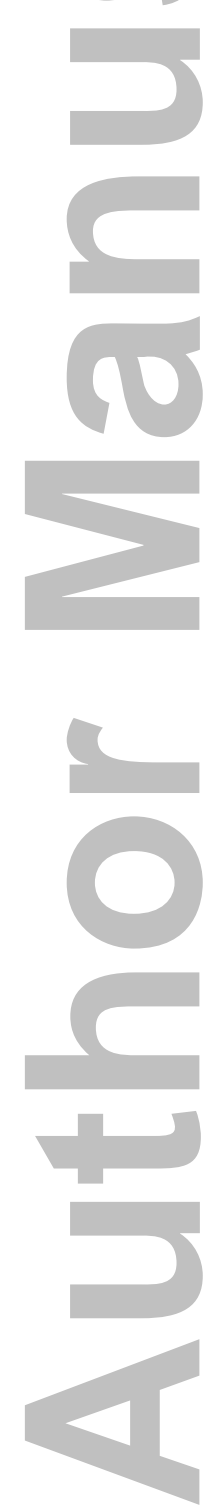
Figure 1: Flow Diagram of Study Selection

Figure 2: Domains and Sub-domains of Patient Reported Outcomes in Cirrhosis

Figure 3: Overview of the Process Translating Patient Reported Outcomes (PROs) into Quality Measures

The goal of Practice Metrics Committee of the American Association for the Study of Liver Disease is to create a registry that tracks clinical and patient reported outcomes. To achieve this goal, the committee is developing a platform that allows for the integration of clinical data (e.g. etiology, disease severity, and comorbid illnesses) with PROs obtained during a clinical visit in the Electronic Health Record (EHR). The work described in this paper is the crucial first step where the key PROs for patients with cirrhosis have been collected from the literature. Our next step is to refine and specify the PROs (i.e. how they will be measured) during patient focus groups and a modified Delphi-process with expert hepatologists.

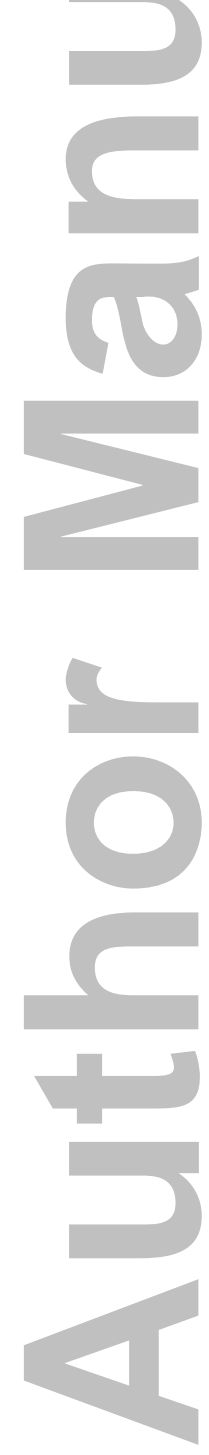


Table 1: Characteristics of Included Studies

\begin{tabular}{|c|c|c|c|c|}
\hline $\begin{array}{l}\text { Author } \\
\text { (Year) }\end{array}$ & $\begin{array}{l}\text { Population } \\
\text { Evaluated }\end{array}$ & Aims & Method & Key findings \\
\hline $\begin{array}{c}\text { Younossi } \\
1999\end{array}$ & $\begin{array}{c}133 \text { Ambulatory } \\
\text { patients, CTP A } \\
(32 \%), \text { CTP B }(23 \%) \text {, } \\
\text { CTP C }(11 \%), \text { no } \\
\text { cirrhosis }(34 \%) \text {. } \\
\text { Cholestatic disease } \\
(23 \%), \\
\text { 'hepatocellular' } \\
(77 \%)\end{array}$ & $\begin{array}{l}\text { Develop disease- } \\
\text { specific HRQOL } \\
\text { instrument }\end{array}$ & $\begin{array}{l}\text { Semi-structured interviews } \\
\text { to select } 156 \text { candidate } \\
\text { instrument items in cohort } \\
\text { of } 60 \text { patients. } \\
\text { Determined importance of } \\
\text { each item in separate cohort } \\
\text { of } 75 \text { patients for reduction } \\
\text { to } 29 \text { items. }\end{array}$ & $\begin{array}{l}\text { Identified } 6 \text { domains: } \\
\text { abdominal symptoms, fatigue, } \\
\text { systemic symptoms, activity, } \\
\text { emotional function, and worry. } \\
\text { Scores worsen with CTP class. }\end{array}$ \\
\hline $\begin{array}{c}\text { Gralnek } \\
2000\end{array}$ & $\begin{array}{c}221 \text { ambulatory } \\
\text { patients } \\
\text { CTP A }(29 \%), \text { B } \\
(52 \%), \text { C }(19 \%) \\
\text { Viral }(51 \%), \text { Alcohol } \\
(16 \%), \text { Cholestatic } \\
(12 \%)\end{array}$ & $\begin{array}{l}\text { Develop disease- } \\
\text { specific HRQOL } \\
\text { instrument }\end{array}$ & $\begin{array}{l}\text { Semi-structured interviews. } \\
\text { Psychometric analysis. } \\
\text { Content validation. }\end{array}$ & $\begin{array}{c}36 \text { items detailing activity of } \\
\text { daily } \\
\text { living, concentration, memory, } \\
\text { sexual functioning, sleep, } \\
\text { loneliness, hopelessness, } \\
\text { quality of social interaction, } \\
\text { health distress, and self- } \\
\text { perceived stigma. }\end{array}$ \\
\hline $\begin{array}{c}\text { Marchesini } \\
2001\end{array}$ & $\begin{array}{c}544 \text { patients } \\
\text { (ambulatory and } \\
\text { admitted) } \\
\text { CTP A (38\%), B } \\
(38 \%), \text { C }(24 \%) . \\
\text { Viral }(64 \%), \text { alcohol } \\
(29 \%) .\end{array}$ & $\begin{array}{l}\text { Determine clinical } \\
\text { variables } \\
\text { associated with } \\
\text { HRQOL } \\
\text { (SF-36 and NHP) }\end{array}$ & $\begin{array}{l}\text { Cross-sectional survey } \\
\text { responses. } \\
\text { Results compared to age- } \\
\text { and sex-matched healthy } \\
\text { controls }\end{array}$ & $\begin{array}{c}\text { The two most important } \\
\text { clinical variables associated } \\
\text { with HRQOL were CTP and } \\
\text { muscle cramps. The presence } \\
\text { of HE, pruritus, ascites, } \\
\text { diuretics, hospitalization, and } \\
\text { comorbidities affected HRQOL } \\
\text { subscales. }\end{array}$ \\
\hline $\begin{array}{c}\text { Chatrath } \\
2012\end{array}$ & $\begin{array}{c}150 \text { ambulatory } \\
\text { patients. CTP A } \\
(29 \%) \text {, CTP B }(47 \%), \\
\text { CTP C }(24 \%) . \text { Viral } \\
(42 \%), \text { Alcohol } \\
(22 \%)\end{array}$ & $\begin{array}{l}\text { Determine impact } \\
\text { of cramps on } \\
\text { HRQOL (using } \\
\text { CLDQ) }\end{array}$ & $\begin{array}{l}\text { Cross-sectional survey } \\
\text { responses and clinical } \\
\text { assessment }\end{array}$ & $\begin{array}{l}\text { Cramp severity correlates with } \\
\text { CLDQ score. Cramps } \\
\text { associated with worse scores in } \\
\text { all CLDQ subscales but worry. }\end{array}$ \\
\hline Tsai 2012 & $\begin{array}{c}49 \text { hospitalized } \\
\text { patients. CTP A } \\
(6 \%) \text {, CTP B }(43 \%), \\
\text { CTP C }(51 \%) \\
\text { Alcohol }(59 \%), \text { viral } \\
(35 \%)\end{array}$ & $\begin{array}{l}\text { Determine } \\
\text { frequency of } \\
\text { physical and } \\
\text { psychological } \\
\text { symptoms }\end{array}$ & $\begin{array}{l}\text { Semi-structured interviews. } \\
\text { Rank ordering by } \\
\text { frequency. } \\
\text { Content validation. }\end{array}$ & $\begin{array}{l}\text { Physical and psychological } \\
\text { symptoms are highly } \\
\text { correlated. Abdominal } \\
\text { symptoms and worry were the } \\
\text { most severe physical and } \\
\text { psychological domains, } \\
\text { respectively. }\end{array}$ \\
\hline Roman 2013 & $\begin{array}{c}118 \text { ambulatory } \\
\text { patients. CTP A } \\
(62 \%), \text { CTP B }(34 \%), \\
\text { CTP C (4\%). Alcohol } \\
(62 \%), \text { Viral }(36 \%)\end{array}$ & $\begin{array}{l}\text { Determine } \\
\text { relationship } \\
\text { between falls and } \\
\text { HRQOL } \\
\text { (using SF-36) }\end{array}$ & $\begin{array}{l}\text { Cross-sectional survey } \\
\text { responses and clinical } \\
\text { assessment for cognitive } \\
\text { dysfunction. }\end{array}$ & $\begin{array}{c}\text { Physical components of } \\
\text { HRQOL are most associated } \\
\text { with cognitive dysfunction and } \\
\text { hyponatremia. Mental } \\
\text { components of HRQOL are } \\
\text { most associated with falls }\end{array}$ \\
\hline Vaughn 2014 & $\begin{array}{c}149 \text { ambulatory } \\
\text { patients. CTP A } \\
(58 \%), \text { CTP B }(36 \%), \\
\text { CTP }(5 \%) \text {. Viral } \\
(34 \%), \text { Alcohol } \\
(12 \%)\end{array}$ & $\begin{array}{l}\text { Determine } \\
\text { prevalence and } \\
\text { impact of stigma }\end{array}$ & $\begin{array}{l}\text { Cross-sectional survey } \\
\text { responses to questions on } \\
\text { stigma abstracted from } \\
\text { multiple surveys with } \\
\text { opportunity for free-text } \\
\text { response. }\end{array}$ & $\begin{array}{l}\text { Stigma is associated with lower } \\
\text { QOL, depression, lower } \\
\text { likelihood of seeking medical } \\
\text { care, and less social support. }\end{array}$ \\
\hline
\end{tabular}




\begin{tabular}{|c|c|c|c|c|}
\hline Onishi 2014 & $\begin{array}{c}175 \text { ambulatory } \\
\text { patients evaluated } \\
\text { before and after } \\
\text { ascites therapy. CTP } \\
\text { A }(12 \%) \text {, CTP B } \\
(50 \%), \text { CTP C }(38 \%)\end{array}$ & $\begin{array}{l}\text { Develop ascites } \\
\text { specific symptom } \\
\text { scale }\end{array}$ & $\begin{array}{l}\text { Semi-structured interviews } \\
\text { with psychometric analysis. } \\
\text { Longitudinal assessment for } \\
\text { changes following } \\
\text { treatment. }\end{array}$ & $\begin{array}{l}\text { Seven question scale that } \\
\text { correlates with severity of } \\
\text { ascites, SF- } 36 \text { scores, and } \\
\text { response to treatment. }\end{array}$ \\
\hline $\begin{array}{c}\text { Mikkelsen } \\
2015,2016\end{array}$ & $\begin{array}{l}11 \text { ambulatory } \\
\text { patients with } \\
\text { alcoholic cirrhosis } \\
\text { and hepatic } \\
\text { encephalopathy }\end{array}$ & $\begin{array}{l}\text { To identify } \\
\text { conditions that } \\
\text { limit or support } \\
\text { coping with } \\
\text { physical and } \\
\text { psychological } \\
\text { problems }\end{array}$ & $\begin{array}{l}\text { Semi-structured interviews } \\
\text { before and after a coping } \\
\text { and physical activity group } \\
\text { intervention }\end{array}$ & $\begin{array}{l}\text { Patients feel responsible to and } \\
\text { seek acknowledgement/positive } \\
\text { attitudes from their clinicians, } \\
\text { find it difficult to seek help for } \\
\text { alcohol relapse. The } \\
\text { intervention improves patient } \\
\text { assessments of self-control, } \\
\text { community and strength. }\end{array}$ \\
\hline Zhang 2016 & $\begin{array}{l}464 \text { ambulatory } \\
\text { patients, unknown } \\
\text { CTP and etiology }\end{array}$ & $\begin{array}{l}\text { To develop the } \\
\text { LC-PROM, a } \\
\text { cirrhosis-specific } \\
\text { PRO scale that } \\
\text { addresses all } \\
\text { physical } \\
\text { symptoms, } \\
\text { psychological } \\
\text { feelings, daily } \\
\text { activities, and } \\
\text { therapeutic status. }\end{array}$ & $\begin{array}{l}\text { Semi-structured interviews } \\
\text { with } 10 \text { patients followed } \\
\text { by item refinement by } \\
\text { another } 10 \text { patients. Item } \\
\text { reduction performed in a } \\
\text { sample of } 200 \text { subjects ( } 150 \\
\text { with cirrhosis). Test } \\
\text { performance in } 464 \text { patients } \\
\text { with cirrhosis and } 112 \\
\text { controls. }\end{array}$ & $\begin{array}{c}\text { The LC-PROM consists of } 55 \\
\text { items which include questions } \\
\text { to obtain information about } \\
\text { treatment satisfaction, } \\
\text { compliance and drug side } \\
\text { effects. }\end{array}$ \\
\hline
\end{tabular}

CLDQ $=$ Chronic Liver Disease Questionnaire, $C T P=$ Child-Turcotte-Pugh, HRQOL $=$ health related quality of life, LC-PROM = Liver Cirrhosis Patient Reported Outcome Measure, NHP = Nottingham Health Profile, PRO = patient reported outcomes, QOL = quality of life, SF-36 = Short-Form-36




Table 2: Domains of Established Health-Related Quality of Life Scales Impacted by Clinical Variables

\begin{tabular}{|c|c|c|c|c|c|c|c|c|c|c|c|c|c|}
\hline \multirow[b]{2}{*}{$\begin{array}{l}\text { Scale / } \\
\text { Study }\end{array}$} & \multirow{2}{*}{$\begin{array}{c}\text { Domains } \\
\text { affected by } \\
\text { Clinical } \\
\text { Variables }\end{array}$} & \multicolumn{12}{|c|}{ Clinical Variables } \\
\hline & & Ascites & $\begin{array}{c}\text { Co- } \\
\text { morbidity }\end{array}$ & $\begin{array}{c}\text { Severity } \\
\text { of } \\
\text { disease }\end{array}$ & $\begin{array}{c}\text { Cognitive } \\
\text { Dys- } \\
\text { function }\end{array}$ & $\begin{array}{c}\text { Pill } \\
\text { Burden }\end{array}$ & $\begin{array}{l}\text { Disease } \\
\text { Etiology }\end{array}$ & Falls & $\begin{array}{l}\text { Hospital } \\
\text { Admits }\end{array}$ & HE & $\begin{array}{l}\text { Loop } \\
\text { Diuretic }\end{array}$ & $\begin{array}{l}\text { Muscle } \\
\text { Cramps }\end{array}$ & Pruritis \\
\hline \multirow{8}{*}{ SF-36 } & General health & - & - & - & - & - & & - & - & - & - & - & - \\
\hline & Vitality & $\bullet$ & - & $\bullet$ & $\bullet$ & - & & $\bullet$ & - & $\bullet$ & $\bullet$ & $\bullet$ & $\bullet$ \\
\hline & Physical roles & $\bullet$ & - & $\bullet$ & $\bullet$ & $\bullet$ & & $\bullet$ & $\bullet$ & $\bullet$ & $\bullet$ & $\bullet$ & $\bullet$ \\
\hline & Physical functioning & $\bullet$ & - & $\bullet$ & $\bullet$ & $\bullet$ & & $\bullet$ & $\bullet$ & $\bullet$ & $\bullet$ & $\bullet$ & $\bullet$ \\
\hline & Emotional roles & $\bullet$ & - & - & $\bullet$ & $\bullet$ & & $\bullet$ & - & $\bullet$ & $\bullet$ & $\bullet$ & $\bullet$ \\
\hline & Mental health & $\bullet$ & - & - & $\bullet$ & - & & - & - & - & - & - & - \\
\hline & Social Functioning & - & - &  & - & - & & - & - & - & - & - & - \\
\hline & Bodily pain & $\bullet$ & - & - & - & $\bullet$ & & - & $\bullet$ & - & $\bullet$ & $\bullet$ & - \\
\hline \multirow{6}{*}{ NHP } & Energy & $\bullet$ & - & $\bullet$ & & $\bullet$ & & & $\bullet$ & $\bullet$ & - & $\bullet$ & $\bullet$ \\
\hline & Sleep & $\bullet$ & - & - & & - & & & - & $\bullet$ & - & $\bullet$ & $\bullet$ \\
\hline & Pain & - & - & - & & $\bullet$ & & & - & - & - & $\bullet$ & $\bullet$ \\
\hline & Emotional Reactions & $\bullet$ & $\bullet$ & - & & - & & & - & - & - & $\bullet$ & $\bullet$ \\
\hline & Social Isolation & $\bullet$ & $\bullet$ & - & & - & & & - & - & - & $\bullet$ & $\bullet$ \\
\hline & Physical Mobility & $\bullet$ & $\bullet$ & - & & $\bullet$ & & & $\bullet$ & $\bullet$ & - & - & $\bullet$ \\
\hline \multirow{5}{*}{ CLDQ } & Fatigue & & & & & & & & & & & $\bullet$ & \\
\hline & Activity & & & & & & & & & & & $\bullet$ & \\
\hline & Systemic Symptoms & & & & & & & & & & & - & \\
\hline & $\begin{array}{c}\text { Abdominal } \\
\text { Symptoms }\end{array}$ & & & & & & & & & & & $\bullet$ & \\
\hline & Emotional Function & & & & & & & & & & & $\bullet$ & \\
\hline Vaughn & Stigma & & & & & & - & & & & & $\bullet$ & \\
\hline
\end{tabular}

CLDQ $=$ Chronic Liver Disease Questionnaire, HE $=$ Hepatic Encephalopathy, NHP $=$ Nottingham Health Profile, SF-36 $=$ Shortform-36. (•) indicates a statistically significant association, (-) indicates the lack of an association. A shaded box indicates that the impact of these variables were not assessed for that particular scale/study. 


\section{(1) \\ References}

1. Beste LA, Leipertz SL, Green PK, Dominitz JA, Ross D, loannou GN. Trends in burden of cirrhosis and hepatocellular carcinoma by underlying liver disease in US veterans, 2001-2013. Gastroenterology 2015;149:1471-1482 e1475; quiz e1417-1478.

2. D'Amico G, Garcia-Tsao G, Pagliaro L. Natural history and prognostic indicators of survival in cirrhosis: a systematic review of 118 studies. J Hepatol 2006;44:217-231.

3. Arksey H, O'Malley L. Scoping studies: towards a methodological framework. International journal of social research methodology 2005;8:19-32.

4. Peters MD, Godfrey CM, Khalil H, Mclnerney P, Parker D, Soares CB. Guidance for conducting systematic scoping reviews. International journal of evidence-based healthcare 2015;13:141-146.

5. Younossi Z, Henry L. Systematic review: patient-reported outcomes in chronic hepatitis C-the impact of liver disease and new treatment regimens. Alimentary pharmacology \& therapeutics 2015;41:497-520.

6. Chatrath H, Ghabril M, Tandra S, Liangpunsakul S, Lacerda MA, Vinayek R, Yoo HY, et al. Prevalence and morbidity associated with muscle cramps in patients with cirrhosis. Gastroenterology 2011;140:S956.

7. Gralnek IM, Hays RD, Kilbourne A, Rosen HR, Keeffe EB, Artinian L, Kim S, et al. Development and evaluation of the Liver Disease Quality of Life instrument in persons with advanced, chronic liver disease--the LDQOL 1.0. American Journal of Gastroenterology 2000;95:3552-3565.

8. Vaughn-Sandler V, Sherman C, Aronsohn A, Volk ML. Consequences of perceived stigma among patients with cirrhosis. Digestive Diseases \& Sciences 2014;59:681-686.

9. Younossi ZM, Guyatt G, Kiwi M, Boparai N, King D. Development of a disease specific questionnaire to measure health related quality of life in patients with chronic liver disease. Gut 1999;45:295-300.

10. Mikkelsen MR, Hendriksen C, Schiodt FV, Rydahl-Hansen S. Coping and rehabilitation in alcoholic liver disease patients after hepatic encephalopathy--in interaction with professionals and relatives. Journal of Clinical Nursing 2015;24:3627-3637.

11. Mikkelsen MR, Hendriksen C, Schiodt FV, Rydahl-Hansen S. Alcoholic liver disease patients' perspective of a coping and physical activity-oriented rehabilitation intervention after hepatic encephalopathy. Journal of Clinical Nursing 2016;25:2457-2467.

12. Li-Hung T, Chang-Ming L, Shu-Chen C, Chia-Ling C, Su-Jane L, Lai-Chu S. Symptoms and Distress Among Patients With Liver Cirrhosis but Without Hepatocellular Carcinoma in Taiwan. Gastroenterology Nursing 2014;37:49-59.

13. Marchesini G, Bianchi G, Amodio P, Salerno F, Merli M, Panella C, Loguercio C, et al. Factors associated with poor health-related quality of life of patients with cirrhosis. Gastroenterology 2001;120:170-178.

14. Onishi Y, Wakita T, Fukuhara S, Noguchi Y, Okada M, Sakaida I, Sasaki Y, et al. Development and validation of a symptom scale specific for ascites accompanied with cirrhosis: The ASI-7. Clinical and translational gastroenterology 2014;5:e48.

15. Román E, Córdoba J, Torrens M, Guarner C, Soriano G. Falls and cognitive dysfunction impair health-related quality of life in patients with cirrhosis. European Journal of Gastroenterology \& Hepatology 2013;25:77-84.

16. Ying Z, Yuanyuan Y, Jing L, Yanbo Z, Zhang Y, Yang Y, Lv J, et al. LC-PROM: Validation of a patient reported outcomes measure for liver cirrhosis patients. Health \& Quality of Life Outcomes 2016;14:1-16. 
17. Bajaj J, Thacker L, Wade J, Sanyal A, Heuman D, Sterling R, Gibson D, et al. PROMIS computerised adaptive tests are dynamic instruments to measure health-related quality of life in patients with cirrhosis. Alimentary pharmacology \& therapeutics 2011;34:1123-1132.

18. Wilson IB, Cleary PD. Linking clinical variables with health-related quality of life: a conceptual model of patient outcomes. Jama 1995;273:59-65.

19. Ong WL, Schouwenburg MG, van Bommel AC, Stowell C, Allison KH, Benn KE, Browne JP, et al. A standard set of value-based patient-centered outcomes for breast cancer: the International Consortium for Health Outcomes Measurement (ICHOM) initiative. JAMA oncology 2017;3:677-685.

20. Zerillo JA, Schouwenburg MG, van Bommel AC, Stowell C, Lippa J, Bauer D, Berger AM, et al. An International Collaborative Standardizing a Comprehensive Patient-Centered Outcomes Measurement Set for Colorectal Cancer. Jama oncology 2017;3:686-694.

21. Mahmud I, Kelley T, Stowell C, Haripriya A, Boman A, Kossler I, Morlet N, et al. A proposed minimum standard set of outcome measures for cataract surgery. JAMA ophthalmology 2015;133:12471252.

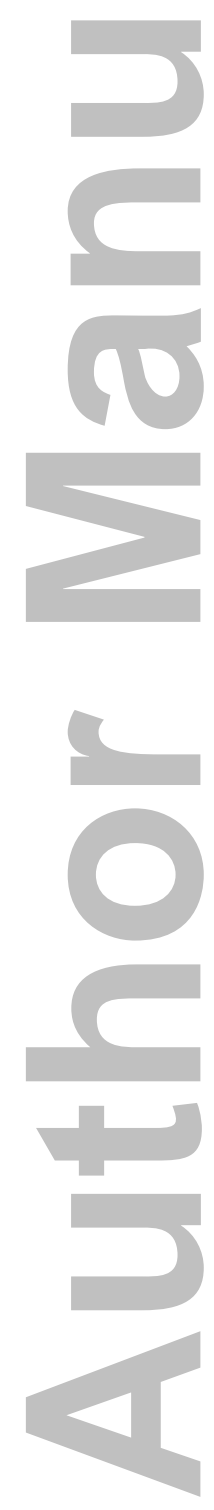




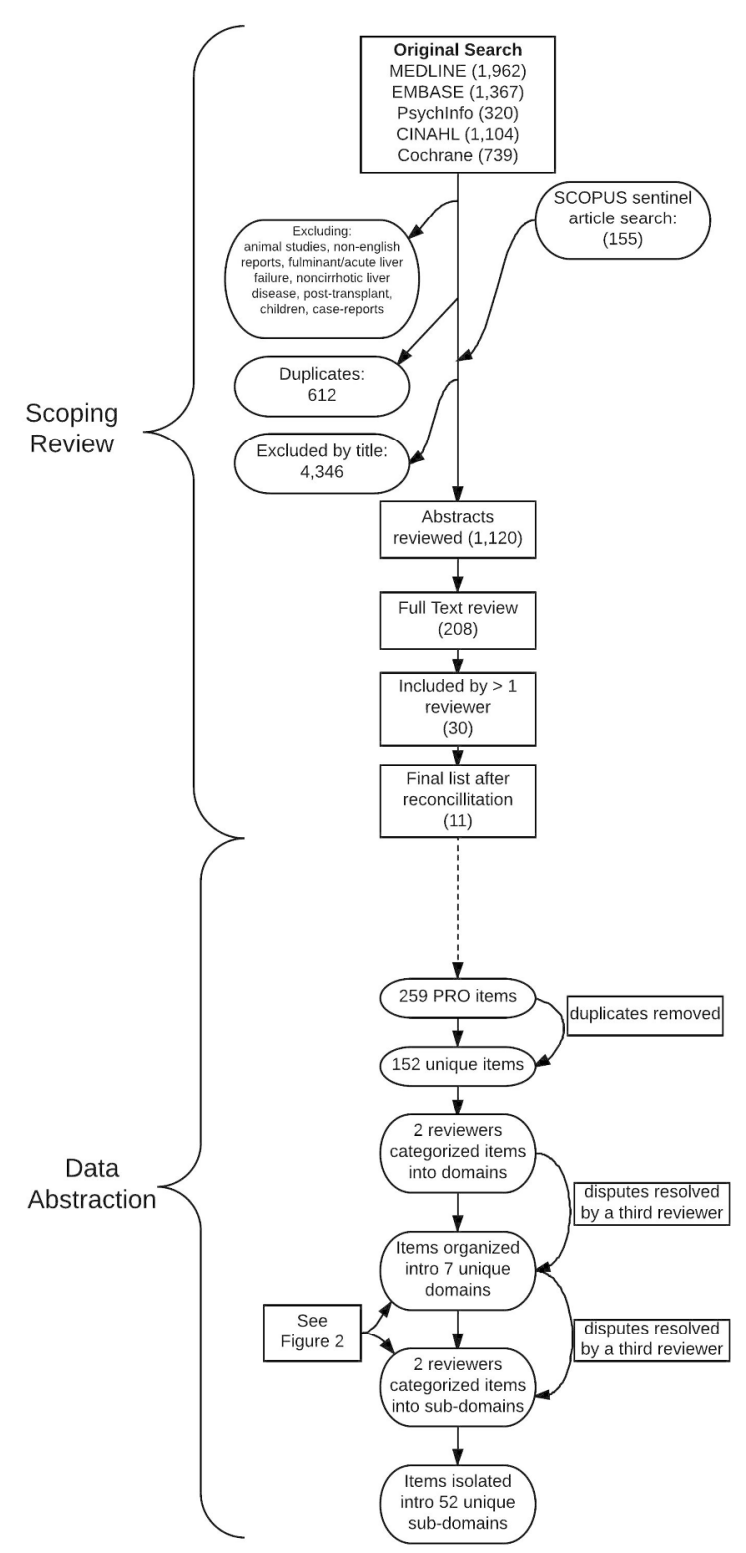

Figure 1: Flow Diagram of Study Selection

$126 \times 255 \mathrm{~mm}(300 \times 300 \mathrm{DPI})$ 


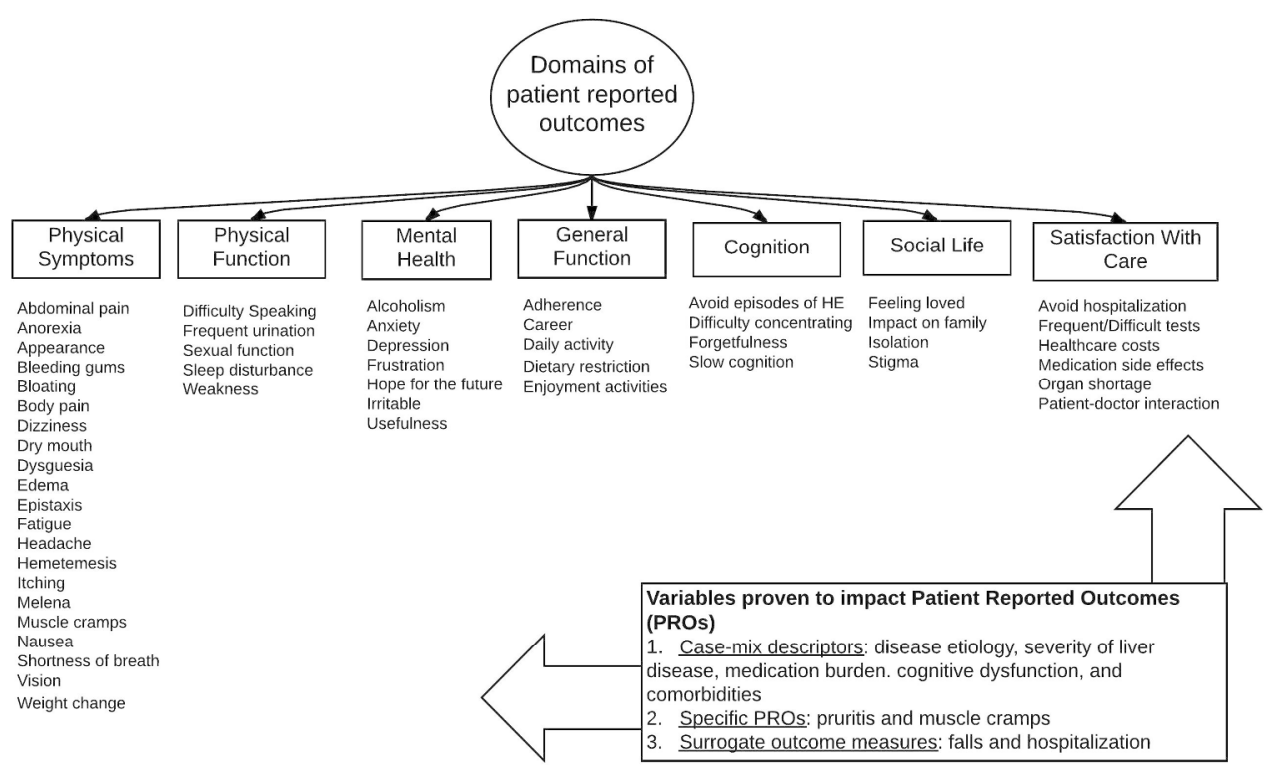

Figure 2: Domains and Sub-domains of Patient Reported Outcomes in Cirrhosis

$224 \times 137 \mathrm{~mm}(300 \times 300 \mathrm{DPI})$ 


\begin{tabular}{|c|c|c|c|}
\hline Collect PROs & $\begin{array}{l}\text { Refine and } \\
\text { Specify } \\
\text { PROs }\end{array}$ & $\begin{array}{c}\text { Determine } \\
\text { Case-Mix } \\
\text { Adjustment }\end{array}$ & $\begin{array}{c}\text { Implementation } \\
\text { and } \\
\text { Validation }\end{array}$ \\
\hline 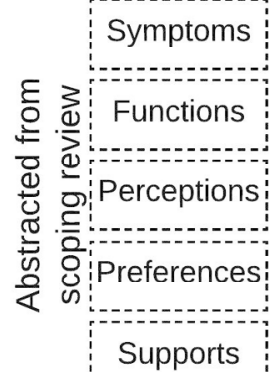 & $\begin{array}{c}\begin{array}{c}\text { Patient } \\
\text { focus } \\
\text { groups }\end{array} \\
\text { Expert } \\
\text { Delphi } \\
\text { Panel }\end{array}$ & $\begin{array}{l}\text { Etiology } \\
\text { Disease } \\
\text { severity } \\
\text { Comorbid } \\
\text { Comnesses }\end{array}$ & $\begin{array}{c}\text { Integrate PROs } \\
\text { with clinical data } \\
\text { in EHR-linked } \\
\text { registry } \\
\begin{array}{c}\text { Prospective } \\
\text { patient outcome } \\
\text { evaluation }\end{array}\end{array}$ \\
\hline
\end{tabular}

Figure 3: Overview of the Process Translating Patient Reported Outcomes (PROs) into Quality Measures!! + The goal of Practice Metrics Committee of the American Association for the Study of Liver Disease is to create a registry that tracks clinical and patient reported outcomes. To achieve this goal, the committee is developing a platform that allows for the integration of clinical data (e.g. etiology, disease severity, and comorbid illnesses) with PROs obtained during a clinical visit in the Electronic Health Record

(EHR). The work described in this paper is the crucial first step where the key PROs for patients with cirrhosis have been collected from the literature. Our next step is to refine and specify the PROs (i.e. how they will be measured) during patient focus groups and a modified Delphi-process with expert hepatologists



$164 \times 74 \mathrm{~mm}(300 \times 300 \mathrm{DPI})$ 


\begin{tabular}{|c|c|}
\hline Paper & Item \\
\hline Gralnek & I am embarrassed about how I look in public \\
\hline Gralnek & During the past 4 weeks, how often: Bleeding gums? \\
\hline Gralnek & During the past 4 weeks, how often: Bodily pain? \\
\hline Gralnek & Your ability to work around the house \\
\hline Gralnek & Doing activities involving concentration and thinking \\
\hline Gralnek & During the past 4 weeks, how often: Faintness or dizziness? \\
\hline Gralnek & During the past 4 weeks, how often: Food not tasting good? \\
\hline Gralnek & During the past 4 weeks, how often: Swelling of your feet and/or legs with fluid \\
\hline Gralnek & Doing any leisure or recreational activities inside the home \\
\hline Gralnek & During the past 4 weeks, how often: Bloody nose? \\
\hline Gralnek & How much of the time, during the past 4 weeks Have you had any trouble with your memory? \\
\hline Gralnek & During the past 4 weeks, how often: Frequent urination? \\
\hline Gralnek & How much of the time, during the past 4 weeks Were you frustrated about your liver disease? \\
\hline Gralnek & During the past 4 weeks, how often: Headaches? \\
\hline Gralnek & How much of the time, during the past 4 weeks Were you discouraged by your liver disease? \\
\hline Gralnek & Did your liver disease cause you to lose your sense of humor \\
\hline Gralnek & How much of the time, during the past 4 weeks Were you affectionate towards others? \\
\hline Gralnek & During the past weeks, how often: Nausea (upset stomach) and/or vomiting \\
\hline Gralnek & Your sex life? \\
\hline Gralnek & How much of the time during the past 4 weeks did you Get the amount of sleep you needed? \\
\hline Gralnek & During the past 4 weeks, how often: Changes in vision? \\
\hline Gralnek & During the past 4 weeks, how often: Lack of appetite? \\
\hline Gralnek & How much of the time, during the past 4 weeks Was your liver disease a worry in your life? \\
\hline Gralnek & During the past 4 weeks, how often: Soreness in your muscles? \\
\hline Gralnek & Agree? Too much of my time is spent dealing with my liver disease \\
\hline Gralnek & How much did the effects of your liver disease bother you: Any dietary restriction? \\
\hline Gralnek & Did you have difficulty reasoning and solving problems? \\
\hline Gralnek & How much of the time, during the past 4 weeks Did you become confused? \\
\hline Gralnek & How much did the effects of your liver disease bother you: Any fluid restriction? \\
\hline Gralnek & How much did the effects of your liver disease bother you: Your ability to travel? \\
\hline Gralnek & During the past 3 weeks, how often: Feeling washed out or drained \\
\hline Gralnek & How much of the time during the past 4 weeks did you Feel drowsy or sleepy during the day? \\
\hline Gralnek & Agree? I now plan less for the future than before I had liver disease \\
\hline Gralnek & Agree? I have great faith in the future \\
\hline Gralnek & Agree? I look forward to the future with hope \\
\hline Gralnek & Did you make unreasonable demands on your family and/or friends \\
\hline Gralnek & Did you act irritable toward those around you? \\
\hline Gralnek & Did you isolate yourself from people around you? \\
\hline Gralnek & How much of the time during the past 4 weeks Did you lack companionship? \\
\hline Gralnek & How much of the time during the past 4 weeks Did you feel left out? \\
\hline Gralnek & Going to social events outside your home \\
\hline Gralnek & How much of the time during the past 4 weeks Did you have no one you could turn to? \\
\hline Gralnek & How your medicines make you feel? \\
\hline Gralnek & During the past 4 weeks, how much of a problem for you was lack of sexual interest? \\
\hline Gralnek & During the past weeks, did your liver disease interfere with your sexual relationships? \\
\hline Gralnek & Have you had any sexual activity in the past weeks?* \\
\hline
\end{tabular}


Gralnek How much of a problem was Ability to satisfy sexual partner

Gralnek Overall, how satisfied were you with your sexual function during the past weeks?

Gralnek

Gralnek

During the past weeks, how often: Shortness of breath

Gralnek

Did you take naps ( minutes or longer) during the day

Gralnek

Did you react slowly to things that were said or done?

Gralnek

Agree? Some people avoid me because of my liver disease

Gralnek

Agree? My liver disease makes me stand out in public

Gralnek

Agree? Because of my liver disease I feel flawed and incomplete

Gralnek

During the past 3 weeks, how often: Black, tarry appearing bowel movements?

Gralnek

Did you feel weighed down by your liver problems?

Gralnek

During the past 4 weeks, how often: Swelling of your abdomen with fluid

Gralnek

How much of the time, during the past 4 weeks Concentrating on conversations

Gralnek

Gralnek

How much of the time, during the past 4 weeks Concentrating on a task or job

Gralnek

Did you have trouble keeping your attention on an activity for long

Gralnek

Did you Have trouble staying awake during the day?

Gralnek

Have you had trouble remembering names of people

Have you had trouble remembering where you put things

Gralnek

Gralnek

Gralnek

Gralnek

have you had trouble remembering things people tell you

have you had trouble remembering Things you read earlier in the day

Did you forget things that happened recently?

Agree? My future seems dark to me

Gralnek

Did you feel isolated from others?

Gralnek

Gralnek

Were you an outgoing person?

Were you able to find companionship when wanted it

Gralnek

During the past 4 weeks, how often: Itchy skin?

Gralnek

How much of a problem was Difficulty getting or keeping an erection

Gralnek

How much of a problem was Difficulty having orgasm

Gralnek

How much of a problem was Inadequate lubrication

Gralnek

Gralnek

Gralnek

Gralnek

Mikkelsen

Mikkelsen

How much of a problem was Difficulty having orgasm

How much of a problem was Ability to satisfy sexual partner

Did you Get enough sleep to feel rested upon waking in the morning

Agree? I avoid doing some things in public because of my liver disease

Agree? Some people are uncomfortable around me because of my liver disease

Mikkelsen

Concealment of alcohol during relapse makes them not capable of seeking help

Mikkelsen

Seek supportive acknowledgement from professionals and relatives

Desire to feel important

Mikkelsen

Mikkelsen

Do not have the strength to avoid alcohol

Think of alcohol in relation to enjoying themselves

Mikkelsen

Mikkelsen

Fear of hepatic encephalopathy

After a group therapy intervention: felt they can do more in everyday life

Mikkelsen

Mikkelsen

Mikkelsen

Mikkelsen

Mikkelsen

After a group therapy intervention: felt they can do more in everyday life

After a group therapy intervention: Daily life became more manageable

Need to experience normality

Felt better during and after exercise

Avoid hospitalization

Mikkelsen

Know that their relatives will be there for them.

Relatives are not helpful when patients are met with a lack of understanding 


\begin{tabular}{|c|c|}
\hline Mikkelsen & Desire to be a part of a community \\
\hline Mikkelsen & Seek to feel welcomed by the professionals \\
\hline Mikkelsen & Prefer the professionals to be proactive \\
\hline Mikkelsen & Feeling of security appears in interaction with professionals \\
\hline Mikkelsen & Experienced the cirrhosis clinic as a place where they could be open \\
\hline Mikkelsen & Feel a responsibility towards the professionals, \\
\hline Mikkelsen & Hand over the responsibility to the professionals to restore the diseased body \\
\hline Mikkelsen & The feeling of security gives courage to the patient to move forward \\
\hline Mikkelsen & Lack of courtesy is a threat to patients' security \\
\hline Mikkelsen & Need the professionals to set limits \\
\hline Mikkelsen & Feel not like other alcoholics, more like in a class of their own \\
\hline Mikkelsen & It is challenging for patients to be 'met with distrust \\
\hline Mikkelsen & It is challenging for patients to be met with irritation from others \\
\hline Mikkelsen & Have a failing self-esteem \\
\hline Mikkelsen & After a group therapy intervention: strengthened their muscles. \\
\hline Mikkelsen & The patient does not feel understood \\
\hline Mikkelsen & Seek involvement of others \\
\hline Mikkelsen & Felt reassured that the professionals were interested in them. \\
\hline Mikkelsen & Some patients feel that they are looked down upon \\
\hline Onishi & My stomach feels heavy when lying down. \\
\hline Onishi & My stomach is bloated, so it is difficult to move around \\
\hline Onishi & My stomach feels heavy \\
\hline Onishi & have difficulty breathing after walking for $4-3 \mathrm{~min}$ \\
\hline Onishi & cannot take deep breaths \\
\hline Onishi & My stomach is bloated and uncomfortable \\
\hline Onishi & cannot eat because my stomach is bloated \\
\hline Tsai & Speaking lower \\
\hline Tsai & Weight gain \\
\hline Tsai & Skin bruising \\
\hline Tsai & Decreased urine \\
\hline Tsai & restless or dysphoric \\
\hline Tsai & Abdominal discomfort \\
\hline Tsai & Abdominal pain \\
\hline Tsai & Worry the disease get worse \\
\hline Tsai & Worry cannot recover from disease \\
\hline Tsai & Worry symptoms will become a bigger problem \\
\hline Tsai & Anxious \\
\hline Tsai & Bleeding gums \\
\hline Tsai & Abdominal bloat \\
\hline Tsai & Ascites \\
\hline Tsai & Emotional ups and downs \\
\hline Tsai & Depressed \\
\hline Tsai & Feel down and unhappy \\
\hline Tsai & Annoyed by diet restrictions \\
\hline Tsai & Inability to eat as much as before \\
\hline Tsai & Inability to concentrate \\
\hline
\end{tabular}




\begin{tabular}{|c|c|}
\hline Tsai & Dizziness \\
\hline Tsai & Dry mouth \\
\hline Tsai & Bland tasting food \\
\hline Tsai & Leg edema \\
\hline Tsai & Nose bleeds \\
\hline Tsai & Exhaustion \\
\hline Tsai & daytime sleepy \\
\hline Tsai & Allday drowsiness \\
\hline Tsai & tiredness \\
\hline Tsai & Worry impact on family due to disease \\
\hline Tsai & itching of the skin \\
\hline Tsai & Black/tarry stools \\
\hline Tsai & Muscle cramps \\
\hline Tsai & Nausea \\
\hline Tsai & Worry about chance to obtain a donated liver for transplantation if needed \\
\hline Tsai & Shortness of breath \\
\hline Tsai & Poor sleep quality at night \\
\hline Tsai & Can't fall asleep at night \\
\hline Tsai & Acting slower \\
\hline Tsai & weakness when lifting heavy objects \\
\hline Younossi & How often during the last two weeks have you felt anxious? \\
\hline Younossi & How much of the time during the last two weeks have you felt depressed? \\
\hline Younossi & How much of the time during the last two weeks have you had a dry mouth \\
\hline Younossi & How much of the time have you been troubled by itching during the last two weeks? \\
\hline Younossi & How often during the last two weeks have you had muscle cramps? \\
\hline Younossi & Have you been concerned about the availability of a liver if you need a liver transplant? \\
\hline Younossi & Some people assume that because I have liver disease, I must have been a drinker \\
\hline Younossi & Have you been bothered by having decreased strength? \\
\hline Younossi & How much of the time during the last two weeks have you experienced abdominal pain? \\
\hline Younossi & My liver disease makes me stand out to other people \\
\hline Younossi & Have you been troubled by a feeling of abdominal bloating? \\
\hline Younossi & How much of the time during the last two weeks have you felt unhappy? \\
\hline Younossi & How much of the time during the last two weeks have you had mood swings? \\
\hline Younossi & How much of the time have you been tired or fatigued during the last two weeks? \\
\hline Younossi & How often during the last two weeks have you felt a decreased level of energy? \\
\hline Younossi & Have you been worried about never feeling any better? \\
\hline Younossi & Have you been worried about the impact your liver disease has on your family? \\
\hline Younossi & I feel lonely more often than usual because of my liver disease \\
\hline Younossi & I feel abandoned by family members because of my liver disease \\
\hline Younossi & I avoid telling other people about my liver disease \\
\hline Younossi & I feel like I am an outsider because of my liver disease \\
\hline Younossi & I avoid doing some things in public because of my liver disease \\
\hline Younossi & Some doctors or nurses don't like taking care of patients with liver disease \\
\hline Younossi & I feel like some people are concerned that my liver disease could be contagious \\
\hline Younossi & I feel like other people think I am a bad person because I have liver disease \\
\hline Younossi & People with liver disease are looked down upon by society \\
\hline
\end{tabular}


Younossi I feel I have been treated with less respect by others because of liver disease

Younossi I feel like I am partially to blame for my liver disease

Younossi I feel less competent that I did before I was diagnosed with liver disease

Younossi have you been bothered by a limitation of your diet?

Younossi have you not been able to eat as much as you would like?

Younossi have you been worried that your symptoms will develop into major problems?

Younossi have you been worried about your condition getting worse

Younossi have you been troubled by a feeling of abdominal discomfort?

Younossi have you experienced bodily pain?

Younossi have you had problems concentrating?

Younossi have you felt sleepy during the day?

Younossi How often during the last two weeks have you felt drowsy?

Younossi How often during the last two weeks have you been irritable?

Younossi Has shortness of breath been a problem for you in your daily activities?

Younossi have you had difficulty sleeping at night?

Younossi Have you been unable to fall asleep at night?

Younossi Other people think I am partially to blame for my liver disease

Younossi Because of my liver disease, I feel flawed and incomplete

Younossi Some people avoid me because of my liver disease

Younossi Because of my liver disease, I sometimes feel useless

Younossi have you had trouble lifting or carrying heavy objects?

Zhang I was annoyed at abdominal pain and indigestion

Zhang I can follow the doctor's advice to give up bad living habits

Zhang I was worried about that the disease would affect my work and promotion

Zhang I continued to work

Zhang I can do shopping as usual

Zhang My relatives cared about my disease

Zhang I was satisfied with the healthcare costs

Zhang I had hemetemesis

Zhang The disease affected my interpersonal relationships

Zhang I was worried about side effects of drugs

Zhang I was losing weight

Zhang I can take medicine following doctors advice

Zhang I was tired of taking medicine often

Zhang I felt anxious about my disease outcome

Zhang I was easy to relax being with others

Zhang I felt upset or fear easily

Zhang I felt angry easier than usual

Zhang My face looked dark and dull

Zhang I was pessimistic and there was nothing to make me happy

Zhang I gave up my hobbies

Zhang I lost interests in what interested me before

Zhang I can do simple outdoor activity (walking)

Zhang My family comforted me

Zhang I was lack of initiative in social life 


$\begin{array}{ll}\text { Zhang } & \text { I had melena } \\ \text { Zhang } & \text { I felt annoyed about drawing blood and taking ultrasonic examination } \\ \text { Zhang } & \text { I was satisfied with current treatments } \\ \text { Zhang } & \text { I can go to visit doctors regularly } \\ \text { Zhang } & \text { I felt uncomfortable about my friends' strange eyes or attitude after I was ill } \\ \text { Zhang } & \text { I avoided social occasions or activities because of disease (e.g. parties) } \\ \text { Zhang } & \text { I felt loss of appetite } \\ \text { Zhang } & \text { I felt fatigue } \\ \text { Zhang } & \text { I was slow in reacting } \\ \text { Zhang } & \text { had pain in right upper quadrant } \\ \text { Zhang } & \text { I was worried my liver disease would cause more serious disease (e.g. cancer) } \\ \text { Zhang } & \text { I felt anxious easier than usual } \\ \text { Zhang } & \text { I felt abdominal distension } \\ \text { Zhang } & \text { I felt in a blue mood } \\ \text { Zhang } & \text { I felt like crying } \\ \text { Zhang } & \text { I had abnormal taste } \\ \text { Zhang } & \text { I had edema in my legs } \\ \text { Zhang } & \text { I felt sleepy in daytime } \\ \text { Zhang } & \text { I felt forgetful } \\ \text { Zhang } & \text { I didn't have any hope about my future } \\ \text { Zhang } & \text { I felt vague about my future } \\ \text { Zhang } & \text { I was worried my liver disease would affect my family } \\ \text { Zhang } & \text { I felt itchy in skin } \\ \text { Zhang } & \text { I vomited for nauseated } \\ \text { Zhang } & \text { I was satisfied with the medical services } \\ \text { Zhang } & \text { I had poor sleep at night } \\ \text { Zhang } & \text { I felt someone avoided me deliberately } \\ \text { Zhang } & \text { I felt unuseful about myself } \\ \text { Zhang } & \text { I can do simple housework } \\ \text { Zhang } & \text { I felt annoyed about drawing blood and taking ultrasonic examination } \\ & \text { I }\end{array}$

Note: In many instances, the item wording was reduced for this table by removing preambles in order to fit the operative part of the item in this supplement for easy review. Examples include "How often in the last 2 weeks have you..." or "How has your liver disease affected your..."

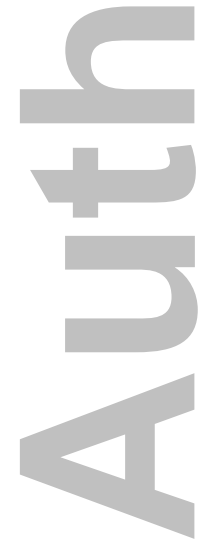




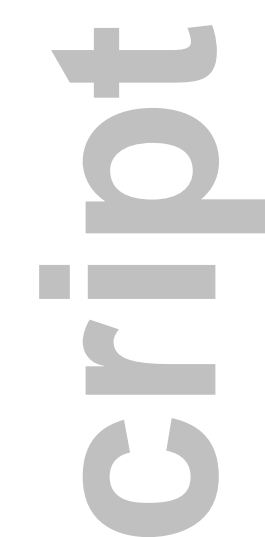

Technical Supplement: Search terms and search strings by database

\section{Table of Contents}

1. CINAHL - page 2-17

2. EMBASE - page $18-19$

3. PsychINFO - page 20-43

4. Cochrane - page $44-45$

5. Pubmed - page 46
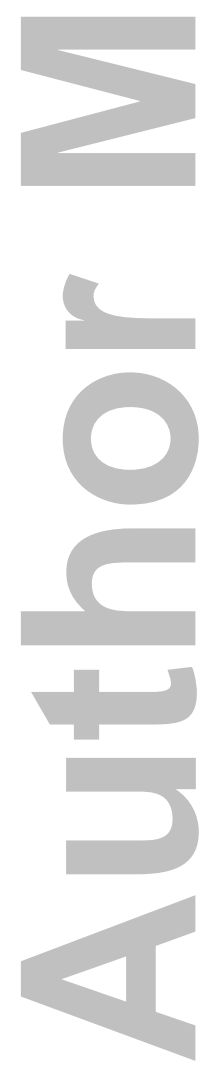


\begin{tabular}{|c|c|c|c|c|}
\hline \multirow{2}{*}{$\begin{array}{l}\# \\
\text { S122 }\end{array}$} & \multirow[b]{2}{*}{ Query } & \multirow[b]{2}{*}{ Limiters/Expanders } & \multicolumn{2}{|l|}{ Monday, May 01, 2017 9:48:37 AM } \\
\hline & & & Last Run Via & Results \\
\hline S122 & $\begin{array}{l}\text { ( (S88 OR S89 OR S90 } \\
\text { OR S91 OR S92 OR S93 } \\
\text { OR S94 OR S95 OR S96 } \\
\text { OR S97 OR S98 OR S99 } \\
\text { OR S100 OR S101 OR } \\
\text { S102 OR S103 OR S104 } \\
\text { OR S105 OR S106 OR } \\
\text { S107 OR S108 OR S109 } \\
\text { OR S110 OR S111 OR } \\
\text { S112 OR S113 OR S114 } \\
\text { OR S115 OR S116 OR } \\
\text { S117 OR S118 OR S119) } \\
\text { AND (S87 AND S120) ) } \\
\text { AND LA english }\end{array}$ & $\begin{array}{l}\text { Search modes - } \\
\text { Boolean/Phrase }\end{array}$ & $\begin{array}{l}\text { Interface - EBSCOhost } \\
\text { Research Databases } \\
\text { Search Screen - Advanced } \\
\text { Search } \\
\text { Database - CINAHL Complete }\end{array}$ & 1,104 \\
\hline S121 & $\begin{array}{l}\text { (S88 OR S89 OR S90 } \\
\text { OR S91 OR S92 OR S93 } \\
\text { OR S94 OR S95 OR S96 } \\
\text { OR S97 OR S98 OR S99 } \\
\text { OR S100 OR S101 OR } \\
\text { S102 OR S103 OR S104 } \\
\text { OR S105 OR S106 OR } \\
\text { S107 OR S108 OR S109 } \\
\text { OR S110 OR S111 OR } \\
\text { S112 OR S113 OR S114 } \\
\text { OR S115 OR S116 OR } \\
\text { S117 OR S118 OR S119) } \\
\text { AND (S87 AND S120) }\end{array}$ & $\begin{array}{l}\text { Search modes - } \\
\text { Boolean/Phrase }\end{array}$ & $\begin{array}{l}\text { Interface - EBSCOhost } \\
\text { Research Databases } \\
\text { Search Screen - Advanced } \\
\text { Search } \\
\text { Database - CINAHL Complete }\end{array}$ & Display \\
\hline S120 & $\begin{array}{l}\text { S88 OR S89 OR S90 OR } \\
\text { S91 OR S92 OR S93 OR } \\
\text { S94 OR S95 OR S96 OR } \\
\text { S97 OR S98 OR S99 OR } \\
\text { S100 OR S101 OR S102 } \\
\text { OR S103 OR S104 OR } \\
\text { S105 OR S106 OR S107 } \\
\text { OR S108 OR S109 OR } \\
\text { S110 OR S111 OR S112 } \\
\text { OR S113 OR S114 OR } \\
\text { S115 OR S116 OR S117 }\end{array}$ & $\begin{array}{l}\text { Search modes - } \\
\text { Boolean/Phrase }\end{array}$ & $\begin{array}{l}\text { Interface - EBSCOhost } \\
\text { Research Databases } \\
\text { Search Screen - Advanced } \\
\text { Search } \\
\text { Database - CINAHL Complete }\end{array}$ & Display \\
\hline & & $\mathrm{He}$ & & \\
\hline
\end{tabular}

This article is protected by copyright. All rights reserved.

Interface - EBSCOhost
Search Screen - Advanced

Database - CINAHL Complete

Interface - EBSCOhost

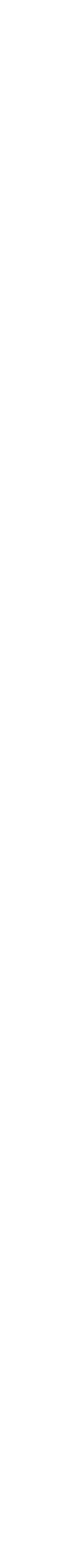

Doolean/Phrase

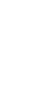


OR S118 OR S119

\section{S119 (patient $n 10$ reported)
AND (satisfaction or outcome* or measure* or "quality of life")}
S118 "'"quality of life"' OR (MH "Quality of Life+")
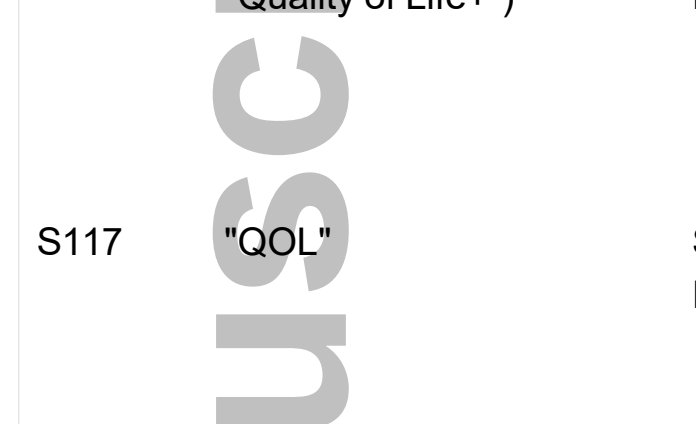

S116 "'"health related quality of
life"'"
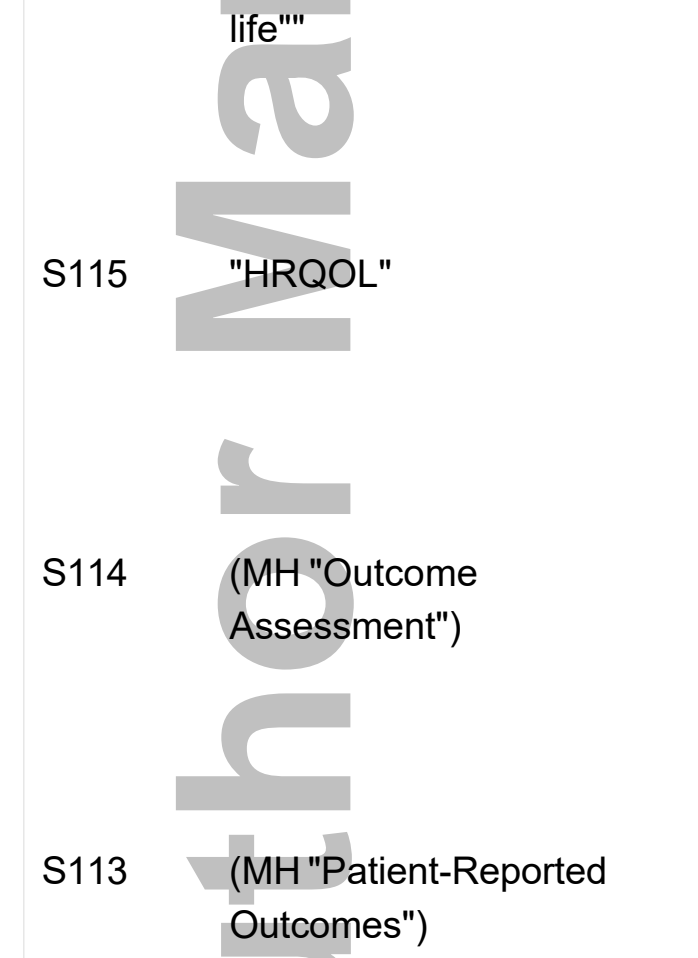

S112
Search modes -
Boolean/Phrase

Search modes -

Boolean/Phrase

Search modes -

Boolean/Phrase

\author{
Search modes - \\ Boolean/Phrase
}

Search modes -

Boolean/Phrase

Search modes Boolean/Phrase

Search modes -

Boolean/Phrase

Search modes -

Boolean/Phrase
Interface - EBSCOhost

Research Databases

Search Screen - Advanced

Search

Database - CINAHL Complete

Interface - EBSCOhost

Research Databases

Search Screen - Advanced

Search

Database - CINAHL Complete

Interface - EBSCOhost

Research Databases

Search Screen - Advanced

Search

Database - CINAHL Complete

Interface - EBSCOhost

Research Databases

Search Screen - Advanced

Search

Database - CINAHL Complete

Interface - EBSCOhost

Research Databases

Search Screen - Advanced

Search

Database - CINAHL Complete

Interface - EBSCOhost

Research Databases

Search Screen - Advanced

Search

Database - CINAHL Complete

Interface - EBSCOhost

Research Databases

Search Screen - Advanced

Search

Database - CINAHL Complete

Interface - EBSCOhost

Display

Display

Display

Display

Display

Display

Display

Research Databases

Search Screen - Advanced

Search

Database - CINAHL Complete 


\begin{tabular}{|c|c|c|c|c|}
\hline S111 & NHP & $\begin{array}{l}\text { Search modes - } \\
\text { Boolean/Phrase }\end{array}$ & $\begin{array}{l}\text { Interface - EBSCOhost } \\
\text { Research Databases } \\
\text { Search Screen - Advanced } \\
\text { Search } \\
\text { Database - CINAHL Complete }\end{array}$ & Display \\
\hline S110 & $\begin{array}{l}\text { "'nottingham health } \\
\text { profile"" }\end{array}$ & $\begin{array}{l}\text { Search modes - } \\
\text { Boolean/Phrase }\end{array}$ & $\begin{array}{l}\text { Interface - EBSCOhost } \\
\text { Research Databases } \\
\text { Search Screen - Advanced } \\
\text { Search } \\
\text { Database - CINAHL Complete }\end{array}$ & Display \\
\hline S109 & $\begin{array}{l}\text { "'multi-dimensional } \\
\text { fatigue inventory"'" }\end{array}$ & $\begin{array}{l}\text { Search modes - } \\
\text { Boolean/Phrase }\end{array}$ & $\begin{array}{l}\text { Interface - EBSCOhost } \\
\text { Research Databases } \\
\text { Search Screen - Advanced } \\
\text { Search } \\
\text { Database - CINAHL Complete }\end{array}$ & Display \\
\hline S108 & "c & $\begin{array}{l}\text { Search modes - } \\
\text { Boolean/Phrase }\end{array}$ & $\begin{array}{l}\text { Interface - EBSCOhost } \\
\text { Research Databases } \\
\text { Search Screen - Advanced } \\
\text { Search } \\
\text { Database - CINAHL Complete }\end{array}$ & Display \\
\hline S107 & "fac & $\begin{array}{l}\text { Search modes - } \\
\text { Boolean/Phrase }\end{array}$ & $\begin{array}{l}\text { Interface - EBSCOhost } \\
\text { Research Databases } \\
\text { Search Screen - Advanced } \\
\text { Search } \\
\text { Database - CINAHL Complete }\end{array}$ & Display \\
\hline S106 & "mfsi-sf" & $\begin{array}{l}\text { Search modes - } \\
\text { Boolean/Phrase }\end{array}$ & $\begin{array}{l}\text { Interface - EBSCOhost } \\
\text { Research Databases } \\
\text { Search Screen - Basic Search } \\
\text { Database - CINAHL Complete }\end{array}$ & Display \\
\hline S105 & $\begin{array}{l}\text { "'sickness impact } \\
\text { profile"" }\end{array}$ & $\begin{array}{l}\text { Search modes - } \\
\text { Boolean/Phrase }\end{array}$ & $\begin{array}{l}\text { Interface - EBSCOhost } \\
\text { Research Databases } \\
\text { Search Screen - Basic Search } \\
\text { Database - CINAHL Complete }\end{array}$ & Display \\
\hline S104 & $\begin{array}{l}\text { (MH "Sickness Impact } \\
\text { Profile") }\end{array}$ & $\begin{array}{l}\text { Search modes - } \\
\text { Boolean/Phrase }\end{array}$ & $\begin{array}{l}\text { Interface - EBSCOhost } \\
\text { Research Databases } \\
\text { Search Screen - Basic Search } \\
\text { Database - CINAHL Complete }\end{array}$ & Display \\
\hline S103 & $\begin{array}{l}\text { "'liver disease symptom } \\
\text { index"'" }\end{array}$ & $\begin{array}{l}\text { Search modes - } \\
\text { Boolean/Phrase }\end{array}$ & $\begin{array}{l}\text { Interface - EBSCOhost } \\
\text { Research Databases } \\
\text { Search Screen - Basic Search } \\
\text { Database - CINAHL Complete }\end{array}$ & Display \\
\hline
\end{tabular}

This article is protected by copyright. All rights reserved. 


\begin{tabular}{|c|c|c|c|c|}
\hline S102 & "LDSI" & $\begin{array}{l}\text { Search modes - } \\
\text { Boolean/Phrase }\end{array}$ & $\begin{array}{l}\text { Interface - EBSCOhost } \\
\text { Research Databases } \\
\text { Search Screen - Basic Search } \\
\text { Database - CINAHL Complete }\end{array}$ & Display \\
\hline S101 & sf36 OR sf-36 & $\begin{array}{l}\text { Search modes - } \\
\text { Boolean/Phrase }\end{array}$ & $\begin{array}{l}\text { Interface - EBSCOhost } \\
\text { Research Databases } \\
\text { Search Screen - Basic Search } \\
\text { Database - CINAHL Complete }\end{array}$ & Display \\
\hline S100 & "'short form 36"" & $\begin{array}{l}\text { Search modes - } \\
\text { Boolean/Phrase }\end{array}$ & $\begin{array}{l}\text { Interface - EBSCOhost } \\
\text { Research Databases } \\
\text { Search Screen - Basic Search } \\
\text { Database - CINAHL Complete }\end{array}$ & Display \\
\hline S99 & $\begin{array}{l}\text { (MH "Short Form-36 } \\
\text { Health Survey (SF-36)") }\end{array}$ & $\begin{array}{l}\text { Search modes - } \\
\text { Boolean/Phrase }\end{array}$ & $\begin{array}{l}\text { Interface - EBSCOhost } \\
\text { Research Databases } \\
\text { Search Screen - Basic Search } \\
\text { Database - CINAHL Complete }\end{array}$ & Display \\
\hline S98 & "short form 8" & $\begin{array}{l}\text { Search modes - } \\
\text { Boolean/Phrase }\end{array}$ & $\begin{array}{l}\text { Interface - EBSCOhost } \\
\text { Research Databases } \\
\text { Search Screen - Basic Search } \\
\text { Database - CINAHL Complete }\end{array}$ & Display \\
\hline S97 & sf 16 or sf-16 & $\begin{array}{l}\text { Search modes - } \\
\text { Boolean/Phrase }\end{array}$ & $\begin{array}{l}\text { Interface - EBSCOhost } \\
\text { Research Databases } \\
\text { Search Screen - Basic Search } \\
\text { Database - CINAHL Complete }\end{array}$ & Display \\
\hline S96 & "'short form 16"' & $\begin{array}{l}\text { Search modes - } \\
\text { Boolean/Phrase }\end{array}$ & $\begin{array}{l}\text { Interface - EBSCOhost } \\
\text { Research Databases } \\
\text { Search Screen - Basic Search } \\
\text { Database - CINAHL Complete }\end{array}$ & Display \\
\hline S95 & & $\begin{array}{l}\text { Search modes - } \\
\text { Boolean/Phrase }\end{array}$ & $\begin{array}{l}\text { Interface - EBSCOhost } \\
\text { Research Databases } \\
\text { Search Screen - Basic Search } \\
\text { Database - CINAHL Complete }\end{array}$ & Display \\
\hline S94 & "'short form 8"' & $\begin{array}{l}\text { Search modes - } \\
\text { Boolean/Phrase }\end{array}$ & $\begin{array}{l}\text { Interface - EBSCOhost } \\
\text { Research Databases } \\
\text { Search Screen - Basic Search } \\
\text { Database - CINAHL Complete }\end{array}$ & Display \\
\hline S93 & WPAI & $\begin{array}{l}\text { Search modes - } \\
\text { Boolean/Phrase }\end{array}$ & $\begin{array}{l}\text { Interface - EBSCOhost } \\
\text { Research Databases } \\
\text { Search Screen - Basic Search } \\
\text { Database - CINAHL Complete }\end{array}$ & Display \\
\hline
\end{tabular}




\begin{tabular}{|c|c|c|c|c|}
\hline S92 & $\begin{array}{l}\text { "'work productivity and } \\
\text { impairment"' }\end{array}$ & $\begin{array}{l}\text { Search modes - } \\
\text { Boolean/Phrase }\end{array}$ & $\begin{array}{l}\text { Interface - EBSCOhost } \\
\text { Research Databases } \\
\text { Search Screen - Basic Search } \\
\text { Database - CINAHL Complete }\end{array}$ & Display \\
\hline S91 & $\begin{array}{l}\text { "'liver disease quality of } \\
\text { life"'" }\end{array}$ & $\begin{array}{l}\text { Search modes - } \\
\text { Boolean/Phrase }\end{array}$ & $\begin{array}{l}\text { Interface - EBSCOhost } \\
\text { Research Databases } \\
\text { Search Screen - Basic Search } \\
\text { Database - CINAHL Complete }\end{array}$ & Display \\
\hline S90 & "LDQOL" & $\begin{array}{l}\text { Search modes - } \\
\text { Boolean/Phrase }\end{array}$ & $\begin{array}{l}\text { Interface - EBSCOhost } \\
\text { Research Databases } \\
\text { Search Screen - Basic Search } \\
\text { Database - CINAHL Complete }\end{array}$ & Display \\
\hline S89 & "CLDQ" & $\begin{array}{l}\text { Search modes - } \\
\text { Boolean/Phrase }\end{array}$ & $\begin{array}{l}\text { Interface - EBSCOhost } \\
\text { Research Databases } \\
\text { Search Screen - Basic Search } \\
\text { Database - CINAHL Complete }\end{array}$ & Display \\
\hline S88 & $\begin{array}{l}\text { "chronic liver disease } \\
\text { questionnaire" }\end{array}$ & $\begin{array}{l}\text { Search modes - } \\
\text { Boolean/Phrase }\end{array}$ & $\begin{array}{l}\text { Interface - EBSCOhost } \\
\text { Research Databases } \\
\text { Search Screen - Basic Search } \\
\text { Database - CINAHL Complete }\end{array}$ & Display \\
\hline S87 & $\begin{array}{l}\text { (S62 OR S63 OR S64 } \\
\text { OR S65 OR S66 OR S67 } \\
\text { OR S68 OR S69 OR S70 } \\
\text { OR S71 OR S72 OR S73 } \\
\text { OR S74 OR S75 OR S76 } \\
\text { OR S77 OR S78 OR S79 } \\
\text { OR S80 OR S81 OR S82 } \\
\text { OR S83 OR S84 OR S85 } \\
\text { OR S86) }\end{array}$ & $\begin{array}{l}\text { Search modes - } \\
\text { Boolean/Phrase }\end{array}$ & $\begin{array}{l}\text { Interface - EBSCOhost } \\
\text { Research Databases } \\
\text { Search Screen - Advanced } \\
\text { Search } \\
\text { Database - CINAHL Complete }\end{array}$ & Display \\
\hline S86 & "liver cirrhosis" & $\begin{array}{l}\text { Search modes - } \\
\text { Boolean/Phrase }\end{array}$ & $\begin{array}{l}\text { Interface - EBSCOhost } \\
\text { Research Databases } \\
\text { Search Screen - Advanced } \\
\text { Search } \\
\text { Database - CINAHL Complete }\end{array}$ & Display \\
\hline S85 & (MH "Liver Cirrhosis+") & $\begin{array}{l}\text { Search modes - } \\
\text { Boolean/Phrase }\end{array}$ & $\begin{array}{l}\text { Interface - EBSCOhost } \\
\text { Research Databases } \\
\text { Search Screen - Advanced } \\
\text { Search } \\
\text { Database - CINAHL Complete }\end{array}$ & Display \\
\hline S84 & "hepatitis c" & $\begin{array}{l}\text { Search modes - } \\
\text { Boolean/Phrase }\end{array}$ & $\begin{array}{l}\text { Interface - EBSCOhost } \\
\text { Research Databases }\end{array}$ & Display \\
\hline
\end{tabular}


Search Screen - Advanced

Search

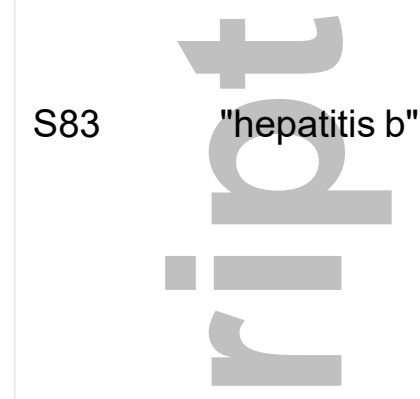

Database - CINAHL Complete

Search modes -

Interface - EBSCOhost

Display

Boolean/Phrase

S82 (MH "Hepatitis B+")

Search modes -

Boolean/Phrase

Research Databases

Search Screen - Advanced

Search

Database - CINAHL Complete

Interface - EBSCOhost

Display

Research Databases

Search Screen - Advanced

Search

Database - CINAHL Complete

S81 (MH "Hepatitis C+")

Search modes -

Interface - EBSCOhost

Display

Boolean/Phrase

Research Databases

Search Screen - Advanced

Search

Database - CINAHL Complete

S80 (MH "Liver Diseases,

Search modes -

Interface - EBSCOhost

Display Alcoholic+")

Boolean/Phrase

Research Databases

Search Screen - Advanced

Search

Database - CINAHL Complete

Search modes -

Interface - EBSCOhost

Display

Boolean/Phrase

Research Databases

alcoholic

Search Screen - Advanced

Search

Database - CINAHL Complete

$\begin{array}{cl}\text { S78 fatty liver" AND ( } & \text { Search modes - } \\ \text { non-alcoholic or } & \text { Boolean/Phrase }\end{array}$

Interface - EBSCOhost

Display

Research Databases

nonalcoholic )

Search Screen - Advanced

Search

Database - CINAHL Complete

S77 (MH "Nonalcoholic Fatty Liver Disease")

Search modes -

Interface - EBSCOhost

Display

Boolean/Phrase

Research Databases

Search Screen - Advanced

Search

Database - CINAHL Complete

Search modes -

Interface - EBSCOhost

Display

Boolean/Phrase

Research Databases

Search Screen - Advanced

Hepatology

This article is protected by copyright. All rights reserved. 


\begin{tabular}{|c|c|c|c|c|}
\hline & & & $\begin{array}{l}\text { Search } \\
\text { Database - CINAHL Complete }\end{array}$ & \\
\hline S75 & "chronic hepatitis" & $\begin{array}{l}\text { Search modes - } \\
\text { Boolean/Phrase }\end{array}$ & $\begin{array}{l}\text { Interface - EBSCOhost } \\
\text { Research Databases } \\
\text { Search Screen - Advanced } \\
\text { Search } \\
\text { Database - CINAHL Complete }\end{array}$ & Display \\
\hline S74 & $\begin{array}{l}\text { (MH "Hepatitis, Viral, } \\
\text { Human") }\end{array}$ & $\begin{array}{l}\text { Search modes - } \\
\text { Boolean/Phrase }\end{array}$ & $\begin{array}{l}\text { Interface - EBSCOhost } \\
\text { Research Databases } \\
\text { Search Screen - Advanced } \\
\text { Search } \\
\text { Database - CINAHL Complete }\end{array}$ & Display \\
\hline S73 & (MH "Hepatitis, Chronic") & $\begin{array}{l}\text { Search modes - } \\
\text { Boolean/Phrase }\end{array}$ & $\begin{array}{l}\text { Interface - EBSCOhost } \\
\text { Research Databases } \\
\text { Search Screen - Advanced } \\
\text { Search } \\
\text { Database - CINAHL Complete }\end{array}$ & Display \\
\hline S72 & $\begin{array}{l}\text { (MH "Hepatorenal } \\
\text { Syndrome") OR } \\
\text { "Hepatorenal Syndrome" }\end{array}$ & $\begin{array}{l}\text { Search modes - } \\
\text { Boolean/Phrase }\end{array}$ & $\begin{array}{l}\text { Interface - EBSCOhost } \\
\text { Research Databases } \\
\text { Search Screen - Advanced } \\
\text { Search } \\
\text { Database - CINAHL Complete }\end{array}$ & Display \\
\hline S71 & $\begin{array}{l}\text { (MH "Hepatopulmonary } \\
\text { Syndrome") OR } \\
\text { "Hepatopulmonary } \\
\text { Syndrome" }\end{array}$ & $\begin{array}{l}\text { Search modes - } \\
\text { Boolean/Phrase }\end{array}$ & $\begin{array}{l}\text { Interface - EBSCOhost } \\
\text { Research Databases } \\
\text { Search Screen - Advanced } \\
\text { Search } \\
\text { Database - CINAHL Complete }\end{array}$ & Display \\
\hline S70 & $\begin{array}{l}\text { (MH } \\
\text { "Cholangiocarcinoma") } \\
\text { OR } \\
\text { "Cholangiocarcinoma" }\end{array}$ & $\begin{array}{l}\text { Search modes - } \\
\text { Boolean/Phrase }\end{array}$ & $\begin{array}{l}\text { Interface - EBSCOhost } \\
\text { Research Databases } \\
\text { Search Screen - Advanced } \\
\text { Search } \\
\text { Database - CINAHL Complete }\end{array}$ & Display \\
\hline S69 & cirrhosis & $\begin{array}{l}\text { Search modes - } \\
\text { Boolean/Phrase }\end{array}$ & $\begin{array}{l}\text { Interface - EBSCOhost } \\
\text { Research Databases } \\
\text { Search Screen - Advanced } \\
\text { Search } \\
\text { Database - CINAHL Complete }\end{array}$ & Display \\
\hline S68 & HBV & $\begin{array}{l}\text { Search modes - } \\
\text { Boolean/Phrase }\end{array}$ & $\begin{array}{l}\text { Interface - EBSCOhost } \\
\text { Research Databases } \\
\text { Search Screen - Advanced } \\
\text { Search }\end{array}$ & Display \\
\hline
\end{tabular}

This article is protected by copyright. All rights reserved. 
S67

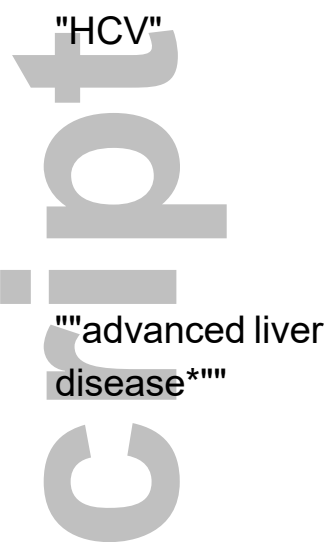

S65

S66

"chronic liver disease*"

S64

hcc

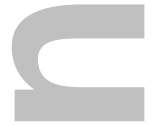

S63

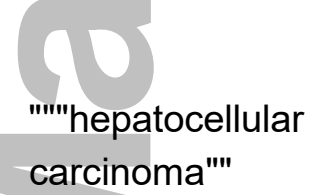

carcinoma"'"

S62

(MH "Carcinoma, Hepatocellular") OR

"Carcinoma, Hepatocellular"

S61

( ( 227 OR S28 OR S29 OR S30 OR S31 OR S32

OR S33 OR S34 OR S35

OR S36 OR S37 OR S38 OR S39 OR S40 OR S41 OR S42 OR S43 OR S44 OR S45 OR S46 OR S47 OR S48 OR S49 OR S50 OR S51 OR S52 OR S53 OR S54 OR S55 OR S56 OR S57 OR S58) AND (S26 AND S59) ) AND LA english
Database - CINAHL Complete
Search modes -

Boolean/Phrase

Search modes -

Boolean/Phrase

Search modes -

Boolean/Phrase

Search modes -

Boolean/Phrase

Search modes -

Boolean/Phrase
Interface - EBSCOhost

Research Databases

Search Screen - Advanced

Search

Database - CINAHL Complete

Interface - EBSCOhost

Research Databases

Search Screen - Basic Search

Database - CINAHL Complete

Interface - EBSCOhost

Display

Research Databases

Search Screen - Basic Search

Database - CINAHL Complete

Interface - EBSCOhost

Display

Research Databases

Search Screen - Advanced

Search

Database - CINAHL Complete

Interface - EBSCOhost

Display

Research Databases

Search Screen - Advanced

Search

Database - CINAHL Complete

Interface - EBSCOhost

Display

Research Databases

Search Screen - Advanced

Search

Database - CINAHL Complete

Interface - EBSCOhost

1,104

Research Databases

Search Screen - Advanced

Search

Database - CINAHL Complete 

S60
(S27 OR S28 OR S29
OR S30 OR S31 OR S32
OR S33 OR S34 OR S35
OR S36 OR S37 OR S38
OR S39 OR S40 OR S41
OR S42 OR S43 OR S44
OR S45 OR S46 OR S47
OR S48 OR S49 OR S50
OR S51 OR S52 OR S53
OR S54 OR S55 OR S56
OR S57 OR S58) AND
(S26 AND S59)

S59 S27 OR S28 OR S29 OR S30 OR S31 OR S32 OR S33 OR S34 OR S35 OR S36 OR S37 OR S38 OR S39 OR S40 OR S41 OR S42 OR S43 OR S44 OR S45 OR S46 OR S47 OR S48 OR S49 OR S50 OR S51 OR S52 OR S53 OR S54 OR S55 OR S56 OR S57 OR S58

S58

(patient $\mathrm{n} 10$ reported)

AND (satisfaction or outcome* or measure* or "quality of life")



Search modes -

Boolean/Phrase

Search modes -

Boolean/Phrase

Search modes -

Boolean/Phrase

Search modes -

Boolean/Phrase

Search modes -

Boolean/Phrase

Search modes -

Boolean/Phrase
Interface - EBSCOhost

Research Databases

Search Screen - Advanced

Search

Database - CINAHL Complete
1,134

176,244

Interface - EBSCOhost

Research Databases

Search Screen - Advanced

Search

Database - CINAHL Complete

26,931

Interface - EBSCOhost

Research Databases

Search Screen - Advanced

Search

Database - CINAHL Complete

Interface - EBSCOhost

Display

Research Databases

Search Screen - Advanced

Search

Database - CINAHL Complete

Interface - EBSCOhost

Display

Research Databases

Search Screen - Advanced

Search

Database - CINAHL Complete

Interface - EBSCOhost

Display

Research Databases

Search Screen - Advanced

Search

Database - CINAHL Complete 


\begin{tabular}{|c|c|c|c|c|}
\hline S54 & "HRQOL" & $\begin{array}{l}\text { Search modes - } \\
\text { Boolean/Phrase }\end{array}$ & $\begin{array}{l}\text { Interface - EBSCOhost } \\
\text { Research Databases } \\
\text { Search Screen - Advanced } \\
\text { Search } \\
\text { Database - CINAHL Complete }\end{array}$ & Display \\
\hline S53 & $\begin{array}{l}\text { (MH "Outcome } \\
\text { Assessment") }\end{array}$ & $\begin{array}{l}\text { Search modes - } \\
\text { Boolean/Phrase }\end{array}$ & $\begin{array}{l}\text { Interface - EBSCOhost } \\
\text { Research Databases } \\
\text { Search Screen - Advanced } \\
\text { Search } \\
\text { Database - CINAHL Complete }\end{array}$ & Display \\
\hline S52 & $\begin{array}{l}\text { (MH "Patient-Reported } \\
\text { Outcomes") }\end{array}$ & $\begin{array}{l}\text { Search modes - } \\
\text { Boolean/Phrase }\end{array}$ & $\begin{array}{l}\text { Interface - EBSCOhost } \\
\text { Research Databases } \\
\text { Search Screen - Advanced } \\
\text { Search } \\
\text { Database - CINAHL Complete }\end{array}$ & Display \\
\hline S51 & "EuroQOL-5D" & $\begin{array}{l}\text { Search modes - } \\
\text { Boolean/Phrase }\end{array}$ & $\begin{array}{l}\text { Interface - EBSCOhost } \\
\text { Research Databases } \\
\text { Search Screen - Advanced } \\
\text { Search } \\
\text { Database - CINAHL Complete }\end{array}$ & Display \\
\hline S50 & $\mathrm{NHP}$ & $\begin{array}{l}\text { Search modes - } \\
\text { Boolean/Phrase }\end{array}$ & $\begin{array}{l}\text { Interface - EBSCOhost } \\
\text { Research Databases } \\
\text { Search Screen - Advanced } \\
\text { Search } \\
\text { Database - CINAHL Complete }\end{array}$ & Display \\
\hline S49 & $\begin{array}{l}\text { "'"nottingham health } \\
\text { profile"'" }\end{array}$ & $\begin{array}{l}\text { Search modes - } \\
\text { Boolean/Phrase }\end{array}$ & $\begin{array}{l}\text { Interface - EBSCOhost } \\
\text { Research Databases } \\
\text { Search Screen - Advanced } \\
\text { Search } \\
\text { Database - CINAHL Complete }\end{array}$ & Display \\
\hline S48 & "'"multi-dimensional & $\begin{array}{l}\text { Search modes - } \\
\text { Boolean/Phrase }\end{array}$ & $\begin{array}{l}\text { Interface - EBSCOhost } \\
\text { Research Databases } \\
\text { Search Screen - Advanced } \\
\text { Search } \\
\text { Database - CINAHL Complete }\end{array}$ & Display \\
\hline S47 & "sf-6d" & $\begin{array}{l}\text { Search modes - } \\
\text { Boolean/Phrase }\end{array}$ & $\begin{array}{l}\text { Interface - EBSCOhost } \\
\text { Research Databases } \\
\text { Search Screen - Advanced } \\
\text { Search } \\
\text { Database - CINAHL Complete }\end{array}$ & Display \\
\hline
\end{tabular}




\begin{tabular}{|c|c|c|c|c|}
\hline S46 & "facit-f" & $\begin{array}{l}\text { Search modes - } \\
\text { Boolean/Phrase }\end{array}$ & $\begin{array}{l}\text { Interface - EBSCOhost } \\
\text { Research Databases } \\
\text { Search Screen - Advanced } \\
\text { Search } \\
\text { Database - CINAHL Complete }\end{array}$ & Display \\
\hline S45 & "mfsi-sf" & $\begin{array}{l}\text { Search modes - } \\
\text { Boolean/Phrase }\end{array}$ & $\begin{array}{l}\text { Interface - EBSCOhost } \\
\text { Research Databases } \\
\text { Search Screen - Basic Search } \\
\text { Database - CINAHL Complete }\end{array}$ & Display \\
\hline S44 & $\begin{array}{l}\text { "'sickness impact } \\
\text { profile"'" }\end{array}$ & $\begin{array}{l}\text { Search modes - } \\
\text { Boolean/Phrase }\end{array}$ & $\begin{array}{l}\text { Interface - EBSCOhost } \\
\text { Research Databases } \\
\text { Search Screen - Basic Search } \\
\text { Database - CINAHL Complete }\end{array}$ & Display \\
\hline$S 43$ & $\begin{array}{l}\text { (MH "Sickness Impact } \\
\text { Profile") }\end{array}$ & $\begin{array}{l}\text { Search modes - } \\
\text { Boolean/Phrase }\end{array}$ & $\begin{array}{l}\text { Interface - EBSCOhost } \\
\text { Research Databases } \\
\text { Search Screen - Basic Search } \\
\text { Database - CINAHL Complete }\end{array}$ & Display \\
\hline S42 & $\begin{array}{l}\text { "'liver disease symptom } \\
\text { index"'" }\end{array}$ & $\begin{array}{l}\text { Search modes - } \\
\text { Boolean/Phrase }\end{array}$ & $\begin{array}{l}\text { Interface - EBSCOhost } \\
\text { Research Databases } \\
\text { Search Screen - Basic Search } \\
\text { Database - CINAHL Complete }\end{array}$ & Display \\
\hline S41 & "LDSI" & $\begin{array}{l}\text { Search modes - } \\
\text { Boolean/Phrase }\end{array}$ & $\begin{array}{l}\text { Interface - EBSCOhost } \\
\text { Research Databases } \\
\text { Search Screen - Basic Search } \\
\text { Database - CINAHL Complete }\end{array}$ & Display \\
\hline$S 40$ & sf36 OR sf-36 & $\begin{array}{l}\text { Search modes - } \\
\text { Boolean/Phrase }\end{array}$ & $\begin{array}{l}\text { Interface - EBSCOhost } \\
\text { Research Databases } \\
\text { Search Screen - Basic Search } \\
\text { Database - CINAHL Complete }\end{array}$ & Display \\
\hline S39 & "'"short form 36"' & $\begin{array}{l}\text { Search modes - } \\
\text { Boolean/Phrase }\end{array}$ & $\begin{array}{l}\text { Interface - EBSCOhost } \\
\text { Research Databases } \\
\text { Search Screen - Basic Search } \\
\text { Database - CINAHL Complete }\end{array}$ & Display \\
\hline S38 & $\begin{array}{l}\text { (MH "Short Form-36 } \\
\text { Health Survey (SF-36)") }\end{array}$ & $\begin{array}{l}\text { Search modes - } \\
\text { Boolean/Phrase }\end{array}$ & $\begin{array}{l}\text { Interface - EBSCOhost } \\
\text { Research Databases } \\
\text { Search Screen - Basic Search } \\
\text { Database - CINAHL Complete }\end{array}$ & Display \\
\hline S37 & "short form 8" & $\begin{array}{l}\text { Search modes - } \\
\text { Boolean/Phrase }\end{array}$ & $\begin{array}{l}\text { Interface - EBSCOhost } \\
\text { Research Databases } \\
\text { Search Screen - Basic Search }\end{array}$ & Display \\
\hline
\end{tabular}




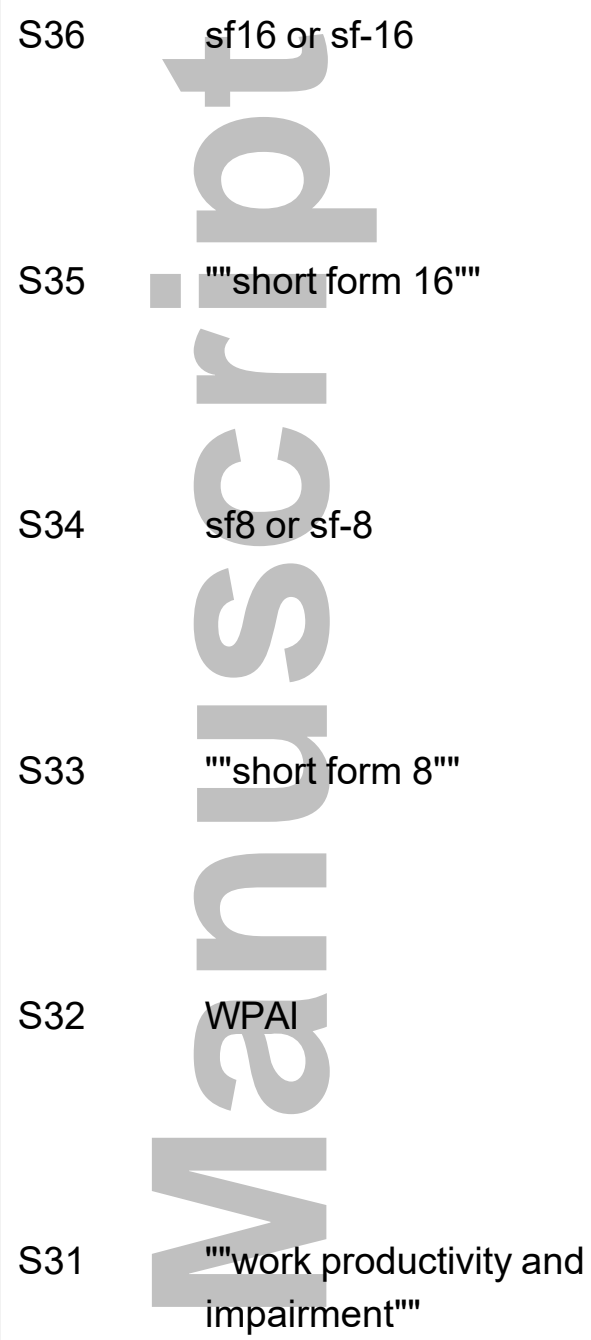

S30
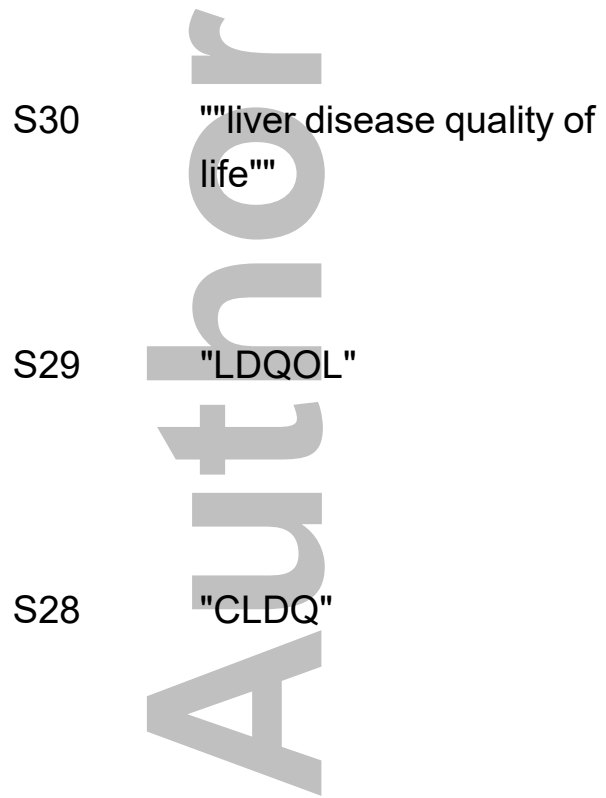

S27 "chronic liver disease questionnaire"

Search modes -

Search modes -

Boolean/Phrase

Boolean/Phrase

Search modes -

Boolean/Phrase

Search modes -

Boolean/Phrase

Search modes -

Boolean/Phrase

Database - CINAHL Complete

Interface - EBSCOhost

Display

Research Databases

Search Screen - Basic Search

Database - CINAHL Complete

Interface - EBSCOhost

Display

Research Databases

Search Screen - Basic Search

Database - CINAHL Complete

Interface - EBSCOhost

Display

Research Databases

Search Screen - Basic Search

Database - CINAHL Complete

Interface - EBSCOhost

Display

Research Databases

Search Screen - Basic Search

Database - CINAHL Complete

Interface - EBSCOhost

Display

Research Databases

Search Screen - Basic Search

Database - CINAHL Complete

Search modes -

Interface - EBSCOhost

Display

Boolean/Phrase

Search modes -

Boolean/Phrase

Search modes -

Boolean/Phrase

Search modes -

Boolean/Phrase

Search modes -

Boolean/Phrase
Interface - EBSCOhost

Display

Research Databases

Search Screen - Basic Search

Database - CINAHL Complete

Interface - EBSCOhost

Display

Research Databases

Search Screen - Basic Search

Database - CINAHL Complete

Interface - EBSCOhost

Display

Research Databases

Search Screen - Basic Search

Database - CINAHL Complete

Research Databases

Search Screen - Basic Search

Database - CINAHL Complete

Interface - EBSCOhost

Display

Search Screen - Basic Search 
(S1 OR S2 OR S3 OR S4

OR S5 OR S6 OR S7 OR S8 OR S9 OR S10 OR S11 OR S12 OR S13 OR S14 OR S15 OR S16 OR

S17 OR S18 OR S19 OR S20 OR S21 OR S22 OR S23 OR S24 OR S25)

$\mathrm{S} 25$
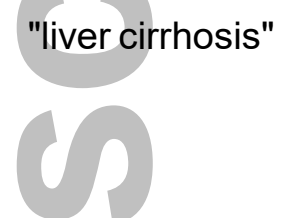

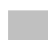

S24 (MH "Liver Cirrhosis+")

S23
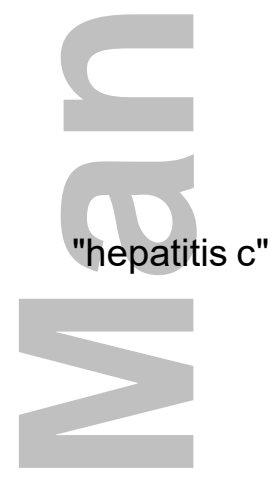

S22

"hepatitis b"

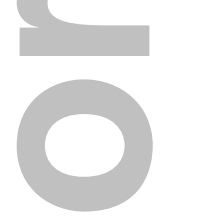

S21
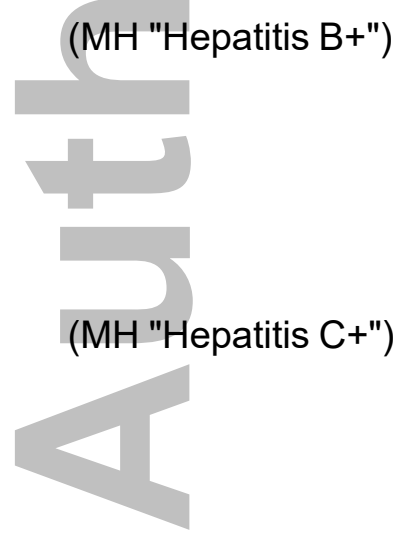

S20

(MH "Liver Diseases, Alcoholic+")
Search modes -

Boolean/Phrase

Search modes -

Boolean/Phrase

Search modes -

Boolean/Phrase

Search modes -

Boolean/Phrase

Search modes -

Boolean/Phrase

Search modes -

Boolean/Phrase

Search modes -

Boolean/Phrase

Search modes -

Boolean/Phrase
Database - CINAHL Complete

Interface - EBSCOhost

Display

Research Databases

Search Screen - Advanced

Search

Database - CINAHL Complete

Interface - EBSCOhost

Display

Research Databases

Search Screen - Advanced

Search

Database - CINAHL Complete

Interface - EBSCOhost

Display

Research Databases

Search Screen - Advanced

Search

Database - CINAHL Complete

Interface - EBSCOhost

Research Databases

Search Screen - Advanced

Search

Database - CINAHL Complete

Interface - EBSCOhost

Display

Research Databases

Search Screen - Advanced

Search

Database - CINAHL Complete

Interface - EBSCOhost

Display

Research Databases

Search Screen - Advanced

Search

Database - CINAHL Complete

Interface - EBSCOhost

Display

Research Databases

Search Screen - Advanced

Search

Database - CINAHL Complete

Interface - EBSCOhost

Display

Display

\section{Hepatology}

This article is protected by copyright. All rights reserved. 
Search Screen - Advanced

Search

Database - CINAHL Complete

$\mathrm{S} 18$



Search modes -

Interface - EBSCOhost

Display

Boolean/Phrase

Research Databases

Search Screen - Advanced

Search
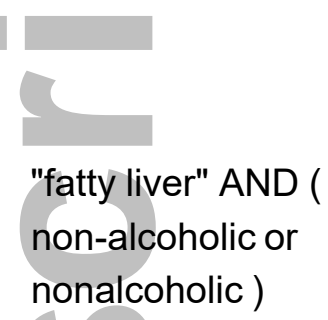

S16

(MH "Nonalcoholic Fatty Liver Disease")



S15

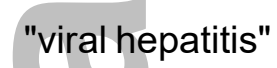

S14

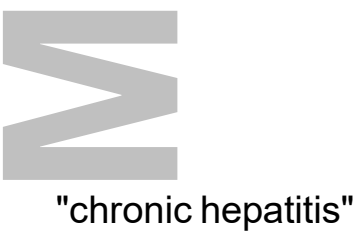

S13

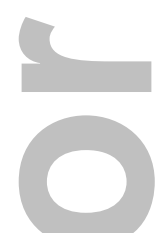

(MH "Hepatitis, Viral, Human")



S12

(MH "Hepatitis, Chronic")



S11
(MH "Hepatorenal Syndrome") OR "Hepatorenal Syndrome"
Search modes -

Boolean/Phrase

Search modes -

Boolean/Phrase

Search modes -

Boolean/Phrase

Search modes -

Boolean/Phrase

Search modes -

Boolean/Phrase

Search modes -

Boolean/Phrase

Database - CINAHL Complete

Interface - EBSCOhost

Research Databases

Search Screen - Advanced

Search

Database - CINAHL Complete

Interface - EBSCOhost

Display

Research Databases

Search Screen - Advanced

Search

Database - CINAHL Complete

Interface - EBSCOhost

Display

Research Databases

Search Screen - Advanced

Search

Database - CINAHL Complete

Interface - EBSCOhost

Display

Research Databases

Search Screen - Advanced

Search

Database - CINAHL Complete

Interface - EBSCOhost

Display

Research Databases

Search Screen - Advanced

Search

Database - CINAHL Complete

Interface - EBSCOhost

Display

Research Databases

Search Screen - Advanced

Search

Database - CINAHL Complete

Interface - EBSCOhost

Display

Research Databases

Search Screen - Advanced 


\begin{tabular}{|c|c|c|c|c|}
\hline \multirow[b]{2}{*}{ S10 } & & & $\begin{array}{l}\text { Search } \\
\text { Database - CINAHL Complete }\end{array}$ & \multirow[b]{2}{*}{ Display } \\
\hline & $\begin{array}{l}\text { (MH "Hepatopulmonary } \\
\text { Syndrome") OR } \\
\text { "Hepatopulmonary } \\
\text { Syndrome" }\end{array}$ & $\begin{array}{l}\text { Search modes - } \\
\text { Boolean/Phrase }\end{array}$ & $\begin{array}{l}\text { Interface - EBSCOhost } \\
\text { Research Databases } \\
\text { Search Screen - Advanced } \\
\text { Search } \\
\text { Database - CINAHL Complete }\end{array}$ & \\
\hline s9 & $\begin{array}{l}\text { (MH } \\
\text { "Cholangiocarcinoma") } \\
\text { OR } \\
\text { "Cholangiocarcinoma" }\end{array}$ & $\begin{array}{l}\text { Search modes - } \\
\text { Boolean/Phrase }\end{array}$ & $\begin{array}{l}\text { Interface - EBSCOhost } \\
\text { Research Databases } \\
\text { Search Screen - Advanced } \\
\text { Search } \\
\text { Database - CINAHL Complete }\end{array}$ & Display \\
\hline S8 & cirrhosis & $\begin{array}{l}\text { Search modes - } \\
\text { Boolean/Phrase }\end{array}$ & $\begin{array}{l}\text { Interface - EBSCOhost } \\
\text { Research Databases } \\
\text { Search Screen - Advanced } \\
\text { Search } \\
\text { Database - CINAHL Complete }\end{array}$ & Display \\
\hline S7 & HBV & $\begin{array}{l}\text { Search modes - } \\
\text { Boolean/Phrase }\end{array}$ & $\begin{array}{l}\text { Interface - EBSCOhost } \\
\text { Research Databases } \\
\text { Search Screen - Advanced } \\
\text { Search } \\
\text { Database - CINAHL Complete }\end{array}$ & Display \\
\hline S6 & "HC & $\begin{array}{l}\text { Search modes - } \\
\text { Boolean/Phrase }\end{array}$ & $\begin{array}{l}\text { Interface - EBSCOhost } \\
\text { Research Databases } \\
\text { Search Screen - Advanced } \\
\text { Search } \\
\text { Database - CINAHL Complete }\end{array}$ & Display \\
\hline S5 & $\begin{array}{l}\text { vanced liver } \\
\text { ase }^{* \text { "'" }}\end{array}$ & $\begin{array}{l}\text { Search modes - } \\
\text { Boolean/Phrase }\end{array}$ & $\begin{array}{l}\text { Interface - EBSCOhost } \\
\text { Research Databases } \\
\text { Search Screen - Basic Search } \\
\text { Database - CINAHL Complete }\end{array}$ & Display \\
\hline S4 & "chronic liver disease*" & $\begin{array}{l}\text { Search modes - } \\
\text { Boolean/Phrase }\end{array}$ & $\begin{array}{l}\text { Interface - EBSCOhost } \\
\text { Research Databases } \\
\text { Search Screen - Basic Search } \\
\text { Database - CINAHL Complete }\end{array}$ & Display \\
\hline S3 & & $\begin{array}{l}\text { Search modes - } \\
\text { Boolean/Phrase }\end{array}$ & $\begin{array}{l}\text { Interface - EBSCOhost } \\
\text { Research Databases } \\
\text { Search Screen - Advanced } \\
\text { Search } \\
\text { Database - CINAHL Complete }\end{array}$ & Display \\
\hline
\end{tabular}

This article is protected by copyright. All rights reserved. 
http://web.a.ebscohost.com/ehost/searchhistory/PrintSearchHistory?sid=...

S2



Search modes -

Boolean/Phrase

Interface - EBSCOhost

Display

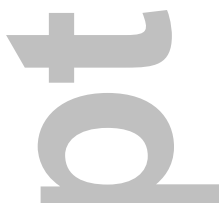

S1

(MH "Carcinoma,

Hepatocellular") OR

"Carcinoma,

Hepatocellular"

Research Databases

Search Screen - Advanced

Search

Database - CINAHL Complete

Search modes -

Interface - EBSCOhost

Display

Boolean/Phrase

Research Databases

Search Screen - Advanced

Search

Database - CINAHL Complete

Hepatology

This article is protected by copyright. All rights reserved. 


\section{Embase $^{\odot}$}

\section{Embase Session Results}

\begin{tabular}{|c|c|c|}
\hline No. & Query & Results \\
\hline \#78 & \#77 AND [embase]/lim NOT [medline]/lim & 1,367 \\
\hline \#77 & \#45 AND \#76 AND [english]/lim & 2,480 \\
\hline$\# 76$ & $\begin{array}{l}\text { \#46 OR \#47 OR \#48 OR \#49 OR \#50 OR \#5I OR \#52 OR \#53 OR \#54 OR \#55 OR \#56 OR \#57 OR \#58 OR \#59 OR \#60 OR \#6I OR \#62 OR \#63 } \\
\text { OR\#64 OR \#65 OR \#66 OR \#67 OR\#68 OR \#7I OR\#74 OR\#75 }\end{array}$ & 533,520 \\
\hline \#75 & 'alcohol liver disease'/exp & 21,712 \\
\hline$\# 74$ & \#72 AND \#73 & 25,228 \\
\hline \#73 & 'liver disease*' & 218,250 \\
\hline \#72 & alcoholic & 76,230 \\
\hline \#71 & \#69 AND \#70 & 12,540 \\
\hline$\# 70$ & 'fatty liver' & 55,751 \\
\hline$\# 69$ & 'non alcoholic' & 15,540 \\
\hline$\# 68$ & 'nonalcoholic fatty liver'/exp & 24,771 \\
\hline$\# 67$ & 'viral hepatitis' & 31,106 \\
\hline$\# 66$ & 'chronic hepatitis' & 71,312 \\
\hline$\# 65$ & 'virus hepatitis'/de & 22,173 \\
\hline$\# 64$ & 'chronic hepatitis'/de & 26,907 \\
\hline$\# 63$ & 'hepatorenal syndrome'/exp & 4,306 \\
\hline$\# 62$ & 'hepatopulmonary syndrome' & 1,711 \\
\hline$\# 61$ & 'hepatopulmonary syndrome'/exp & 1,539 \\
\hline$\# 60$ & cholangiocarcinoma & 14,164 \\
\hline$\# 59$ & 'bile duct carcinoma'/exp & 20,583 \\
\hline \#58 & cirrhosis & 172,202 \\
\hline$\# 57$ & 'liver cirrhosis'/exp & 149,194 \\
\hline$\# 56$ & 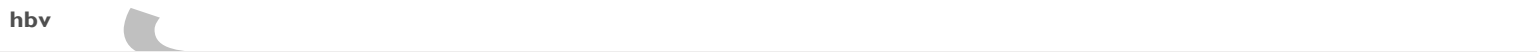 & 54,704 \\
\hline$\# 55$ & 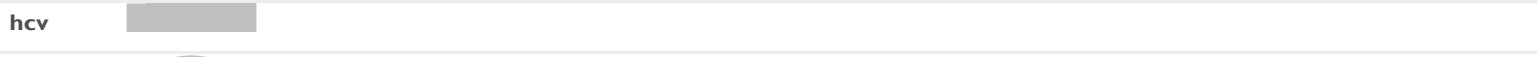 & 77,990 \\
\hline$\# 54$ & 'hepatitis b' & 137,857 \\
\hline \#53 & 'hepatitis b'/exp & 85,830 \\
\hline$\# 52$ & 'hepatitis c' & 124,084 \\
\hline$\# 51$ & 'hepatitis $c /$ exp & 93,426 \\
\hline$\# 50$ & 'advanced liver disease ${ }^{* '}: t i, a b$ & 2,713 \\
\hline$\# 49$ & 'chronic liver disease*':ti,ab & 24,450 \\
\hline$\# 48$ & hec & 62,613 \\
\hline$\# 47$ & 'hepatocellular carcinoma' & 94,416 \\
\hline$\# 46$ & 'liver cell carcinoma'/exp OR 'liver cell carcinoma' & 127,949 \\
\hline$\# 45$ & $\begin{array}{l}\# 1 \text { OR \#2 OR \#3 OR \#4 OR \#5 OR \#6 OR \#7 OR \#8 OR \#9 OR \#10 OR \#1 I OR \#12 OR \#13 OR \#14 OR \#15 OR \#16 OR \#17 OR \#18 OR \#19 OR } \\
\text { \#20 OR \#2I OR \#22 OR \#23 OR \#24 OR \#25 OR \#26 OR \#27 OR \#28 OR \#29 OR \#30 OR \#3I OR \#32 OR \#33 OR \#34 OR \#35 OR \#42 OR \#43 } \\
\text { OR \#44 }\end{array}$ & 189,231 \\
\hline$\# 44$ & 'quality of life'/mj & 76,693 \\
\hline$\# 43$ & 'outcome assessment'/mj & 16,320 \\
\hline$\# 42$ & \#36 AND \#4I & 40,747 \\
\hline$\# 41$ & $\# 37$ OR \#38 OR \#39 OR \#40 & $5,070,192$ \\
\hline$\# 40$ & 'quality of life' & 414,220 \\
\hline$\# 39$ & measure*:ab,ti & $3,479,388$ \\
\hline$\# 38$ & Hepatology & $1,765,328$ \\
\hline
\end{tabular}




\section{Embase}

\begin{tabular}{|c|c|c|}
\hline$\# 35$ & qol & 50,402 \\
\hline$\# 34$ & 'health related quality of life' & 44,542 \\
\hline$\# 33$ & hrqol & 17,561 \\
\hline \#32 & 'patient-reported outcome'/exp & 2,887 \\
\hline$\# 31$ & 'patient reported outcome measure'/exp & 120 \\
\hline \#30 & 'euroqol 5d' & 1,498 \\
\hline \#29 & 'euroqol 5d questionnaire'/exp & 41 \\
\hline \#28 & nhp & 3,289 \\
\hline \#27 & 'nottingham health profile'/exp & 322 \\
\hline \#26 & 'multi-dimensional fatigue inventory' & 20 \\
\hline \#25 & 'short form $6 \mathrm{~d}$ '/exp & 131 \\
\hline$\# 24$ & 'sf 6d' & 1,020 \\
\hline$\# 23$ & 'facit f' & 465 \\
\hline \#22 & 'mfsi sf' & 67 \\
\hline$\# 21$ & 'sickness impact profile'/exp & 2,038 \\
\hline$\# 20$ & Idsi & 20 \\
\hline$\# 19$ & 'liver disease symptom index' & 17 \\
\hline$\# 18$ & 'short form 36 '/exp & 22,249 \\
\hline$\# 17$ & sf36 & 2,542 \\
\hline \#16 & 'sf 36' & 26,162 \\
\hline \#15 & sf 16 & 5 \\
\hline \#14 & 'sf 16' & 43 \\
\hline$\# 13$ & 'short form 16' & 6 \\
\hline$\# 12$ & 'sf 8' & 525 \\
\hline \#II & sf8 & 70 \\
\hline \#10 & 'short form 8' & 340 \\
\hline \#9 & 'short form 8'/exp & 287 \\
\hline \#8 & wpai & 922 \\
\hline \#7 & 'work productivity and activity impairment' & 920 \\
\hline \#6 & 'work productivity and activity impairment questionnaire'/exp & 61 \\
\hline \#5 & 'liver disease quality of life' & 43 \\
\hline$\# 4$ & Idqol & 35 \\
\hline \#3 & cldq & 205 \\
\hline$\# 2$ & 'chronic liver disease questionnaire' & 192 \\
\hline \#I & 'chronic liver disease questionnaire'/exp & 36 \\
\hline
\end{tabular}

\section{ELSEVIER}

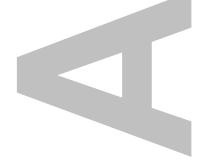

@2017RELXIntellectual PropertiesSA.All rights reserved.

Embase, RELX Group and the RE symbol are trade marks of RELX Intellectual Properties SA, used under license. 


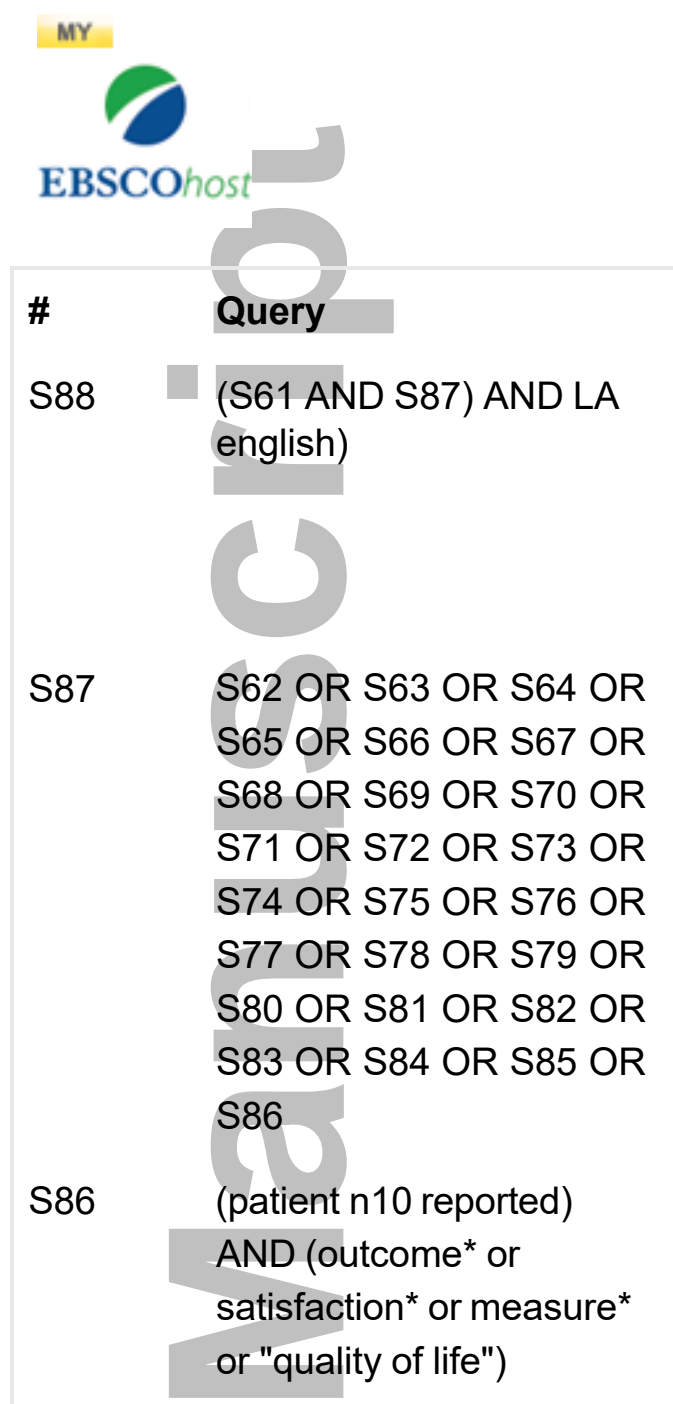

Monday, May 01, 2017 10:06:10 AM

S85 "health related quality of

Search modes -

Search modes -

Boolean/Phrase

Limiters/Expanders

Search modes Boolean/Phrase

Search modes Boolean/Phrase Boolean/Phrase

S84 QOL

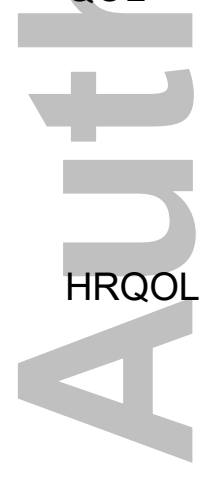

Search modes Boolean/Phrase

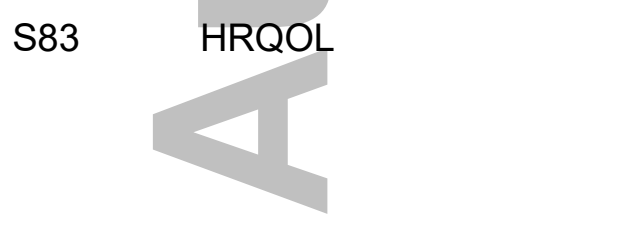

Search modes Boolean/Phrase

S82 DE "Quality of Life"

\section{Last Run Via \\ Interface - EBSCOhost \\ Research Databases}

Search Screen - Advanced

Search

Database - PsycINFO

Interface - EBSCOhost

Research Databases

Search Screen - Advanced

Search

Database - PsycINFO
Results

320

Display

Interface - EBSCOhost

Research Databases

Search Screen - Advanced

Search

Database - PsycINFO

Interface - EBSCOhost

Display

Research Databases

Search Screen - Advanced

Search

Database - PsycINFO

Interface - EBSCOhost

Display

Research Databases

Search Screen - Advanced

Search

Database - PsycINFO

Interface - EBSCOhost

Research Databases

Search Screen - Advanced

Search

Database - PsycINFO

Interface - EBSCOhost

Research Databases

Display
Search modes -

Boolean/Phrase 
Search Screen - Advanced

Search

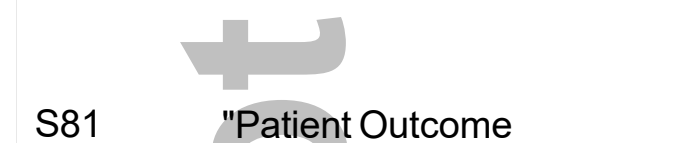

S81 Patient Outcome
Assessment"

Search modes -

Database - PsycINFO

Boolean/Phrase

Interface - EBSCOhost

Display

Research Databases

Search Screen - Advanced

Search

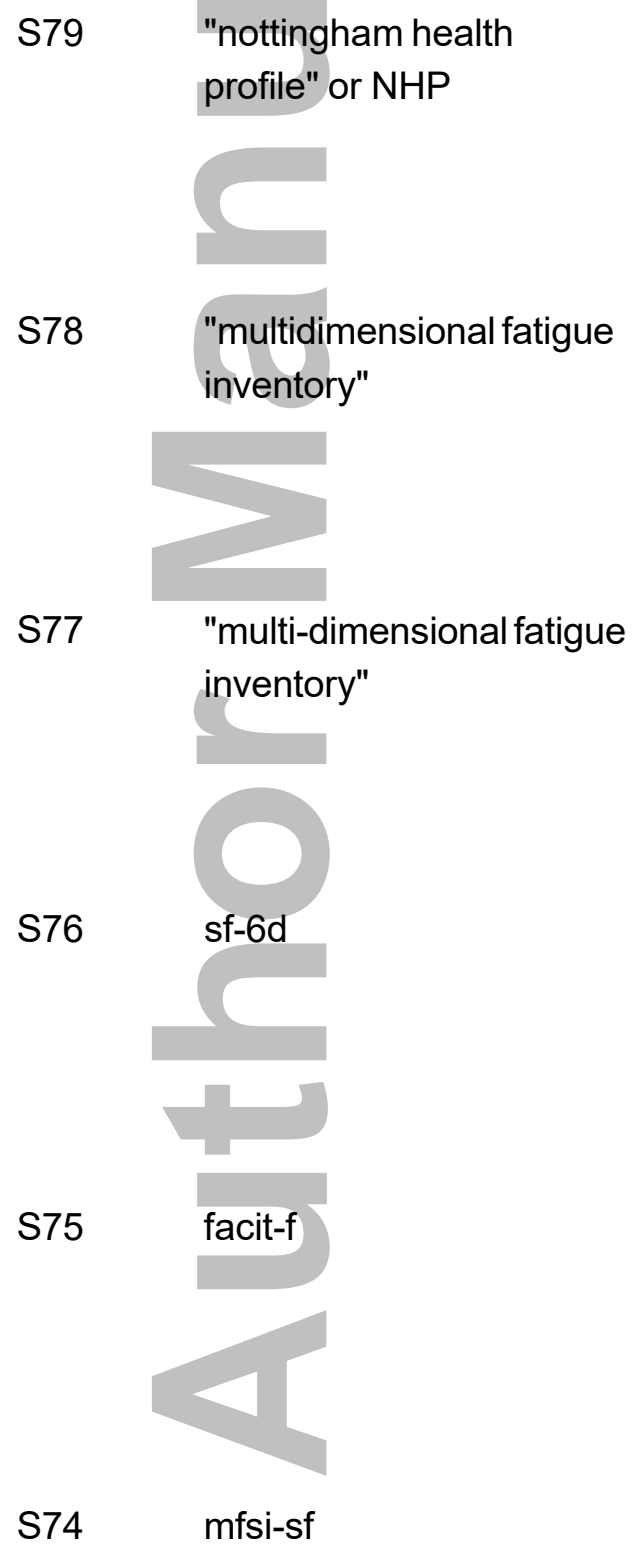

Search modes -

Search modes -

$\mathrm{S} 80$

$\begin{array}{ll}\text { EuroQOL-5D } & \text { Search modes - } \\ \text { Boolean/Phrase }\end{array}$

Boolean/Phrase

Search modes -

Boolean/Phrase

Search modes -

Boolean/Phrase

Search modes -

Boolean/Phrase

Search modes -

Boolean/Phrase

Search modes -

Boolean/Phrase

Database - PsycINFO

Interface - EBSCOhost

Research Databases

Search Screen - Advanced

Search

Database - PsycINFO

Interface - EBSCOhost

Research Databases

Search Screen - Advanced

Search

Database - PsycINFO

Interface - EBSCOhost

Research Databases

Search Screen - Advanced

Search

Database - PsycINFO

Interface - EBSCOhost

Research Databases

Search Screen - Advanced

Search

Database - PsycINFO

Interface - EBSCOhost

Research Databases

Search Screen - Advanced

Search

Database - PsycINFO

Interface - EBSCOhost

Research Databases

Search Screen - Advanced

Search

Database - PsycINFO

Interface - EBSCOhost

Research Databases

Search Screen - Advanced

Display

Display

Display

Display

Display 


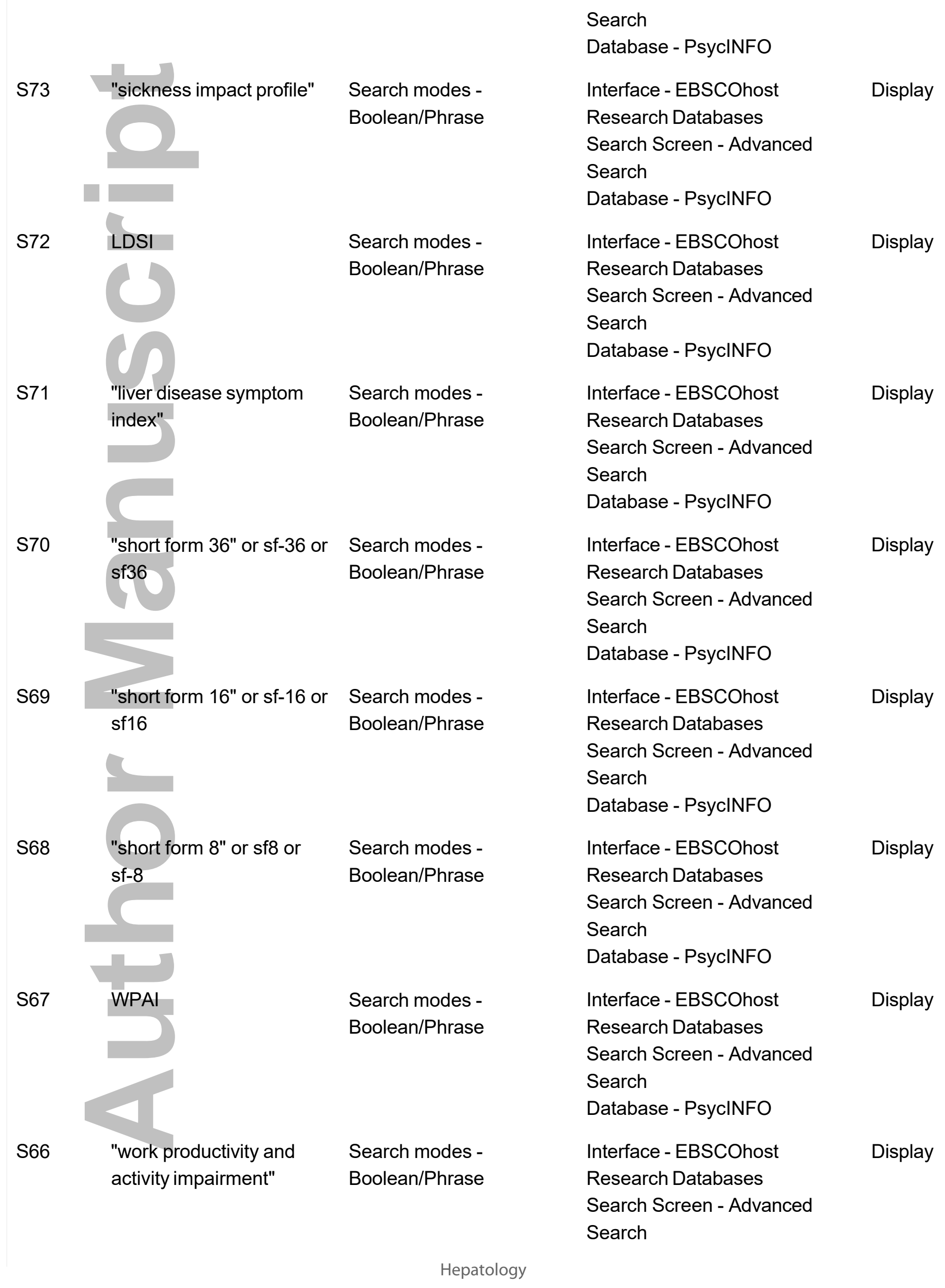

This article is protected by copyright. All rights reserved. 
"liver disease quality of life"


questionnaire

S61

(S45 OR S46 OR S47 OR S48 OR S49 OR S50 OR S51 OR S52 OR S53 OR S54 OR S55 OR S56 OR S57 OR S58 OR S59 OR S60)

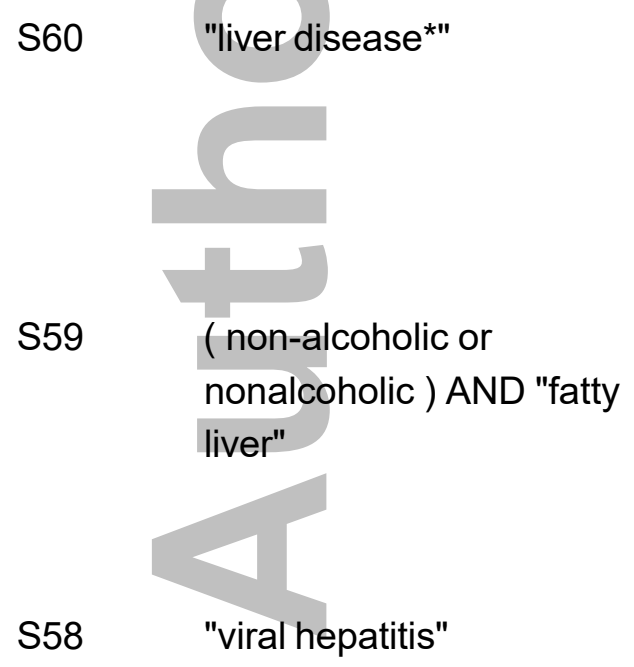

\begin{abstract}
Search modes -
Boolean/Phrase
\end{abstract}

Search modes -

Boolean/Phrase

Search modes -

Boolean/Phrase

Search modes -

Boolean/Phrase

Search modes -

Boolean/Phrase

Search modes -

Boolean/Phrase

Search modes -

Boolean/Phrase
Database - PsycINFO

Interface - EBSCOhost

Research Databases

Search Screen - Advanced

Search

Database - PsycINFO

Interface - EBSCOhost

Research Databases

Search Screen - Advanced

Search

Database - PsycINFO

Interface - EBSCOhost

Research Databases

Search Screen - Advanced

Search

Database - PsycINFO

Interface - EBSCOhost

Research Databases

Search Screen - Advanced

Search

Database - PsycINFO

Interface - EBSCOhost

Research Databases

Search Screen - Advanced

Search

Database - PsycINFO

Interface - EBSCOhost

Research Databases

Search Screen - Advanced

Search

Database - PsycINFO

Interface - EBSCOhost

Research Databases

Search Screen - Advanced

Search

Database - PsycINFO

Interface - EBSCOhost

Research Databases

Search Screen - Advanced

Search
Display

Display

Display

Display

Display

Display

Display

Display 
S57
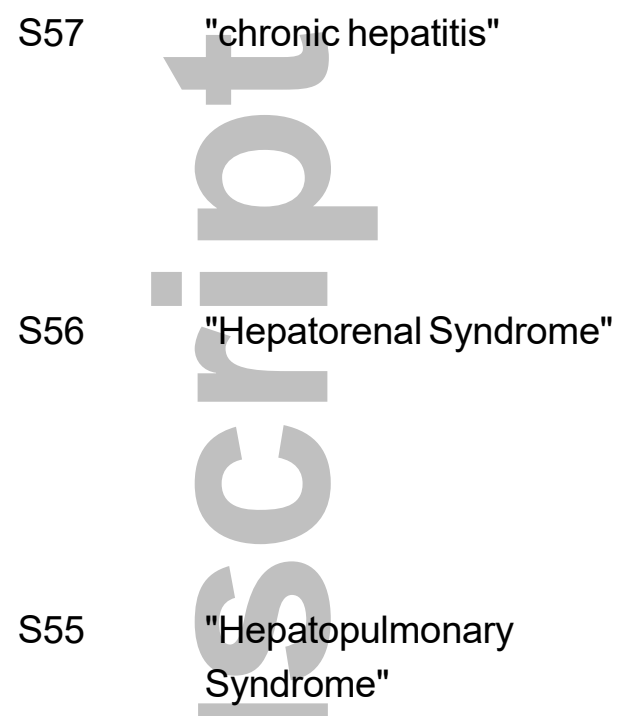

S53

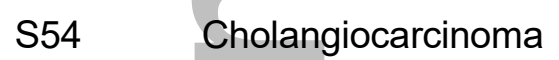

S52

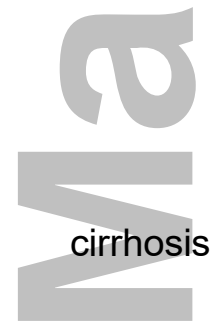

S51

S50
Search modes -
Boolean/Phrase

Search modes -

Boolean/Phrase

Search modes -

Boolean/Phrase

Search modes -

Boolean/Phrase

Search modes -

Boolean/Phrase

Search modes -

Boolean/Phrase

Search modes -

Boolean/Phrase

Search modes -

Boolean/Phrase
Database - PsycINFO

Interface - EBSCOhost

Research Databases

Search Screen - Advanced

Search

Database - PsycINFO

Interface - EBSCOhost

Research Databases

Search Screen - Advanced

Search

Database - PsycINFO

Interface - EBSCOhost

Research Databases

Search Screen - Advanced

Search

Database - PsycINFO

Interface - EBSCOhost

Research Databases

Search Screen - Advanced

Search

Database - PsycINFO

Interface - EBSCOhost

Research Databases

Search Screen - Advanced

Search

Database - PsycINFO

Interface - EBSCOhost

Research Databases

Search Screen - Advanced

Search

Database - PsycINFO

Interface - EBSCOhost

Research Databases

Search Screen - Advanced

Search

Database - PsycINFO

Interface - EBSCOhost

Research Databases

Search Screen - Advanced

Search

Database - PsycINFO

Display

Display

Display

Display

Display

Display 


\begin{tabular}{|c|c|c|c|c|}
\hline S49 & "hepatitis c" & $\begin{array}{l}\text { Search modes - } \\
\text { Boolean/Phrase }\end{array}$ & $\begin{array}{l}\text { Interface - EBSCOhost } \\
\text { Research Databases } \\
\text { Search Screen - Advanced } \\
\text { Search } \\
\text { Database - PsycINFO }\end{array}$ & Display \\
\hline S48 & DE "Hepatitis" & $\begin{array}{l}\text { Search modes - } \\
\text { Boolean/Phrase }\end{array}$ & $\begin{array}{l}\text { Interface - EBSCOhost } \\
\text { Research Databases } \\
\text { Search Screen - Advanced } \\
\text { Search } \\
\text { Database - PsycINFO }\end{array}$ & Display \\
\hline S47 & DE "Cirrhosis (Liver)" & $\begin{array}{l}\text { Search modes - } \\
\text { Boolean/Phrase }\end{array}$ & $\begin{array}{l}\text { Interface - EBSCOhost } \\
\text { Research Databases } \\
\text { Search Screen - Advanced } \\
\text { Search } \\
\text { Database - PsycINFO }\end{array}$ & Display \\
\hline S46 & & $\begin{array}{l}\text { Search modes - } \\
\text { Boolean/Phrase }\end{array}$ & $\begin{array}{l}\text { Interface - EBSCOhost } \\
\text { Research Databases } \\
\text { Search Screen - Advanced } \\
\text { Search } \\
\text { Database - PsycINFO }\end{array}$ & Display \\
\hline S45 & $\begin{array}{l}\text { "hepatocellular } \\
\text { Carcinoma" }\end{array}$ & $\begin{array}{l}\text { Search modes - } \\
\text { Boolean/Phrase }\end{array}$ & $\begin{array}{l}\text { Interface - EBSCOhost } \\
\text { Research Databases } \\
\text { Search Screen - Advanced } \\
\text { Search } \\
\text { Database - PsycINFO }\end{array}$ & Display \\
\hline S44 & $\begin{array}{l}\text { (S17 AND S43) AND LA } \\
\text { english) }\end{array}$ & $\begin{array}{l}\text { Search modes - } \\
\text { Boolean/Phrase }\end{array}$ & $\begin{array}{l}\text { Interface - EBSCOhost } \\
\text { Research Databases } \\
\text { Search Screen - Advanced } \\
\text { Search } \\
\text { Database - PsycINFO }\end{array}$ & 320 \\
\hline S43 & $\begin{array}{l}\text { S18 OR S19 OR S20 OR } \\
\text { S21 OR S22 OR S23 OR } \\
\text { S24 OR S25 OR S26 OR } \\
\text { S27 OR S28 OR S29 OR } \\
\text { S30 OR S31 OR S32 OR } \\
\text { S33 OR S34 OR S35 OR } \\
\text { S36 OR S37 OR S38 OR } \\
\text { S39 OR S40 OR S41 OR } \\
\text { S42 }\end{array}$ & $\begin{array}{l}\text { Search modes - } \\
\text { Boolean/Phrase }\end{array}$ & $\begin{array}{l}\text { Interface - EBSCOhost } \\
\text { Research Databases } \\
\text { Search Screen - Advanced } \\
\text { Search } \\
\text { Database - PsycINFO }\end{array}$ & 66,002 \\
\hline S42 & $\begin{array}{l}\text { (patient n10 reported) } \\
\text { AND (outcome* or } \\
\text { satisfaction }^{*} \text { or measure* }\end{array}$ & $\begin{array}{r}\text { Search modes - } \\
\text { Boolean/Phrase } \\
\text { Hepato }\end{array}$ & $\begin{array}{l}\text { Interface - EBSCOhost } \\
\text { Research Databases } \\
\text { Search Screen - Advanced }\end{array}$ & Display \\
\hline
\end{tabular}

This article is protected by copyright. All rights reserved. 


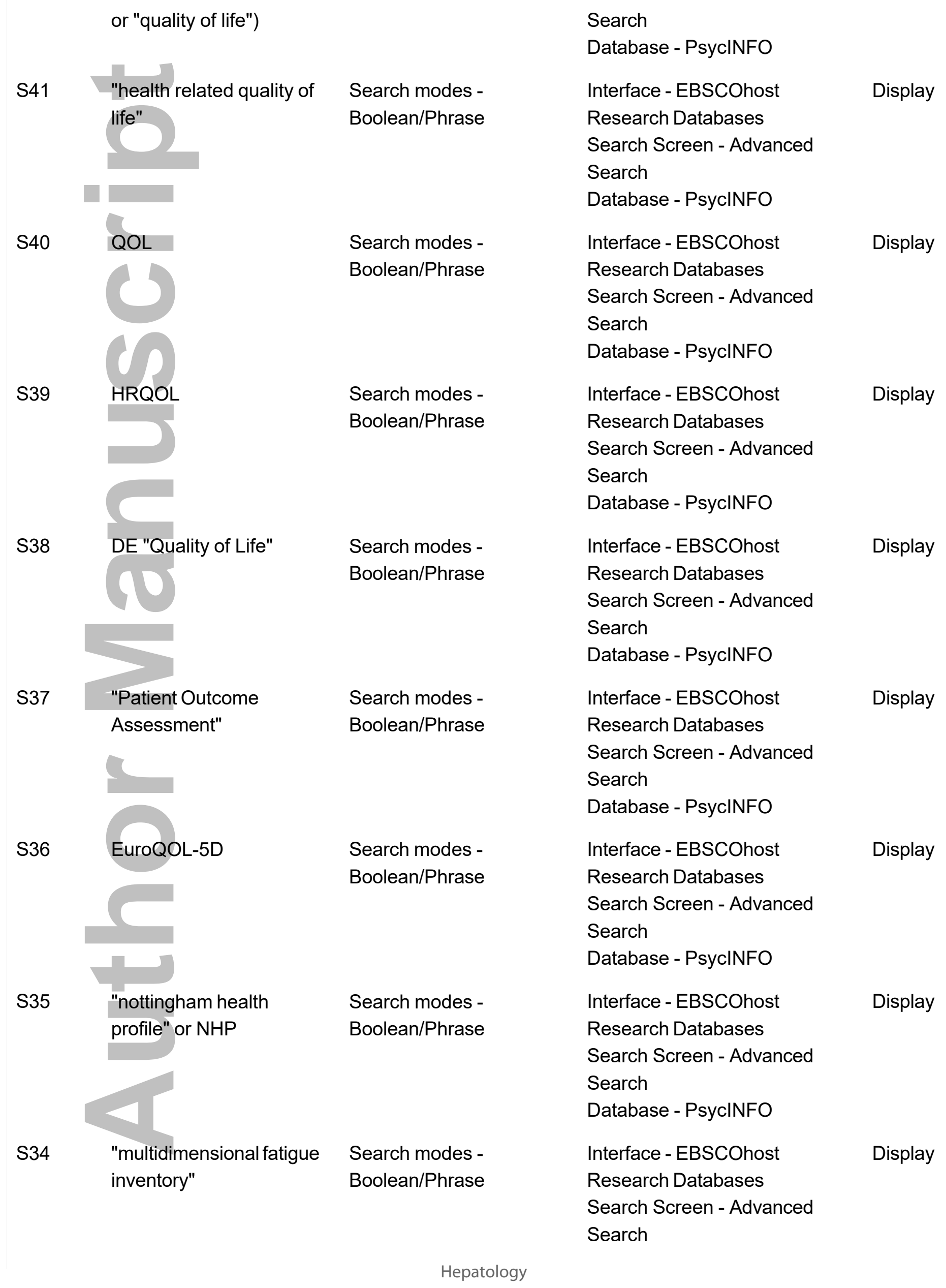

This article is protected by copyright. All rights reserved. 
2

3

4

5

6

7
S33

"multi-dimensional fatigue
inventory"
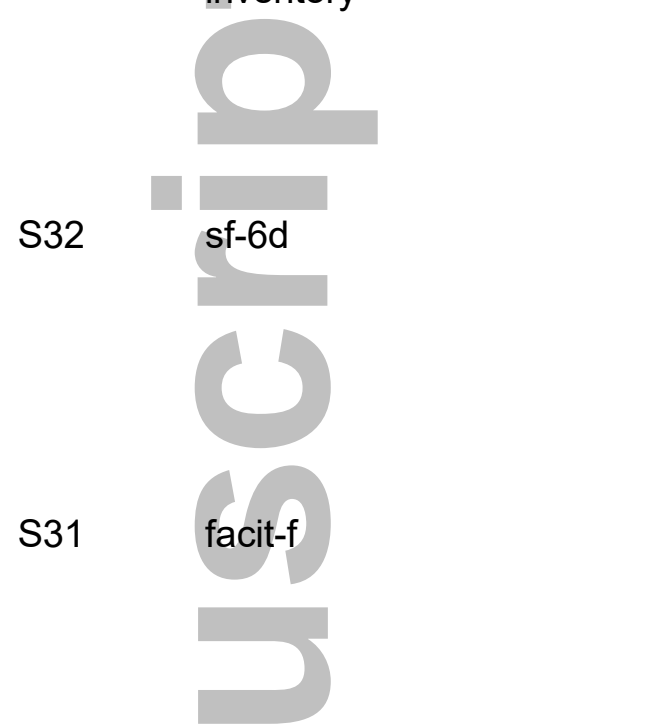

S30

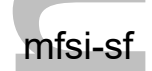

S29
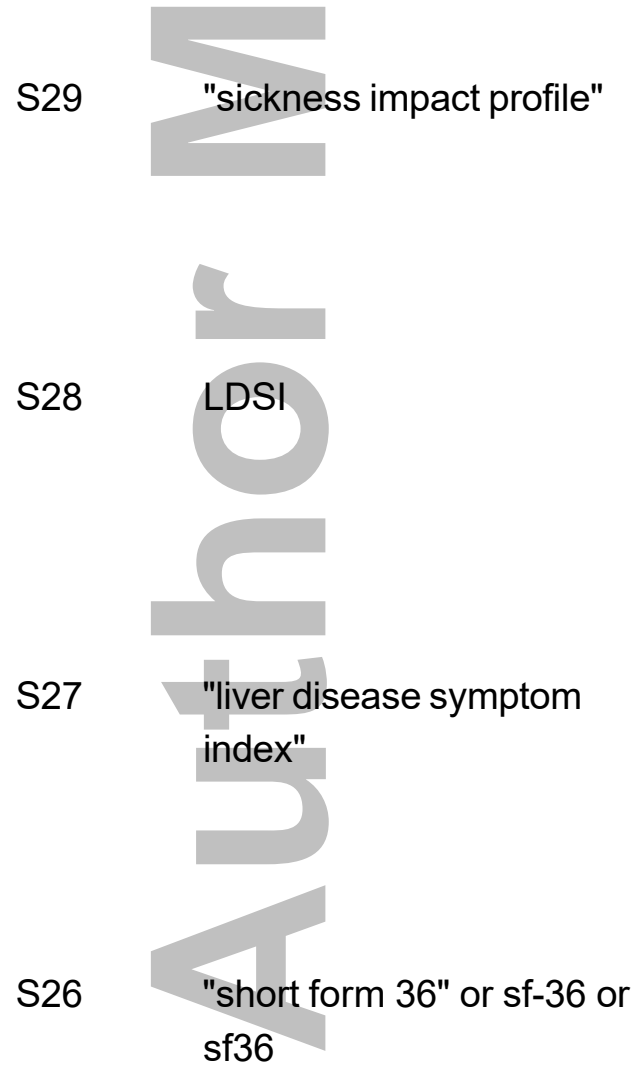

Search modes -

Boolean/Phrase

Search modes -

Boolean/Phrase

Search modes -

Boolean/Phrase

Search modes -

Boolean/Phrase

Search modes -

Boolean/Phrase

Search modes -

Boolean/Phrase

Search modes -

Boolean/Phrase

Search modes -

Boolean/Phrase
Database - PsycINFO

Interface - EBSCOhost

Research Databases

Search Screen - Advanced

Search

Database - PsycINFO

Interface - EBSCOhost

Research Databases

Search Screen - Advanced

Search

Database - PsycINFO

Interface - EBSCOhost

Research Databases

Search Screen - Advanced

Search

Database - PsycINFO

Interface - EBSCOhost

Research Databases

Search Screen - Advanced

Search

Database - PsycINFO

Interface - EBSCOhost

Research Databases

Search Screen - Advanced

Search

Database - PsycINFO

Interface - EBSCOhost

Research Databases

Search Screen - Advanced

Search

Database - PsycINFO

Interface - EBSCOhost

Research Databases

Search Screen - Advanced

Search

Database - PsycINFO

Interface - EBSCOhost

Research Databases

Search Screen - Advanced

Search

Database - PsycINFO

Display

Display

Display

Display

Display

Display 


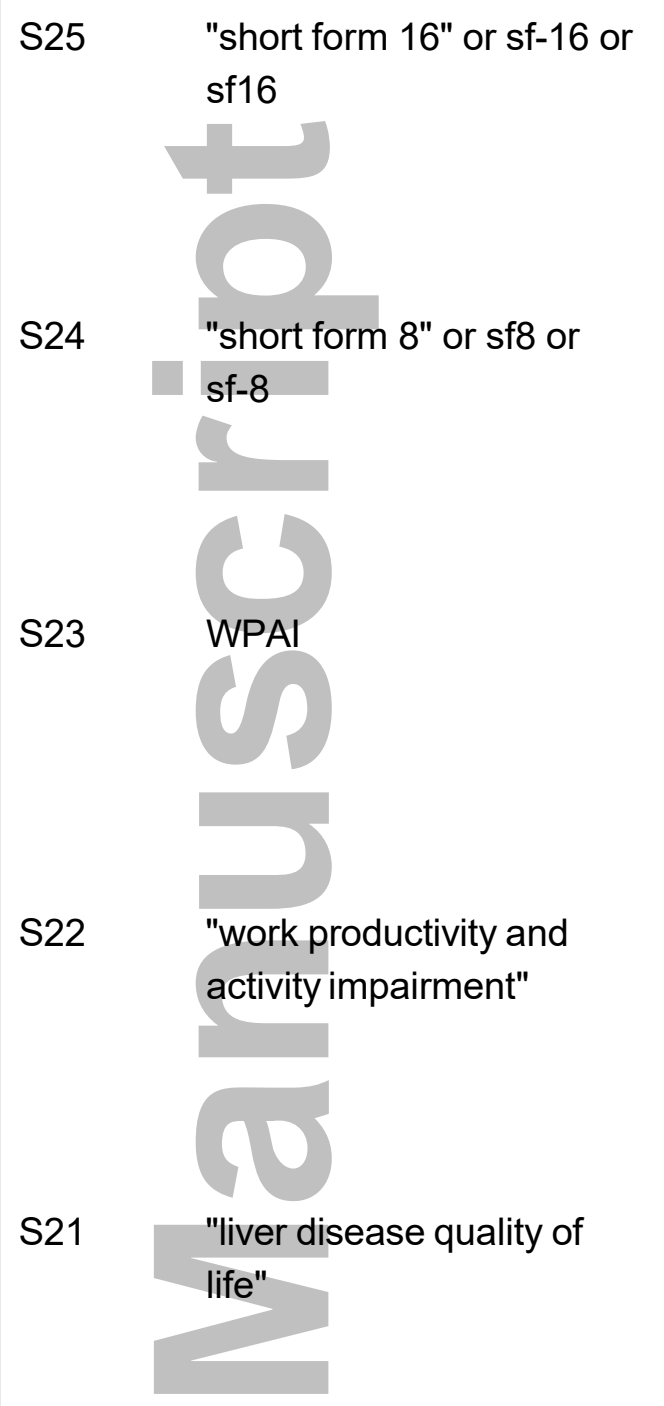

Search modes -

Boolean/Phrase

Search modes -

Boolean/Phrase

Search modes -

Boolean/Phrase

Search modes -

Boolean/Phrase

Search modes -

Boolean/Phrase

Search modes -

Boolean/Phrase

Search modes -

Boolean/Phrase

Search modes -

Boolean/Phrase
Interface - EBSCOhost

Research Databases

Search Screen - Advanced

Search

Database - PsycINFO

Interface - EBSCOhost

Research Databases

Search Screen - Advanced

Search

Database - PsycINFO

Interface - EBSCOhost

Research Databases

Search Screen - Advanced

Search

Database - PsycINFO

Interface - EBSCOhost

Research Databases

Search Screen - Advanced

Search

Database - PsycINFO

Interface - EBSCOhost

Research Databases

Search Screen - Advanced

Search

Database - PsycINFO

Interface - EBSCOhost

Research Databases

Search Screen - Advanced

Search

Database - PsycINFO

Interface - EBSCOhost

Research Databases

Search Screen - Advanced

Search

Database - PsycINFO

Interface - EBSCOhost

Research Databases

Search Screen - Advanced

Search

Database - PsycINFO

Display

Display

Display

Display

S18 chronic liver disease
questionnaire"

Hepatology
90
12

Display

Display

Display

Display

Display 




Search modes -

Boolean/Phrase

S8 OR S9 OR S10 OR

S11 OR S12 OR S13 OR

S14 OR S15 OR S16)

Search modes -

Boolean/Phrase

Search modes -

Boolean/Phrase

Search modes -

Boolean/Phrase

Search modes -

Boolean/Phrase

Search modes -

Boolean/Phrase

Search modes -

Boolean/Phrase

Search modes -

Boolean/Phrase
Interface - EBSCOhost

Research Databases

Search Screen - Advanced

Search

Database - PsycINFO

Interface - EBSCOhost

Research Databases

Search Screen - Advanced

Search

Database - PsycINFO

Interface - EBSCOhost

Research Databases

Search Screen - Advanced

Search

Database - PsycINFO

Interface - EBSCOhost

Research Databases

Search Screen - Advanced

Search

Database - PsycINFO

Interface - EBSCOhost

Research Databases

Search Screen - Advanced

Search

Database - PsycINFO

Interface - EBSCOhost

Research Databases

Search Screen - Advanced

Search

Database - PsycINFO

Interface - EBSCOhost

Research Databases

Search Screen - Advanced

Search

Database - PsycINFO

Interface - EBSCOhost

Research Databases

Search Screen - Advanced

Search

Database - PsycINFO

Display

Display

Display

Display

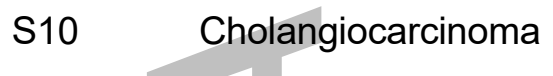

Hepatology

This article is protected by copyright. All rights reserved. 


\begin{tabular}{|c|c|c|c|c|}
\hline S9 & cirrhosis & $\begin{array}{l}\text { Search modes - } \\
\text { Boolean/Phrase }\end{array}$ & $\begin{array}{l}\text { Interface - EBSCOhost } \\
\text { Research Databases } \\
\text { Search Screen - Advanced } \\
\text { Search } \\
\text { Database - PsycINFO }\end{array}$ & Display \\
\hline S8 & HBV & $\begin{array}{l}\text { Search modes - } \\
\text { Boolean/Phrase }\end{array}$ & $\begin{array}{l}\text { Interface - EBSCOhost } \\
\text { Research Databases } \\
\text { Search Screen - Advanced } \\
\text { Search } \\
\text { Database - PsycINFO }\end{array}$ & Display \\
\hline S7 & $\mathrm{HC}$ & $\begin{array}{l}\text { Search modes - } \\
\text { Boolean/Phrase }\end{array}$ & $\begin{array}{l}\text { Interface - EBSCOhost } \\
\text { Research Databases } \\
\text { Search Screen - Advanced } \\
\text { Search } \\
\text { Database - PsycINFO }\end{array}$ & Display \\
\hline S6 & "hepatitis b" & $\begin{array}{l}\text { Search modes - } \\
\text { Boolean/Phrase }\end{array}$ & $\begin{array}{l}\text { Interface - EBSCOhost } \\
\text { Research Databases } \\
\text { Search Screen - Advanced } \\
\text { Search } \\
\text { Database - PsycINFO }\end{array}$ & Display \\
\hline S5 & "hepatitis c" & $\begin{array}{l}\text { Search modes - } \\
\text { Boolean/Phrase }\end{array}$ & $\begin{array}{l}\text { Interface - EBSCOhost } \\
\text { Research Databases } \\
\text { Search Screen - Advanced } \\
\text { Search } \\
\text { Database - PsycINFO }\end{array}$ & Display \\
\hline S4 & DE "Hepatitis" & $\begin{array}{l}\text { Search modes - } \\
\text { Boolean/Phrase }\end{array}$ & $\begin{array}{l}\text { Interface - EBSCOhost } \\
\text { Research Databases } \\
\text { Search Screen - Advanced } \\
\text { Search } \\
\text { Database - PsycINFO }\end{array}$ & Display \\
\hline S3 & DE "Cirrhosis (Liver)" & $\begin{array}{l}\text { Search modes - } \\
\text { Boolean/Phrase }\end{array}$ & $\begin{array}{l}\text { Interface - EBSCOhost } \\
\text { Research Databases } \\
\text { Search Screen - Advanced } \\
\text { Search } \\
\text { Database - PsycINFO }\end{array}$ & Display \\
\hline $\mathrm{S} 2$ & hcc & $\begin{array}{l}\text { Search modes - } \\
\text { Boolean/Phrase }\end{array}$ & $\begin{array}{l}\text { Interface - EBSCOhost } \\
\text { Research Databases } \\
\text { Search Screen - Advanced } \\
\text { Search } \\
\text { Database - PsycINFO }\end{array}$ & Display \\
\hline
\end{tabular}


http://web.a.ebscohost.com/ehost/searchhistory/PrintSearchHistory?sid=... Page 61 of 76



This article is protected by copyright. All rights reserved. Hepatology
Search modes -

Boolean/Phrase
Interface - EBSCOhost

Search Screen - Advanced

Search

Database - PsycINFO 


\begin{tabular}{|c|c|c|c|c|}
\hline & & \multicolumn{3}{|c|}{ Monday, May 01, 2017 10:06:10 AM } \\
\hline \# & Query & Limiters/Expanders & Last Run Via & Results \\
\hline S88 & $\begin{array}{l}\text { (S61 AND S87) AND LA } \\
\text { english) }\end{array}$ & $\begin{array}{l}\text { Search modes - } \\
\text { Boolean/Phrase }\end{array}$ & $\begin{array}{l}\text { Interface - EBSCOhost } \\
\text { Research Databases } \\
\text { Search Screen - Advanced } \\
\text { Search } \\
\text { Database - PsycINFO }\end{array}$ & 320 \\
\hline S87 & $\begin{array}{l}\text { S62 OR S63 OR S64 OR } \\
\text { S65 OR S66 OR S67 OR } \\
\text { S68 OR S69 OR S70 OR } \\
\text { S71 OR S72 OR S73 OR } \\
\text { S74 OR S75 OR S76 OR } \\
\text { S77 OR S78 OR S79 OR } \\
\text { S80 OR S81 OR S82 OR } \\
\text { S83 OR S84 OR S85 OR } \\
\text { S86 }\end{array}$ & $\begin{array}{l}\text { Search modes - } \\
\text { Boolean/Phrase }\end{array}$ & $\begin{array}{l}\text { Interface - EBSCOhost } \\
\text { Research Databases } \\
\text { Search Screen - Advanced } \\
\text { Search } \\
\text { Database - PsycINFO }\end{array}$ & Display \\
\hline S86 & $\begin{array}{l}\text { (patient n10 reported) } \\
\text { AND (outcome* or } \\
\text { satisfaction* or measure* }^{*} \\
\text { or "quality of life") }\end{array}$ & $\begin{array}{l}\text { Search modes - } \\
\text { Boolean/Phrase }\end{array}$ & $\begin{array}{l}\text { Interface - EBSCOhost } \\
\text { Research Databases } \\
\text { Search Screen - Advanced } \\
\text { Search } \\
\text { Database - PsycINFO }\end{array}$ & Display \\
\hline S85 & $\begin{array}{l}\text { "health related quality of } \\
\text { life" }\end{array}$ & $\begin{array}{l}\text { Search modes - } \\
\text { Boolean/Phrase }\end{array}$ & $\begin{array}{l}\text { Interface - EBSCOhost } \\
\text { Research Databases } \\
\text { Search Screen - Advanced } \\
\text { Search } \\
\text { Database - PsycINFO }\end{array}$ & Display \\
\hline S84 & QOL & $\begin{array}{l}\text { Search modes - } \\
\text { Boolean/Phrase }\end{array}$ & $\begin{array}{l}\text { Interface - EBSCOhost } \\
\text { Research Databases } \\
\text { Search Screen - Advanced } \\
\text { Search } \\
\text { Database - PsycINFO }\end{array}$ & Display \\
\hline S83 & HRQOL & $\begin{array}{l}\text { Search modes - } \\
\text { Boolean/Phrase }\end{array}$ & $\begin{array}{l}\text { Interface - EBSCOhost } \\
\text { Research Databases } \\
\text { Search Screen - Advanced } \\
\text { Search } \\
\text { Database - PsycINFO }\end{array}$ & Display \\
\hline S82 & DE "Quality of Life" & $\begin{array}{l}\text { Search modes - } \\
\text { Boolean/Phrase } \\
\text { Hepatology }\end{array}$ & $\begin{array}{l}\text { Interface - EBSCOhost } \\
\text { Research Databases }\end{array}$ & Display \\
\hline
\end{tabular}

This article is protected by copyright. All rights reserved.

\section{Limiters/Expander \\ Search modes - Boolean/Phrase}

Search modes -

Search modes AND (outcome* or satisfaction* or measure 
Search Screen - Advanced

Search

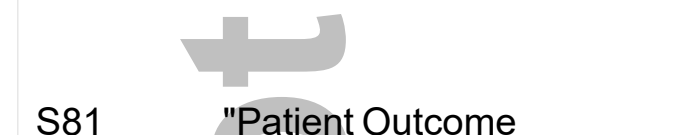

S81

"Patient Outcome

Assessment"

Search modes -

Database - PsycINFO

Boolean/Phrase

Interface - EBSCOhost

Display

Research Databases

Search Screen - Advanced

Search



Search modes -

Search modes -

S80 EuroQOL-5D

Boolean/Phrase

Search modes -

Boolean/Phrase

Search modes -

Boolean/Phrase

Search modes -

Boolean/Phrase

Search modes -

Boolean/Phrase

Search modes -

Boolean/Phrase

Interface - EBSCOhost

Research Databases

Search Screen - Advanced

Search

Database - PsycINFO

Interface - EBSCOhost

Display

Research Databases

Search Screen - Advanced

Search

Database - PsycINFO

Interface - EBSCOhost

Display

Research Databases

Search Screen - Advanced

Search

Database - PsycINFO

Interface - EBSCOhost

Display

Research Databases

Search Screen - Advanced

Search

Database - PsycINFO

Interface - EBSCOhost

Display

Research Databases

Search Screen - Advanced

Search

Database - PsycINFO

Interface - EBSCOhost

Display

Research Databases

Search Screen - Advanced

Search

Database - PsycINFO

Interface - EBSCOhost

Display

Research Databases

Search Screen - Advanced

Hepatology

This article is protected by copyright. All rights reserved. 


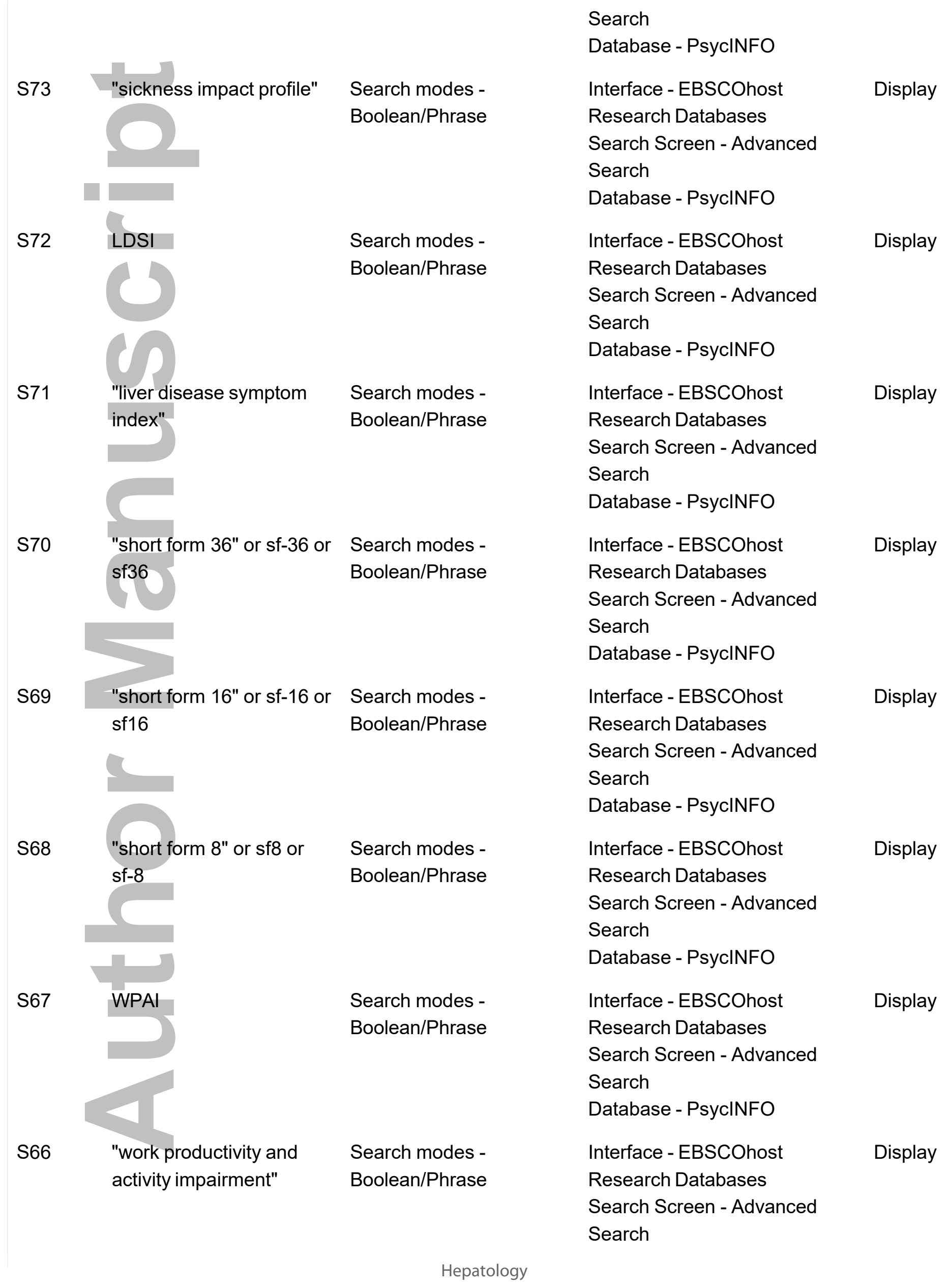

This article is protected by copyright. All rights reserved. 


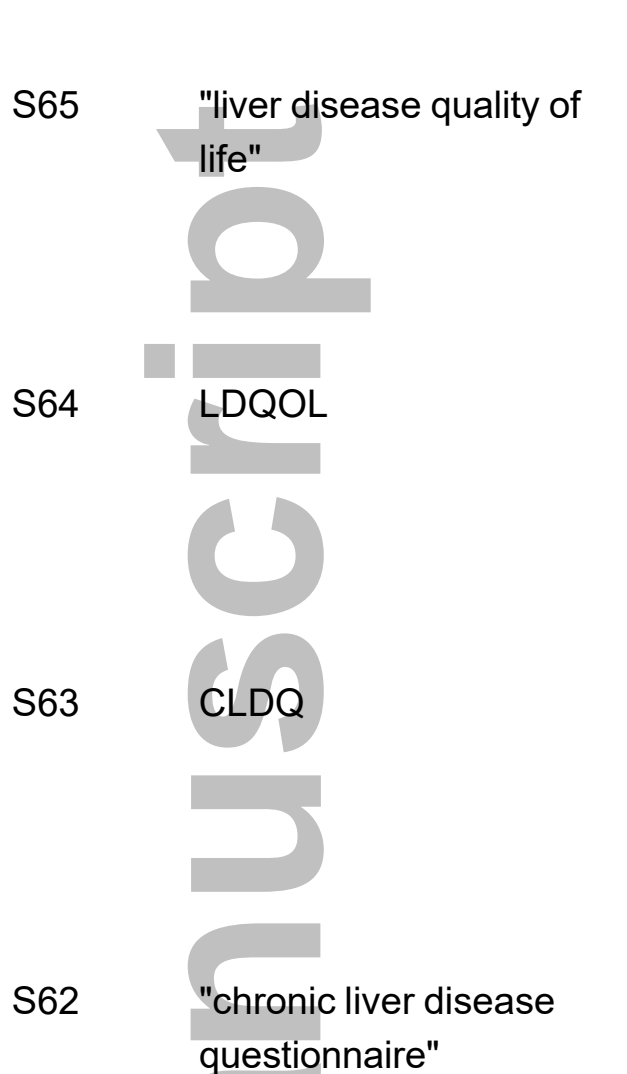

Search modes -

Boolean/Phrase

Search modes -

Boolean/Phrase

Search modes -

Boolean/Phrase

Search modes -

Boolean/Phrase

S61

(S45 OR S46 OR S47

OR S48 OR S49 OR S50

OR S51 OR S52 OR S53

OR S54 OR S55 OR S56

OR S57 OR S58 OR S59

OR S60)

S60

"liver disease ${ }^{* "}$

Search modes -

Boolean/Phrase

Search modes -

Boolean/Phrase

liver"

S58

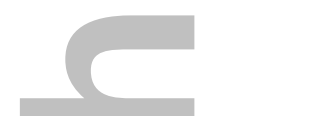

Search modes -

Boolean/Phrase

S59 (non-alcoholic or nonalcoholic ) AND "fatty

Search modes -

Database - PsycINFO

Interface - EBSCOhost

Display

Research Databases

Search Screen - Advanced

Search

Database - PsycINFO

Interface - EBSCOhost

Research Databases

Search Screen - Advanced

Search

Database - PsycINFO

Interface - EBSCOhost

Display

Research Databases

Search Screen - Advanced

Search

Database - PsycINFO

Interface - EBSCOhost

Display

Research Databases

Search Screen - Advanced

Search

Database - PsycINFO

Interface - EBSCOhost

Display

Research Databases

Search Screen - Advanced

Search

Database - PsycINFO

Display

Display

Interface - EBSCOhost

Display

Research Databases

Search Screen - Advanced

Search

Database - PsycINFO

Interface - EBSCOhost

Display

Research Databases

Search Screen - Advanced

Search

Database - PsycINFO

Interface - EBSCOhost

Display

Boolean/Phrase

Research Databases

Search Screen - Advanced

Search

Hepatology

This article is protected by copyright. All rights reserved. 
S57

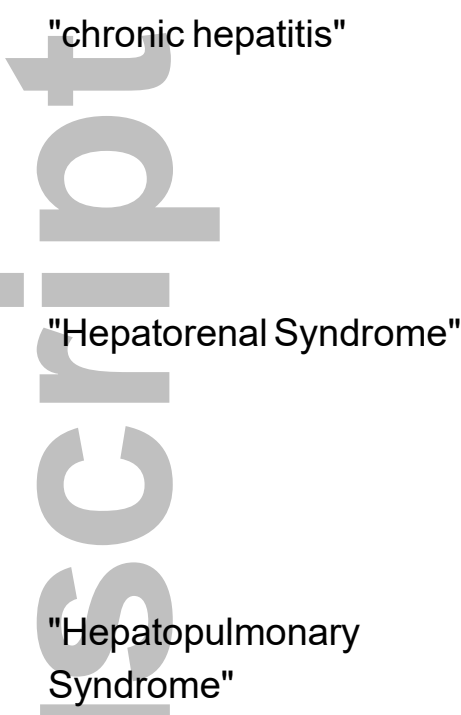

S55

S56

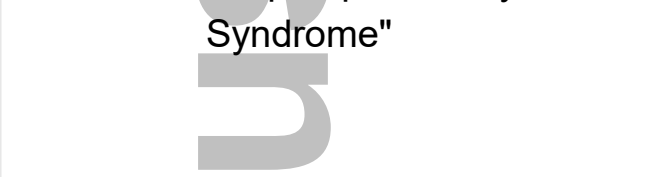

S53

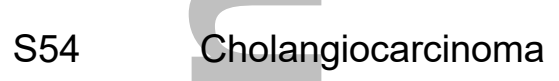

S52

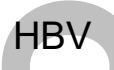

S51

S50
Search modes -
Boolean/Phrase

Search modes -

Boolean/Phrase

Search modes -

Boolean/Phrase

Search modes -

Boolean/Phrase

Search modes -

Boolean/Phrase

Search modes -

Boolean/Phrase

Search modes -

Boolean/Phrase

Search modes -

Boolean/Phrase
Database - PsycINFO

Interface - EBSCOhost

Research Databases

Search Screen - Advanced

Search

Database - PsycINFO

Interface - EBSCOhost

Research Databases

Search Screen - Advanced

Search

Database - PsycINFO

Interface - EBSCOhost

Research Databases

Search Screen - Advanced

Search

Database - PsycINFO

Interface - EBSCOhost

Research Databases

Search Screen - Advanced

Search

Database - PsycINFO

Interface - EBSCOhost

Research Databases

Search Screen - Advanced

Search

Database - PsycINFO

Interface - EBSCOhost

Research Databases

Search Screen - Advanced

Search

Database - PsycINFO

Interface - EBSCOhost

Research Databases

Search Screen - Advanced

Search

Database - PsycINFO

Interface - EBSCOhost

Research Databases

Search Screen - Advanced

Search

Database - PsycINFO

Display

Display

Display

Display

Display

Display

Display 


\begin{tabular}{|c|c|c|c|c|}
\hline S49 & "hepatitis c" & $\begin{array}{l}\text { Search modes - } \\
\text { Boolean/Phrase }\end{array}$ & $\begin{array}{l}\text { Interface - EBSCOhost } \\
\text { Research Databases } \\
\text { Search Screen - Advanced } \\
\text { Search } \\
\text { Database - PsycINFO }\end{array}$ & Display \\
\hline S48 & DE "Hepatitis" & $\begin{array}{l}\text { Search modes - } \\
\text { Boolean/Phrase }\end{array}$ & $\begin{array}{l}\text { Interface - EBSCOhost } \\
\text { Research Databases } \\
\text { Search Screen - Advanced } \\
\text { Search } \\
\text { Database - PsycINFO }\end{array}$ & Display \\
\hline S47 & DE "Cirrhosis (Liver)" & $\begin{array}{l}\text { Search modes - } \\
\text { Boolean/Phrase }\end{array}$ & $\begin{array}{l}\text { Interface - EBSCOhost } \\
\text { Research Databases } \\
\text { Search Screen - Advanced } \\
\text { Search } \\
\text { Database - PsycINFO }\end{array}$ & Display \\
\hline S46 & & $\begin{array}{l}\text { Search modes - } \\
\text { Boolean/Phrase }\end{array}$ & $\begin{array}{l}\text { Interface - EBSCOhost } \\
\text { Research Databases } \\
\text { Search Screen - Advanced } \\
\text { Search } \\
\text { Database - PsycINFO }\end{array}$ & Display \\
\hline S45 & $\begin{array}{l}\text { "hepatocellular } \\
\text { Carcinoma" }\end{array}$ & $\begin{array}{l}\text { Search modes - } \\
\text { Boolean/Phrase }\end{array}$ & $\begin{array}{l}\text { Interface - EBSCOhost } \\
\text { Research Databases } \\
\text { Search Screen - Advanced } \\
\text { Search } \\
\text { Database - PsycINFO }\end{array}$ & Display \\
\hline S44 & $\begin{array}{l}\text { (S17 AND S43) AND LA } \\
\text { english) }\end{array}$ & $\begin{array}{l}\text { Search modes - } \\
\text { Boolean/Phrase }\end{array}$ & $\begin{array}{l}\text { Interface - EBSCOhost } \\
\text { Research Databases } \\
\text { Search Screen - Advanced } \\
\text { Search } \\
\text { Database - PsycINFO }\end{array}$ & 320 \\
\hline S43 & $\begin{array}{l}\text { S18 OR S19 OR S20 OR } \\
\text { S21 OR S22 OR S23 OR } \\
\text { S24 OR S25 OR S26 OR } \\
\text { S27 OR S28 OR S29 OR } \\
\text { S30 OR S31 OR S32 OR } \\
\text { S33 OR S34 OR S35 OR } \\
\text { S36 OR S37 OR S38 OR } \\
\text { S39 OR S40 OR S41 OR } \\
\text { S42 }\end{array}$ & $\begin{array}{l}\text { Search modes - } \\
\text { Boolean/Phrase }\end{array}$ & $\begin{array}{l}\text { Interface - EBSCOhost } \\
\text { Research Databases } \\
\text { Search Screen - Advanced } \\
\text { Search } \\
\text { Database - PsycINFO }\end{array}$ & 66,002 \\
\hline S42 & $\begin{array}{l}\text { (patient n10 reported) } \\
\text { AND (outcome* or } \\
\text { satisfaction* or measure* }^{*}\end{array}$ & $\begin{array}{r}\text { Search modes - } \\
\text { Boolean/Phrase } \\
\text { Hepatol }\end{array}$ & $\begin{array}{l}\text { Interface - EBSCOhost } \\
\text { Research Databases } \\
\text { Search Screen - Advanced }\end{array}$ & Display \\
\hline
\end{tabular}

This article is protected by copyright. All rights reserved. 


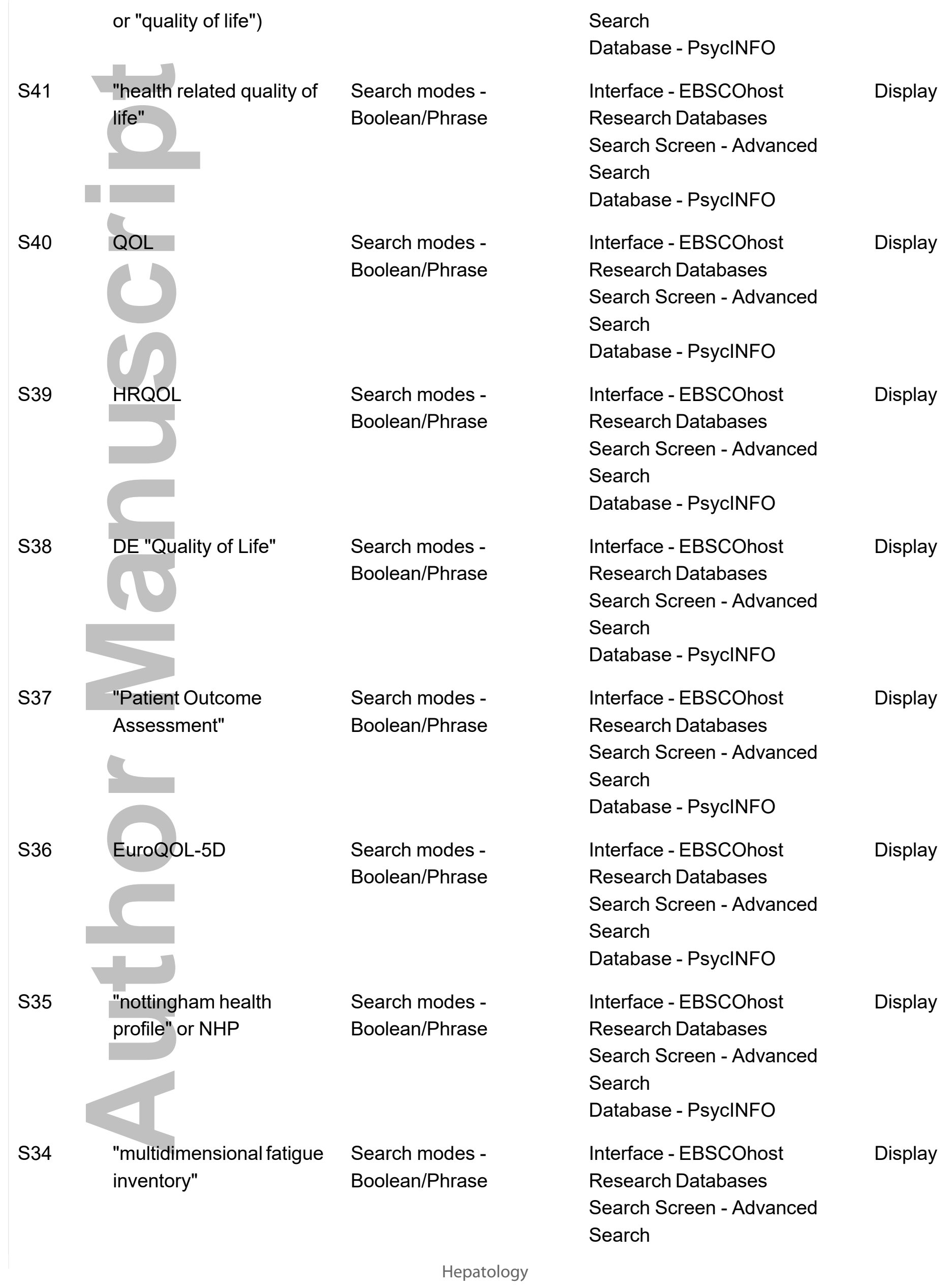

This article is protected by copyright. All rights reserved. 
2

3

4

5

6

7

\section{S33} "multi-dimensional fatigue inventory"

S32

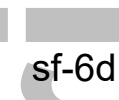

S31

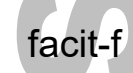

S30

S29
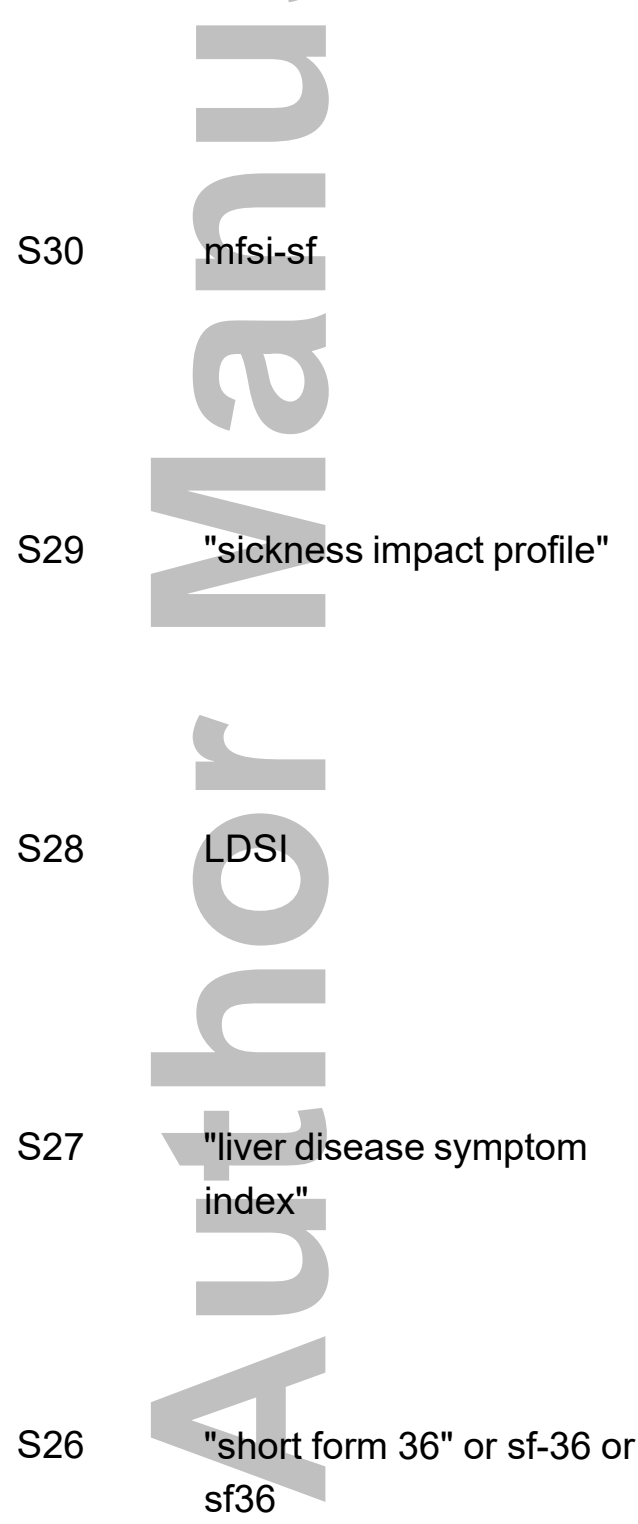

Search modes -

Boolean/Phrase

Search modes -

Boolean/Phrase

Search modes -

Boolean/Phrase

Search modes -

Boolean/Phrase

Search modes -

Boolean/Phrase

Search modes -

Boolean/Phrase

Search modes -

Boolean/Phrase
Database - PsycINFO

Interface - EBSCOhost

Research Databases

Search Screen - Advanced

Search

Database - PsycINFO

Interface - EBSCOhost

Research Databases

Search Screen - Advanced

Search

Database - PsycINFO

Interface - EBSCOhost

Research Databases

Search Screen - Advanced

Search

Database - PsycINFO

Interface - EBSCOhost

Research Databases

Search Screen - Advanced

Search

Database - PsycINFO

Interface - EBSCOhost

Research Databases

Search Screen - Advanced

Search

Database - PsycINFO

Interface - EBSCOhost

Research Databases

Search Screen - Advanced

Search

Database - PsycINFO

Interface - EBSCOhost

Research Databases

Search Screen - Advanced

Search

Database - PsycINFO

Interface - EBSCOhost

Display

Display

Display

Display

Display

Display

Display

Research Databases

Search Screen - Advanced

Search

Database - PsycINFO

Hepatology 




Search modes -

Boolean/Phrase

Search modes -

Boolean/Phrase

Search modes -

Boolean/Phrase

Search modes -

Boolean/Phrase

Search modes -

Boolean/Phrase

Search modes -

Boolean/Phrase

Search modes -

Boolean/Phrase

Search modes -

Boolean/Phrase
Interface - EBSCOhost

Research Databases

Search Screen - Advanced

Search

Database - PsycINFO

Interface - EBSCOhost

Research Databases

Search Screen - Advanced

Search

Database - PsycINFO

Interface - EBSCOhost

Research Databases

Search Screen - Advanced

Search

Database - PsycINFO

Interface - EBSCOhost

Research Databases

Search Screen - Advanced

Search

Database - PsycINFO

Interface - EBSCOhost

Research Databases

Search Screen - Advanced

Search

Database - PsycINFO

Interface - EBSCOhost

Research Databases

Search Screen - Advanced

Search

Database - PsycINFO

Interface - EBSCOhost

Research Databases

Search Screen - Advanced

Search

Database - PsycINFO

Interface - EBSCOhost

Research Databases

Search Screen - Advanced

Search

Database - PsycINFO

Display

Display

Display

Display

Display

Display

Display

Display

$$
\text { questionnaire" }
$$




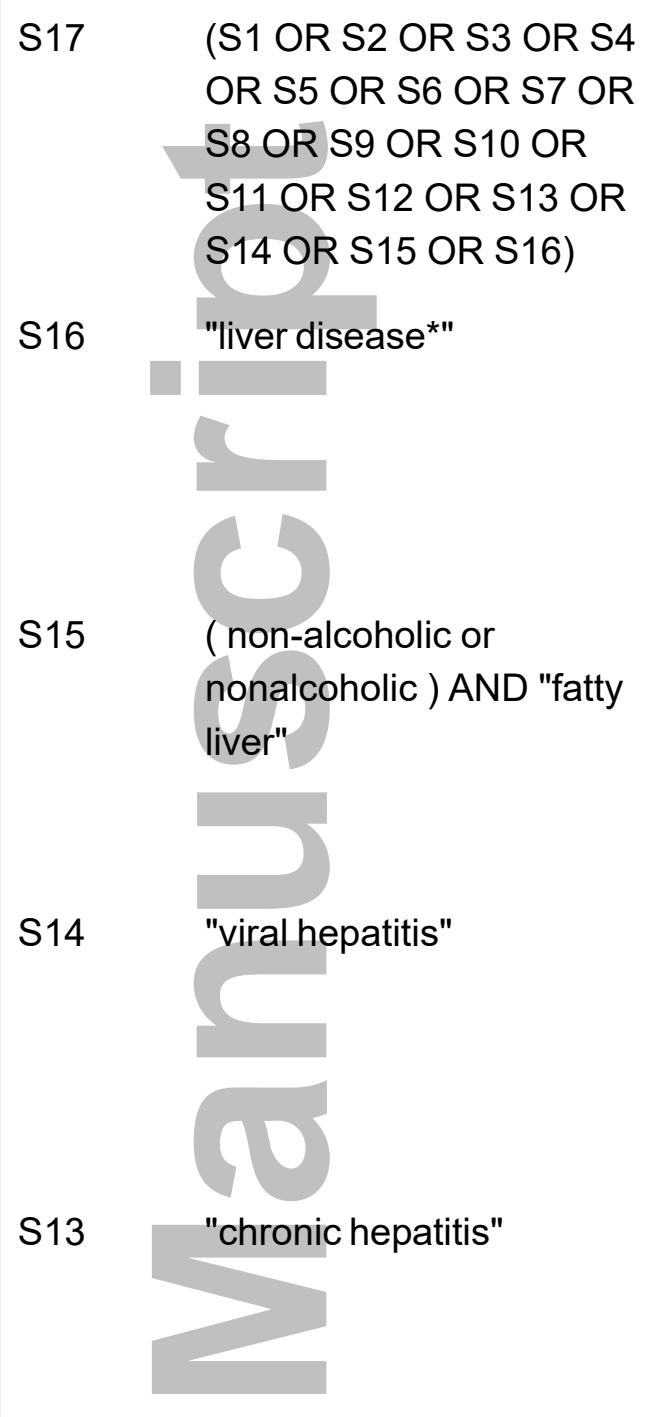

Search modes -

Boolean/Phrase

S8 OR S9 OR S10 OR

S11 OR S12 OR S13 OR

S14 OR S15 OR S16)

Search modes -

Boolean/Phrase

Search modes -

Boolean/Phrase

Search modes -

Boolean/Phrase

Search modes -

Boolean/Phrase

S12 "Hepatorenal Syndrome"

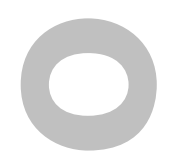

Search modes -

Boolean/Phrase

Search modes -

Boolean/Phrase

Search modes -

Boolean/Phrase
Interface - EBSCOhost

Research Databases

Search Screen - Advanced

Search

Database - PsycINFO

Interface - EBSCOhost

Research Databases

Search Screen - Advanced

Search

Database - PsycINFO

Interface - EBSCOhost

Research Databases

Search Screen - Advanced

Search

Database - PsycINFO

Interface - EBSCOhost

Research Databases

Search Screen - Advanced

Search

Database - PsycINFO

Interface - EBSCOhost

Research Databases

Search Screen - Advanced

Search

Database - PsycINFO

Interface - EBSCOhost

Research Databases

Search Screen - Advanced

Search

Database - PsycINFO

Interface - EBSCOhost

Research Databases

Search Screen - Advanced

Search

Database - PsycINFO

Interface - EBSCOhost

Research Databases

Search Screen - Advanced

Search

Database - PsycINFO

\begin{tabular}{|l||}
\hline Display \\
\hline Display \\
\hline Display \\
\hline Display \\
\hline Display
\end{tabular}

\begin{tabular}{|l||}
\hline Display \\
\hline Display \\
\hline Display \\
\hline Display \\
\hline Display
\end{tabular}

\begin{tabular}{|l||}
\hline Display \\
\hline Display \\
\hline Display \\
\hline Display \\
\hline Display
\end{tabular}

\begin{tabular}{|l|}
\hline Display \\
\hline Display \\
\hline Display \\
\hline Display \\
\hline Display
\end{tabular}

\begin{tabular}{|l|}
\hline Display \\
\hline Display \\
\hline Display \\
\hline Display \\
\hline Display
\end{tabular}

$\begin{array}{lll}\text { S10 Cholangiocarcinoma } & \text { Search modes - } & \text { Interface - EBSCOhost } \\ \text { Boolean/Phrase } & \text { Research Databases } \\ & \text { Search Screen - Advanced } \\ & \text { Search } \\ & \text { Database - PsyclNFO }\end{array}$

Hepatology

This article is protected by copyright. All rights reserved. 




\begin{abstract}
Search modes -
Boolean/Phrase
\end{abstract}

Search modes -

Boolean/Phrase

Search modes -

Boolean/Phrase

Search modes -

Boolean/Phrase

Search modes -

Boolean/Phrase

S4 DE "Hepatitis"

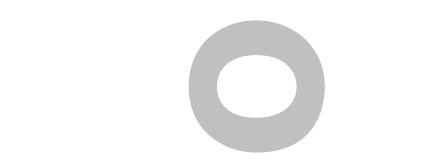

S3 DE "Cirrhosis (Liver)"

S2
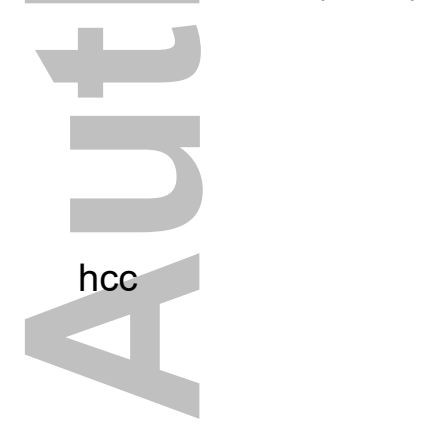

Search modes -

Boolean/Phrase

Search modes -

Boolean/Phrase

Search modes -

Boolean/Phrase
Interface - EBSCOhost

Research Databases

Search Screen - Advanced

Search

Database - PsycINFO

Interface - EBSCOhost

Research Databases

Search Screen - Advanced

Search

Database - PsycINFO

Interface - EBSCOhost

Research Databases

Search Screen - Advanced

Search

Database - PsycINFO

Interface - EBSCOhost

Display

Research Databases

Search Screen - Advanced

Search

Database - PsycINFO

Interface - EBSCOhost

Research Databases

Search Screen - Advanced

Search

Database - PsycINFO

Interface - EBSCOhost

Research Databases

Search Screen - Advanced

Search

Database - PsycINFO

Interface - EBSCOhost

Research Databases

Search Screen - Advanced

Search

Database - PsycINFO

Interface - EBSCOhost

Research Databases

Search Screen - Advanced

Search

Database - PsycINFO

Display

Display

Display

Display

Display

Display 
http://web.a.ebscohost.com/ehost/searchhistory/PrintSearchHistory?sid=... Hepatology

Interface - EBSCOhost

Research Databases

Boolean/Phrase

Search Screen - Advanced

Search

Database - PsycINFO

Hepatology

This article is protected by copyright. All rights reserved.

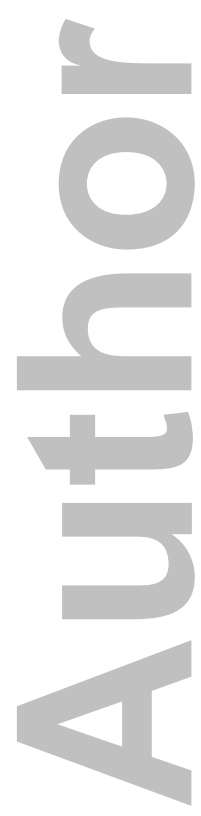




\section{COCHRANE}

Description:

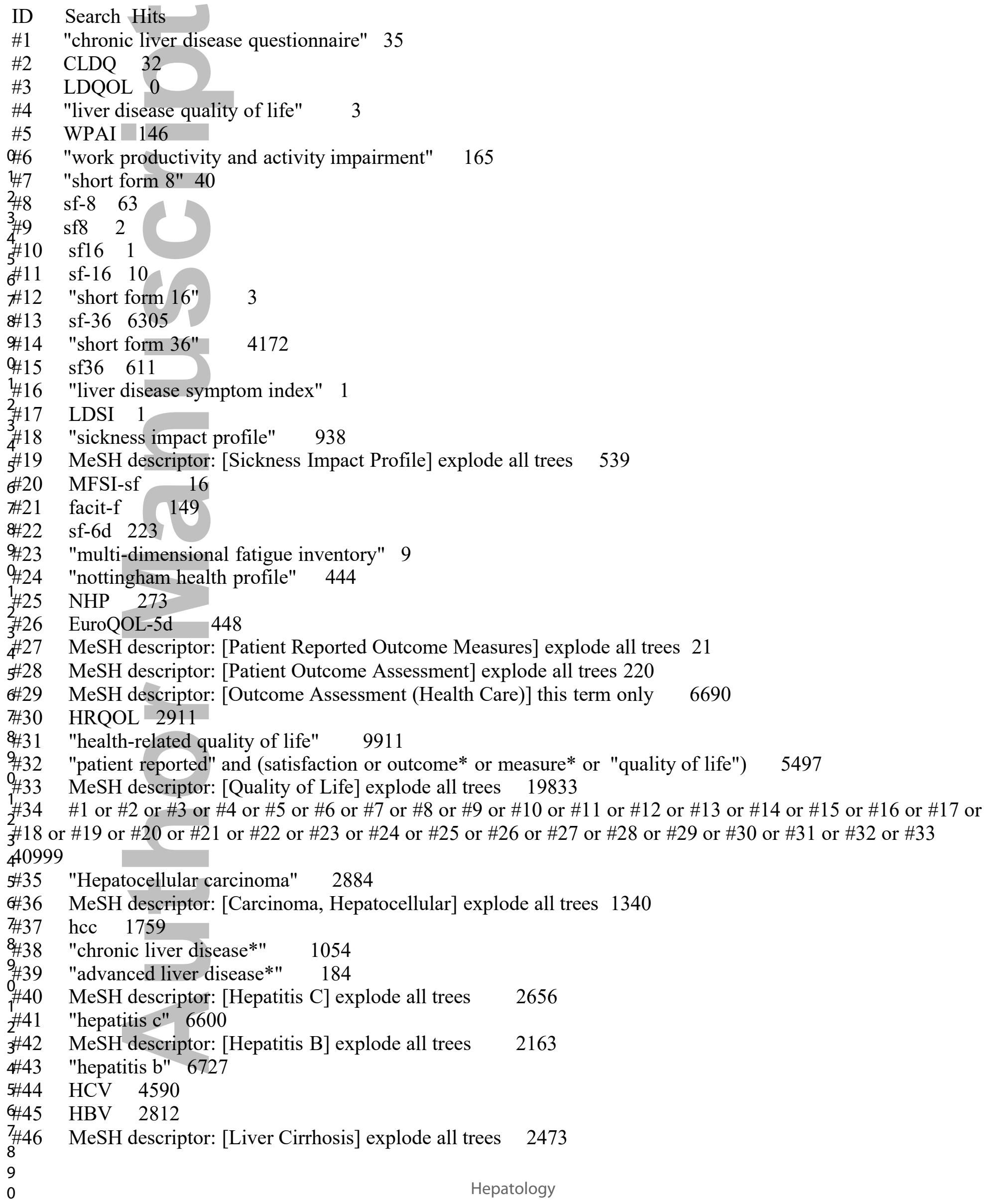









\section{Pubmed Search}

\section{Disease Concept Block}

"Carcinoma, Hepatocellular"[Mesh] OR "hepatocellular carcinoma"[tw] OR hcc[tw] OR "Liver Diseases, Alcoholic"[Mesh] OR "chronic liver disease"[tiab] OR "chronic liver diseases"[tiab] OR "advanced liver disease"[tiab] OR "advanced liver diseases"[tiab] OR "Hepatitis B"[Mesh] OR "Hepatitis C"[Mesh] OR "hepatitis b"[tw] OR "hepatitis c"[tw] OR hcv[tw] OR hbv[tw] OR "Liver Cirrhosis"[Mesh] OR cirrhosis[tw] OR "Non-alcoholic Fatty Liver Disease"[Mesh] OR "Non-alcoholic Fatty Liver Disease"[tw] OR "Cholangiocarcinoma"[Mesh] OR "Cholangiocarcinoma"[tw] OR "Hepatopulmonary Syndrome"[Mesh] OR "Hepatopulmonary Syndrome"[tw] OR "Hepatorenal Syndrome"[Mesh] OR "Hepatorenal Syndrome"[tw] OR "Hepatitis, Chronic"[Mesh:noexp] OR "Hepatitis, Viral, Human"[Mesh:noexp] OR (hepatitis[tiab] and (chronic[tiab] or viral[tiab]))

\section{AND}

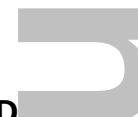

Patient Reported Outcome Bloc

"chronic liver disease questionnaire"[tw] OR CLDQ[tw] OR LDQOL[tw] OR "work productivity and activity impairment"[tw] OR "WPAI"[tw] OR "short form 8"[tw] OR sf-8[tw] OR sf8[tw] OR sf-16[tw] OR sf16[tw] OR sf-36[tw] OR "short form 36"[tw] OR "liver disease symptom index"[tw] OR LDSI[tw] OR sf36[tw] OR "sickness impact profile"[tw] OR mfsi-sf[tw] OR facit-f[tw] OR sf-6d[tw] OR "multi-dimensional fatigue inventory"[tw] OR MFSI-SF[tw] OR "nottingham health profile"[tw] OR EuroQOL-5D[tw] OR "sickness impact profile"[tw] OR SIP[tw] OR" patient reported outcome measures"[mh] OR patient outcome assessment[mh] OR "patient satisfaction"[tw] OR "patient reported"[tw] OR "quality of life"[tiab] OR "quality of life"[mesh] OR "Outcome Assessment (Health Care)"[Majr] OR HRQOL[tw] OR "patient reported outcomes"[tw] OR "health-related quality of life"[tw] OR QOL[tw] OR "quality of life"[tw]

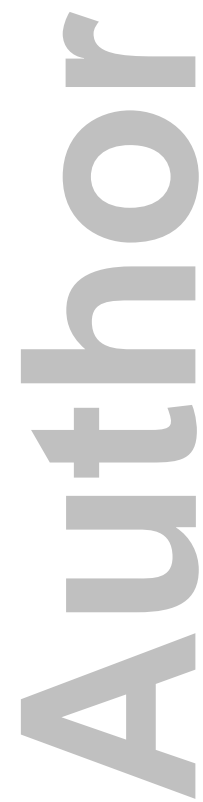

